\title{
MANAJEMEN PENDIDIKAN DALAM MENGASUH SANTRI GANGGUAN JIWA DI PONDOK PESANTREN AL-QODIR CANGKRINGAN SLEMAN YOGYAKARTA
}
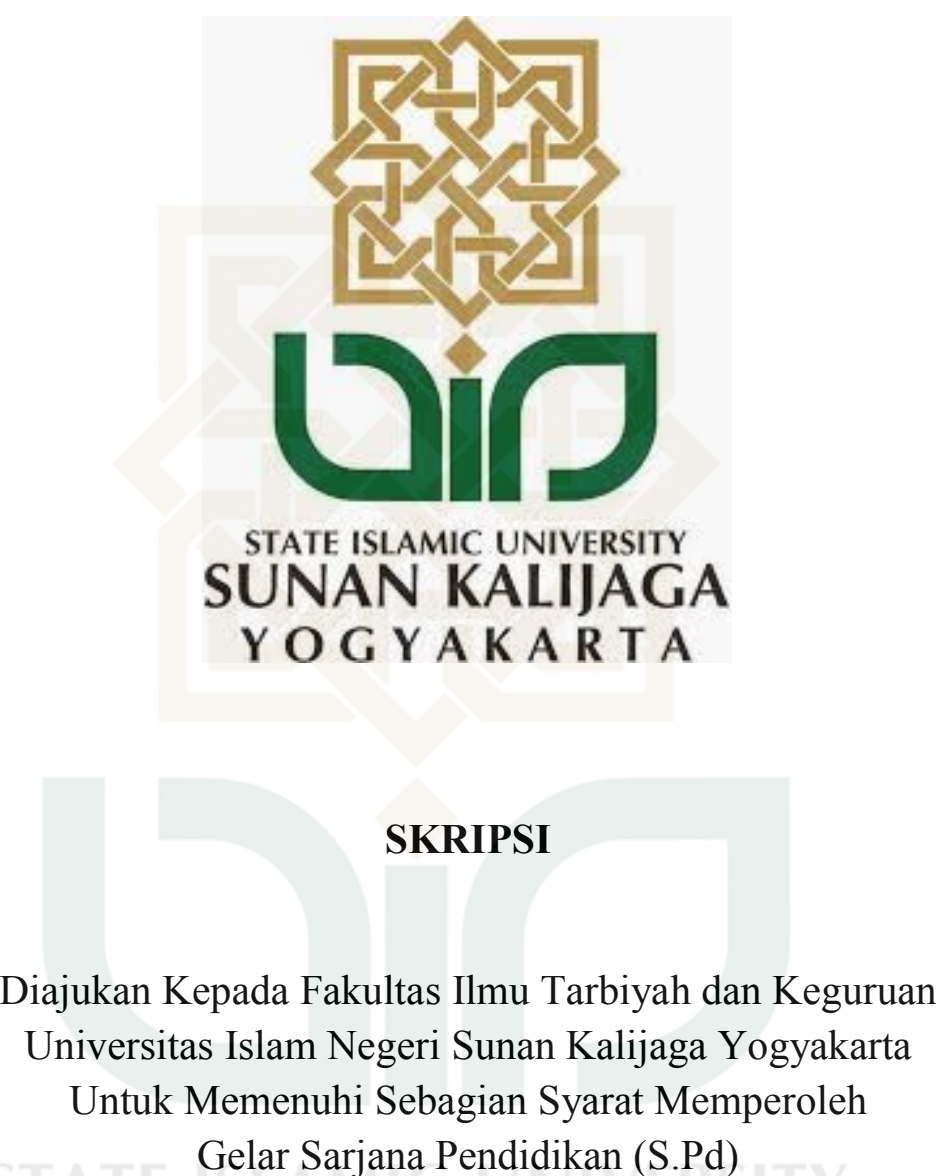

Disusun Oleh:

Arif Musafa

NIM: 13490032

\author{
PROGRAM STUDI MANAJEMEN PENDIDIKAN ISLAM \\ FAKULTAS ILMU TARBIYAH DAN KEGURUAN \\ UNIVERSITAS ISLAM NEGERI SUNAN KALIJAGA \\ YOGYAKARTA \\ 2017
}




\section{SURAT PERNYATAAN KEASLIAN}

Yang bertanda tangan di bawah ini :

$\begin{array}{ll}\text { Nama } & : \text { Arif Musafa } \\ \text { NIM } & : 13490032 \\ \text { Program Studi } & : \text { Manajemen Pendidikan Islam } \\ \text { Fakultas } & : \text { Ilmu Tarbiyah dan Keguruan } \\ & \text { UIN Sunan Kalijaga Yogyakarta }\end{array}$

Menyatakan dengan sesungguhnya bahwa Skripsi saya ini adalah asli hasil penelitian peneliti sendiri bukan plagiasi karya orang lain kecuali pada bagianbagian yang dirujuk sumbernya.

Yogyakarta, 7 Oktober 2017

Yang Menyatakan

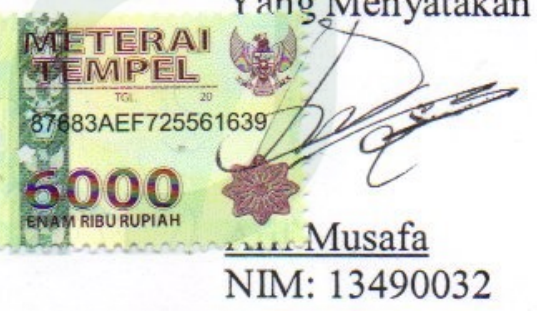




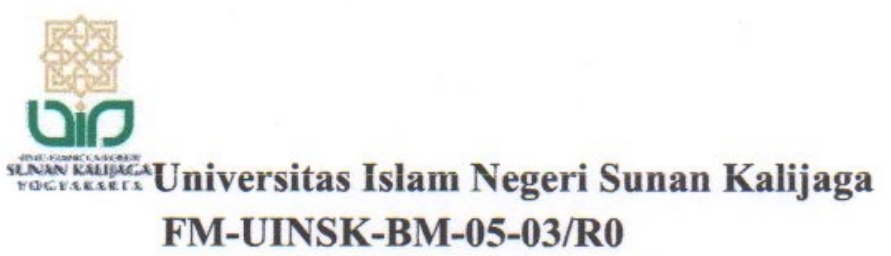

\section{SURAT PERSETUJUAN SKRIPSI}

Hal : Skripsi Saudara Arif Musafa

Lamp : 3 Eksemplar

Kepada:

Yth. Dekan Fakultas Ilmu Tarbiyah dan Keguruan

UIN Sunan Kalijaga Yogyakarta

di Yogyakarta

Assalammu'alaikum $\mathrm{Wr}$. Wb.

Setelah membaca, meneliti, memberikan petunjuk dan mengoreksi serta mengadakan pembimbingan seperlunya, maka kami selaku Pembimbing berpendapat bahwa Skripsi Saudara :

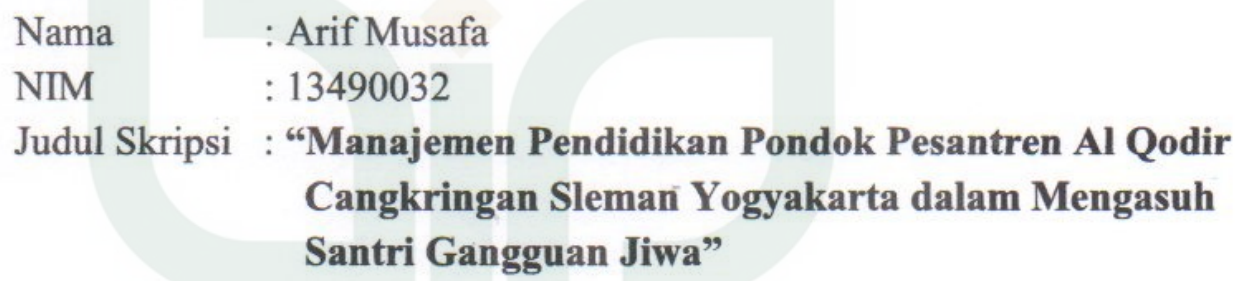

Sudah dapat diajukan kepada Program Studi Manajemen Pendidikan Islam Fakultas Ilmu Tarbiyah dan Keguruan UIN Sunan Kalijaga Yogyakarta sebagai salah satu syarat untuk memperoleh gelar Sarjana Strata Satu Pendidikan.

Dengan ini kami mengharap agar Skripsi Saudara tersebut di atas dapat segera dimunaqosyahkan. Atas perhatiannya kami ucapkan terimakasih.

Wassalammu'alaikum Wr. Wb.

Yogyakarta, 26 Oktober 2017

Pembimbing Skripsi,

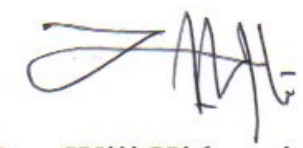

Dra. Wiji Hidayati, M.Ag NIP. 196505231991032010 


\section{Universitas Islam Negeri Sunan Kalijaga}

FM-UINSK-BM-05-03/R0

\section{SURAT PERSETUJUAN PERBAIKAN SKRIPSI}

Kepada

Yth. Dekan Fakultas Ilmu Tarbiyah Dan Keguruan

UIN Sunan Kalijaga Yogyakarta

Di Yogyakarta

Assalamu'alaikum, $W r$. Wb.

Setelah melaksanakan munaqasyah pada hari Jum'at 3 November 2017 dan Skripsi mahasiswa tersebut dibawah ini dinyatakan lulus dengan perbaikan, maka setelah membaca, meneliti, dan mengoreksi perbaikan seperlunya, kami selaku Konsultan berpendapat bahwa Skripsi Saudara:

$\begin{array}{ll}\text { Nama } & : \text { Arif Musafa } \\ \text { NIM } & : 13490032 \\ \text { Judul Skripsi } & : \text { Manajemen Pendidikan dalam Mengasuh Santri } \\ & \text { Gangguan Jiwa di Pondok Pesantren Al Qodir } \\ & \text { Cangkringan Sleman Yogyakarta }\end{array}$

sudah dapat diajukan kembali kepada Program/Studi Manajemen Pendidikan Islam Fakultas Ilmu Tarbiyah dan Keguruan UIN Sunan Kalijaga Yogyakarta sebagai salah satu syarat untuk memperoleh gelar Sarjana Strata Satu Pendidikan.

Atas perhatiannya kami ucapkan terimakasih.

Wassalamu'alaikum, Wr. Wb.

Yogyakarta, 21 November 2017

Konsultan,

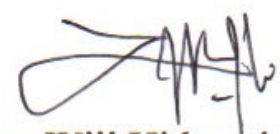

Dra. Wiji Hidayati, M.Ag

NIP. 196505231991032010 


\section{Universitas Islam Negeri Sunan Kalijaga}

FM-UINSK-BM-05-03/R0

\section{PENGESAHAN SKRIPSI/TUGAS AKHIR}

Nomor: B.63/UN.02/DT/PP.009/11/2017

Skripsi/Tugas Akhir dengan judul:

\section{Manajemen Pendidikan dalam Mengasuh Santri Gangguan Jiwa di Pondok} Pesantren Al Qodir Cangkringan Sleman Yogyakarta

Yang dipersiapkan dan disusun oleh:

$\begin{array}{ll}\text { Nama } & : \text { Arif Musafa } \\ \text { NIM } & : 13490032\end{array}$

Telah di Munaqasyahkan pada: Jum'at, 3 November 2017

Nilai Munaqasyah : A/B

dan dinyatakan telah diterima oleh Fakultas Ilmu Tarbiyah dan Keguruan UIN Sunan Kalijaga Yogyakarta.

TIM MUNAQASYAH:

Ketua Sidang

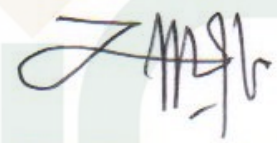

Dra. Wiji Hidayati,M.Ag

NIP. 196505231991032010

Penguji I

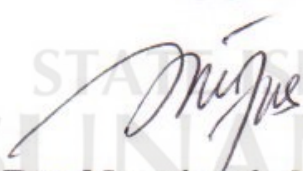

Dra. Nurrohmah, M.Ag

NIP. 195508231983032002

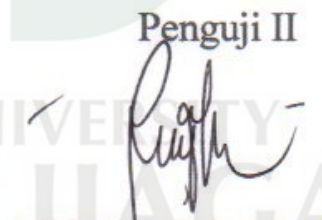

Miftahus Sa'adah, M.Ed

NIP. 198210192015032002

Yogyakarta, 20 November 2017

Dekan Fakultas Ilmu Tarbiyah Dan Keguruan

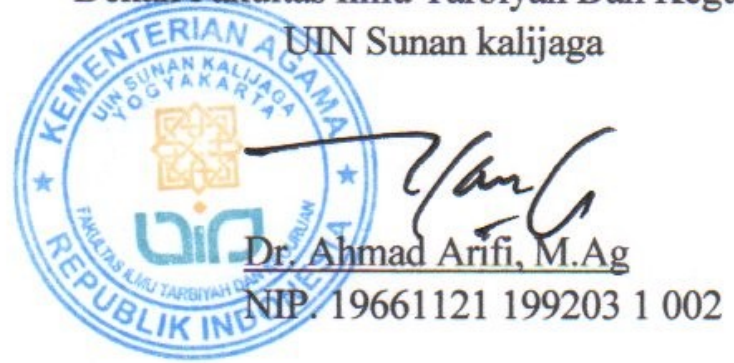




\section{MOTTO}

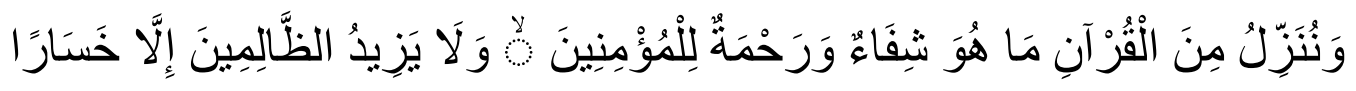

“Dan Kami Turunkan dari Al-Qur'an (sesuatu) yang menjadi penawar dan rahmat bagi orang yang beriman, sedangkan bagi orang yang zalim (Al-Qur'an itu) hanya akan menambah kerugian. Al-Isra' Ayat $82^{1}$

1 Departemen Agama RI, Al Qur'an dan Terjemahnya, (Bandung: CV Penerbit Diponegoro, 2007), hal. 290 


\section{PERSEMBAHAN}

Kupersembahkan Karya ini Kepada:

Almamaterku Manajemen Pendidikan

Islam Fakultas Ilmu Tarbiyah dan

Keguruan Universitas Islam Negeri

Sunan Kalijaga 


\title{
KATA PENGANTAR
}

\author{
بِسنمِ اللهِ الرَّحْنَ الرَّحِيْمِ

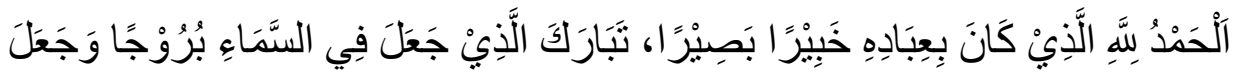

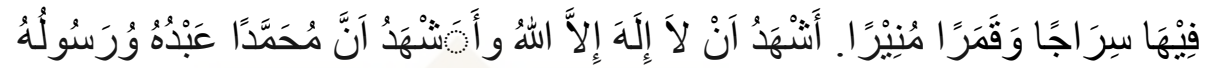

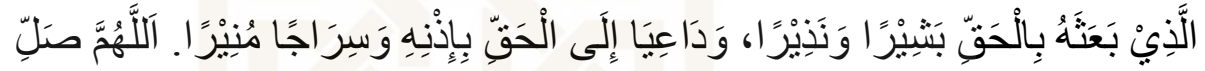

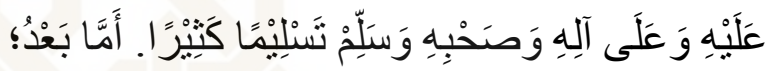

Puji Syukur peneliti panjatkan kehadirat Allah Swt yang telah memberikan rahmat, taufik, dan hidayah-Nya, sehingga peneliti dapat menyelesaikan penulisan skripsi ini. Peneliti menyadari bahwa dalam menyelesaikan skripsi ini benar-benar mendapatkan pertolongan dari Allah Swt. Shalawat serta salam semoga tetap tercurahkan kepada Nabi Muhammad saw sebagai suri tauladan bagi kita semua dan berharap mendapatkan syafaat-Nya di Yaumil Qiyamah amin. Amma ba'du.

Dalam penyusunan skripsi yang berjudul "Manajemen Pendidikan dalam Mengasuh Santri Gangguan Jiwa di Pondok Pesantren Al Qodir Cangkringan Sleman Yogyakarta". Penyusun menyadari bahwa banyak pihak yang telah membantu dari awal hingga akhir penyusunan skripsi ini, sehingga pada akhirnya skripsi ini dapat terselesaikan.

Oleh karena itu, dalam kesempatan ini penyusun ingin menyampaikan rasa terimakasih yang mendalam kepada:

1. Dr. Ahmad Arifi, M.Ag, selaku Dekan Fakultas Ilmu Tarbiyah dan Keguruan Universitas Islam Negeri Sunan Kalijaga Yogyakarta beserta jajarannya yang telah memberikan pengarahan yang berguna selama saya menjadi mahasiswa.

2. Dr. Imam Machali, M.Pd, selaku Ketua Jurusan Manajemen 
Pendidikan Islam yang telah banyak memberi motivasi selama saya menempuh studi selama ini.

3. Drs. H. Mangun Budiyanto, M.S.I, selaku dosen pembimbing akademik, terimakasih atas bimbingan dan dukungan selama peneliti menjadi mahasiswa Manajemen Pendidikan Islam.

4. Dra. Wiji Hidayati, M.Ag, selaku dosen pembimbing skripsi terimakasih atas bimbingan dan arahannya selama proses penelitian skripsi ini.

5. Segenap Dosen Program Studi Manajemen Pendidikan Islam yang telah memberikan bekal ilmu pengetahuan kepada peneliti, semoga apa yang telah diberikan dapat bermanfaat bagi seluruh mahasiswa dan masyarakat sekitar.

6. Bapak dan Ibu tercinta yang telah merawat, mendidik, membesarkan dan senatiasa memberikan dorongan serta dukungan dalam menempuhjenjang pendidikan di Universitas Islam Negeri Sunan Kalijaga Yogyakarta.

7. Sahabat - sahabat Mahasiswa/i Manajemen Pendidikan Islam 2013 (Cakrawala) yang tidak dapat disebutkan satu persatu, atas kerjasama dalam berproses bersama yang menjadi pengalaman berharga bagi peneliti.

Peneliti berharap mudah-mudahan semua bantuan, bimbingan, dukungan dapat diterima sebagai amal baik oleh Allah Swt, amin.

Yogyakarta, 7 Oktober 2017

Penulis

Arif Musafa

NIM: 13490032 


\section{DAFTAR ISI}

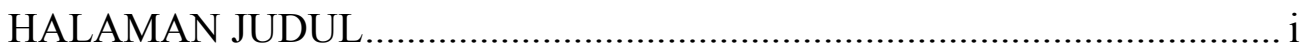

HALAMAN PERNYATAAN KESLIAN ................................................... ii

HALAMAN PERSETUJUAN SKRIPSI .................................................. iii

HALAMAN PERSETUJUAN PERBAIKAN SKRIPSI ............................... iv

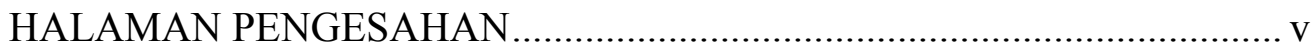

HALAMAN PERSEMBAHAN …...................................................... vi

HALAMAN MOTTO ….................................................................. vii

KATA PENGANTAR ….................................................................... viii

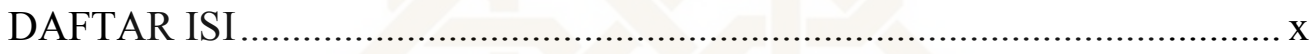

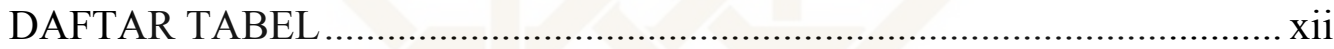

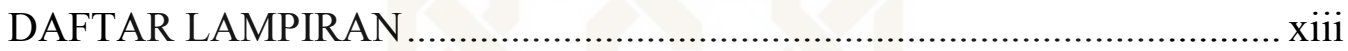

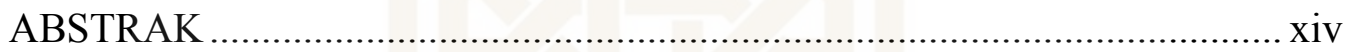

BAB I. PENDAHULUAN

A. Latar Belakang Masalah............................................................... 1

B. Rumusan Masalah .............................................................................. 6

C. Tujuan dan Kegunaan Penelitian ..................................................... 6

D. Kajian Penelitian Terdahulu........................................................... 7

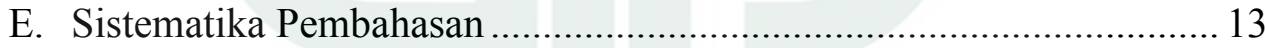

BAB II. LANDASAN TEORI DAN METODE PENELTIAN

A. Kajian Teori

1. Manajemen Pendidikan ......................................................... 15

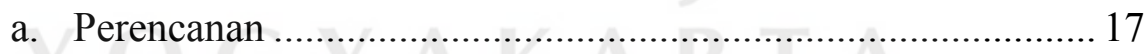

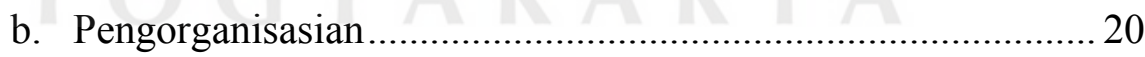

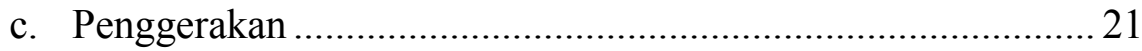

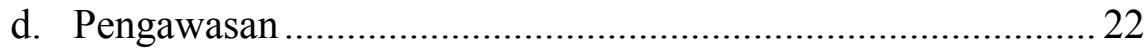

2. Pengasuhan Santri Gangguan Jiwa ............................................. 23

B. Metode Penelitian

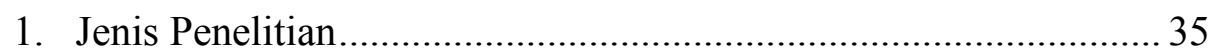

2. Teknik Penentuan Subjek (Populasi Dan Sample) ........................ 36 


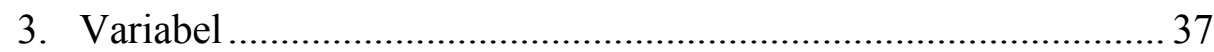

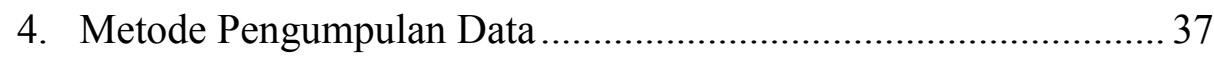

5. Teknik Analisis Data...................................................................... 40

6. Teknik Keabsahan Data .................................................................. 41

BAB III. GAMBARAN UMUM PONDOK PESANTREN AL-QODIR

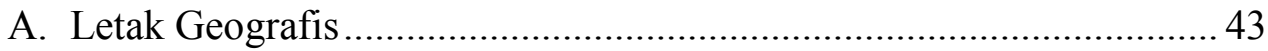

B. Sejarah Perkembangan Pondok Pesantren Al Qodir.............................. 44

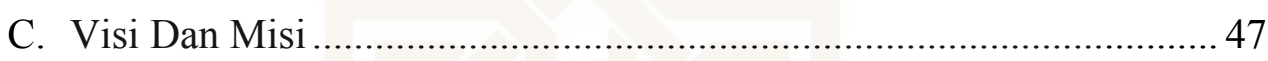

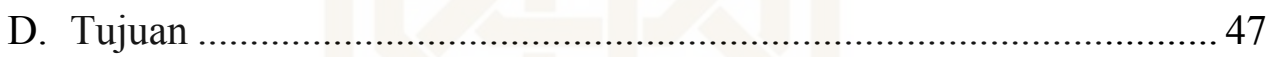

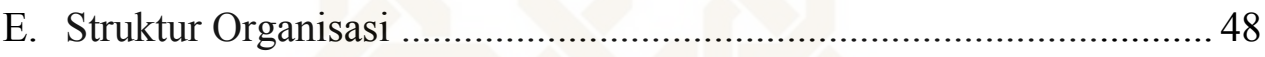

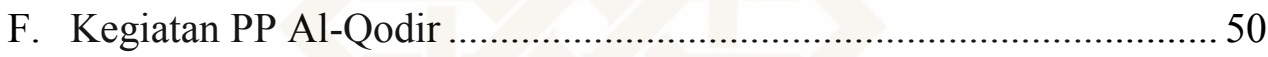

G. Program Pendidikan ......................................................................... 52

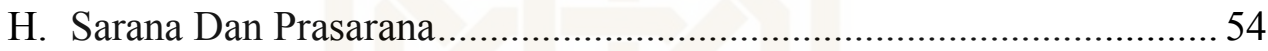

I. Data Pengajar, Pengurus dan Santri PP Al-Qodir............................... 57

BAB IV. MANAJEMEN PENDIDIKAN DALAM MENGASUH SANTRI GANGGUAN JIWA DI PONDOK PESANTREN AL-QODIR CANGKRINGAN SLEMAN YOGYAKARTA

A. Manajemen Pendidikan dalam Mengasuh Santri Gangguan Jiwa ........ 62

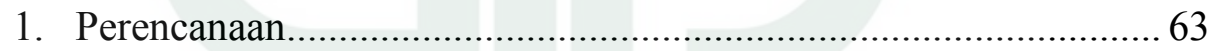

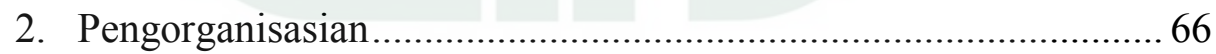

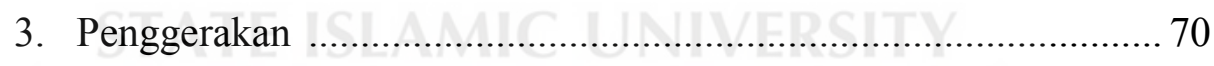

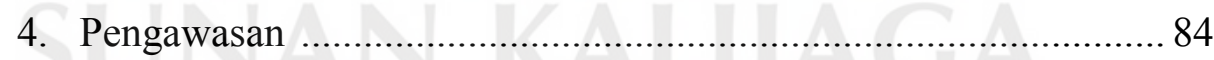

B. Hasil Dari Manajemen Pendidikan Santri Gangguan Jiwa ................... 89 BAB V. PENUTUP

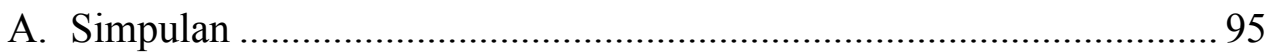

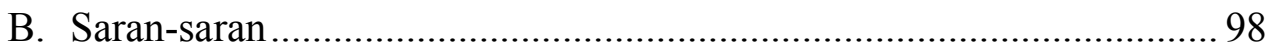

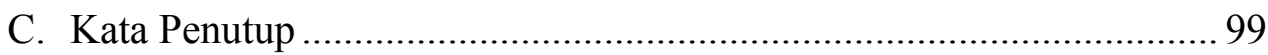

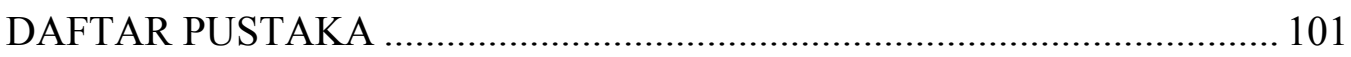

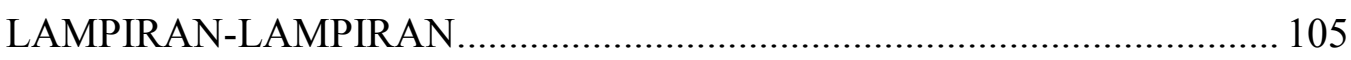




\section{DAFTAR TABEL}

Tabel 1: Daftar Jadwal madrasah diniyah PP Al Qodir .........................53

Tabel 2: Daftar Sarana dan prasarana Fisik PP Al Qodir........................55

Tabel 3: Daftar Data pengajar PP Al Qodir .........................................57

Tabel 4: Daftar Data santri PP Al Qodir ..............................................59 


\section{DAFTAR LAMPIRAN}

\begin{tabular}{|c|c|}
\hline Lampiran I & : Surat Penunjukan Pembimbing \\
\hline Lampiran II & : Bukti Seminar Proposal \\
\hline Lampiran III & : Berita Acara Seminar \\
\hline Lampiran IV & : Surat Izin Penelitian \\
\hline Lampiran V & : Pedoman Wawancara, Observai dan Dokumentasi \\
\hline Lampiran VI & : Hasil Wawancara \\
\hline Lampiran VII & : Catatan Lapangan \\
\hline Lampiran VIII & : Kartu Bimbingan Skripsi \\
\hline Lampiran IX & : Surat Keterangan Bebas Nilai C- \\
\hline Lampiran X & : Sertifikat PLP II \\
\hline Lampiran XI & : Sertifikat KKN \\
\hline Lampiran XII & : Sertifikat ICT \\
\hline Lampiran XIII & : Sertifikat IKLA \\
\hline Lampiran XIV & : Sertifikat TOEC \\
\hline Lampiran XV & : Sertifikat PKTQ \\
\hline Lampiran XVI & : Sertifikat SOSPEM \\
\hline Lampiran XVII & : Sertifikat OPAK \\
\hline Lampiran XVIII & : Foto Lokasi \& Kegiatan Santri Pesantren Al Qodir \\
\hline Lampiran XIX & : Data Santri Gangguan Jiwa dan Santri Pecandu Narkoba \\
\hline Lampiran XX & : Curriculum Vitae \\
\hline
\end{tabular}




\begin{abstract}
ABSTRAK
Arif Musafa, Manejemen Pendidikan dalam Mengasuh Santri Gangguan Jiwa di Pondok Pesantren Al Qodir Cangkringan Sleman Yogyakarta. Skripsi. Yogyakarta: Fakultas Ilmu Tarbiyah Dan Keguruan Universitas Islam Negeri Sunan Kalijaga Yogyakarta, 2017.

Latar belakang penelitian ini berawal dari ketertarikan peneliti dalam manajemen pendidikan pesantren Al Qodir khususnya bagi santri gangguan jiwa. Penelitian ini bertujuan untuk menganalisis manajemen pendidikan yang meliputi perencanaan, pengorganisasian, penggerakan dan pengawasan pesantren Al Qodir dalam pengasuhan santri gangguan jiwa.

Penelitian ini merupakan penelitian kualitatif dengan mengambil latar di pondok pesantren Al Qodir Cangkringan Sleman Yogyakarta. Teknik pengumpulan data dilakukan dengan cara observasi, wawancara mendalam dan dokumentasi. Teknik analisis data dengan cara mereduksi data, data display, dan menarik kesimpulan. Pemeriksaan keabsahan data dengan cara triangulasi sumber dan teknik serta dikombinaksikan dengan teori.

Hasil penilitian menunjukan: (1) manajemen pendidikan santri gangguan jiwa adalah: (a) perencanaan pondok pesantren Al Qodir yaitu meliputi perencanan harian, perencanan mingguan, perencanaan bulanan dan perencanan tahunan . (b) pengorganisasian pesantren Al-Qodir yaitu berdasarkan pada struktur organisasi yang berhubungan dengan perencaan diatas, (c) penggerakan meliputi pelaksanaan perencanaan yang dikordinir sesuai dengan tugas pokok dan fungsi (tupoksi) masing-masing, (d) pengawasan yang dilaksanakan yaitu sesuai dengan tugasnya masing-masing, baik dalam kegiatan belajar mengajar, kegiatan religius, kegiatan yang berhubungan dengan alam maupun terapi yang semuanya diawasi sesuai dengan tugasnya masing-masing. (2) hasil manajemen pendidikan dalam mengasuh santri gangguan jiwa yaitu dengan mengukur persentase kegiatan yang ada di pesantren yaitu 30\% dari kegiatan pesantren sedangkan $70 \%$ berasal dari diri santri dan keluarga. Sedangkan hasil dari kegiatan pesantren dan peran keluarga serta santri maka penyembuhan total $100 \%$. Hasil santri yang sudah sembuh yaitu 16 santri dari 20 santri gangguan jiwa dan santri pecandu narkoba atau $80 \%$ santri sudah sembuh sedangkan 4 santri masih dalam proses penyembuhan. Santri yang sudah mukim ada 6 orang dan 10 santri yang sudah sembuh masih di pesantren untuk mendalami ilmu agama.
\end{abstract}

Kata kunci: manajemen pendidikan, pengasuhan, gangguan jiwa, narkoba. 


\section{BAB I}

\section{PENDAHULUAN}

A. Latar Belakang Masalah

Kesehatan jasmani dan rohani merupakan kenikmatan dari Allah yang patut kita syukuri. Karena dengan sehat jasmani dan rohani seseorang dapat melaksanakan aktivitas tanpa ada halangan. Seseorang dapat berinteraksi dengan orang lain, dapat bertukar pikiran serta dapat berkomunikasi tanpa ada yang menghalangi. Banyak orang tidak mensyukuri kesehatan yang dimiliki. Mereka tidak sadar bahwa kesehatan merupakan salah satu kenikmatan terbesar yang harus kita syukuri dan kita jaga. Allah menciptakan makhluknya dengan sempurna. Namun kesempurnaan ini Allah cabut sesuai dengan kehendak-Nya. Banyak orang yang lahir sehat jasmani dan rohani, namun dalam perjalannya, mereka mendapatkan gangguan jiwa yang dapat merubah kebiasaan mereka menjadi kebiasaan yang kebalik dengan orang pada umumnya.

Dalam kehidupan sehari-hari kita sering menjumpai orang yang mengalami gangguan jiwa baik anak-anak, remaja, maupun orang dewasa. Gangguan jiwa yang banyak dijumpai merupakan PR bagi kita semua agar kita sebagai makhluk sosial peduli untuk membantu memulihkan kembali seperti semula/orang sehat jasmani dan rohani.

Gangguan jiwa ini merupakan ketidakmampuan seseorang menghadapi stres hidup yang dialami sehingga memunculkan perilaku- 
perilaku kelainan baik secara kognitif, afektif, maupun psikomotorik. Gangguan jiwa yang dialami oleh pasien sangat beragam tergantung dari latar belakang pasien terkena gangguan jiwa.

Gangguan jiwa sering kita jumpai seperti gangguan kepribadian, gangguan skizofrenia, gangguan bipolar dan gangguan lainnya. Menurut Eugen Bleuler dalam bukunya Jeffrey S. Nievid menjelaskan bahwa gangguan yang paling berat dari gangguan lainnya yaitu skizofrenia. Karakteristik utama skizofrenia berasal dari sindrom, yaitu terpisahnya fungsi otak yang mempengaruhi kognisi, respon-respon perasaan/afektif, dan tingkah laku². Gangguan jiwa ini dikarenakan stres dengan banyaknya beban yang harus diemban, maupun gelaja lain yang membuat seseorang menjadi stres (tidak kuat menahan beban yang dialami).

Gangguan jiwa berdampak langsung pada inidividu yang mengalaminya. Perilaku gangguan jiwa diantaranya suka berbicara sendiri, perkataannya tidak runtut, dan susah dipahami, sering terjadi penambahan kata-kata baru setiap terjadi interaksi. Penderita ini terganggu secara emosi, perilaku, maupun cara berinteraksi dengan lingkungan sekitar.

Sementara itu, menurut Rafei dalam skripsinya Indriani, Direktur World Health Organization (WHO) wilayah Asia Tenggara yang diungkap dalam Suara Pembaruan (2004), hampir satu per tiga dari penduduk di wilayah Asia Tenggara pernah mengalami gangguan neuropsikiatri. 104.

${ }^{2}$ Jeffrey S. Nevid dkk, Psikologi Abnormal, (Jakarta: Erlangga Edisi ke-5 jilid 2, 2003), hal. 
Menurut hasil survei Kesehatan Rumah Tangga (SKRT) 1995 di Indonesia diperkirakan 264 orang dari 1000 anggota rumah tangga menderita gangguan kesehatan jiwa. Menurut Azwar, Dirjen Bina Kesehatan Masyarakat Depkes, angka itu menunjukkan jumlah penderita gangguan kesehatan jiwa di masyarakat yang sangat tinggi, yakni satu dari empat penduduk Indonesia menderita gangguan jiwa mulai dari rasa cemas, depresi, stress, penyalahgunaan obat, kenakalan remaja sampai skizofrenia. ${ }^{3}$

Dalam menangani individu yang terkena gangguan jiwa, terdapat berbagai lembaga tempat rehabilitasi yang digunakan dalam mengobati individu yang terkena gangguan jiwa. Lembaga ini merupakan suatu wadah untuk menangani/mengasuh pasien yang mempunyai gangguan jiwa. Lembaga rehabilitasi yang dimaksud adalah rumah sakit jiwa, lembaga pemerintah non-kementerian (LPNK) yang berada dibawah presiden dan bertanggung jawab kepada presiden melalui menteri atau pejabat setingkat menteri, panti rehabilitasi, dan pondok pesantren.

Baru-baru ini pondok pesantren ikut andil dalam menangani santri/orang yang terkena ganguan jiwa. Banyak lembaga rehabilitasi yang kurang bisa menangani pasien gangguan jiwa membuat pesantren ikut dalam menangani pasien yang mengalami gangguan jiwa. Pondok pesantren yang menerima santri yang mempunyai gangguan jiwa agar ditangani

${ }^{3}$ Indriani Putri A, Gambaran Pola Asuh Penderita Skizofrenia. Skripsi, (Surakrta: fakultas Psikologi Universitas Muhammadiyah Surakarta, 2010) hal. 1. http://eprints.ums.ac.id/9279/. Diakses pada tanggal 25 Januari 2017. 
dengan metode khas dari pondok pesantren yang bersangkutan. Setiap pondok pesantren berbeda dalam menangani santri yang mempunyai gangguan jiwa seperti yang dilakukan oleh K.H Masrur Ahmad dalam mengasuh santri gangguan jiwa. K.H Masrur Ahmad dalam mengasuh tidak membeda-bedakan antara santri yang sehat dengan santri yang tidak sehat. Dalam menangani santri yang mempunyai gangguan jiwa, kyai menyamakan dengan santri biasa. Ada perlakuan khusus untuk santri yang susah ditangani/masih baru. Santri yang mempunyai kebutuhan khusus dibiarkan bebas untuk melakukan aktivitas yang ada di pondok pesantren tanpa mengisolasi dalam ruangan atau tempat terpencil, kecuali apabila ada suatu yang madzarat (mendesak). Dengan ini, santri yang bersangkutan tidak terbebani dengan tuntutan aturan yang memberatkan santri gangguan jiwa. $^{4}$

Dalam menangani santri yang mempunyai gangguan jiwa, Pondok pesantren maju dan berkembang apabila menerapkan manajemen dengan baik dan benar sesuai dengan kondisi yang relevan sesuai dengan kebutuhan masyarakat pada saat ini. Beberapa sistem manajemen yang baik menurut Masduki dalam skripsinya Ratna adalah adanya pola pikir yang teratur, pelaksanaan kegiatan yang teratur, dan penyikapan terhadap tugas-tugas kegiatan secara baik. Implikasi dari sistem manajemen ini meniscayakan

${ }^{4}$ Maesyaroh Nurohmah, Terapi Gangguan Jiwa: Proses "Terapi Humanis” Di Pondok Pesantren Al-Qodir Cangkringan Sleman-Yogyakarta. Skripsi, (Yogyakarta: Perpustakaan UIN Sunan Kalijaga 2015) hal. 5. 
lembaga pesantren menerapkan pola pengasuhan sedemikian rupa sehingga dapat mengoptimalkan proses pendidikan dan pembelajaran yang dilakukan untuk menyiapkan lulusan pesantren yang berkualitas dan komparatif. Pelaksanaan fungsi-fungsi tersebut secara umum dapat kita lihat pada komponen manajemen pesantren yang meliputi: kepemimpinan, pengambilan keputusan, kaderisasi, dan manajemen konflik. ${ }^{5}$ Banyak lembaga/instansi yang gagal dalam mencapai tujuan karena tidak menerapkan manajemen dengan baik, seperti perencanaan yang kurang matang, pengorganisasian yang kurang merata, sering miskomunikasi, tidak terstruktur dan lain sebagainya.

Dari uraian di atas terlihat bahwa dalam menangani santri yang mempunyai gangguan jiwa salah satunya diletakkan di lembaga rehabilitasi. Salah satu lembaga rehabilitasi adalah pondok pesantren. Pondok pesantren ini akan mudah menangani santri yang berbeda apabila menggunakan metode/cara yang berbeda dengan santri biasa.

Penulis mengambil penelitian ini di Pondok Pesantren Al-Qodir Cangkringan Sleman yang dipimpin langsung oleh K.H Masrur Ahmad. Tujuan berdirinya Pondok Pesantren Al-Qodir yaitu untuk sebagai tempat mentransfer ilmu-ilmu agama seperti kajian kitab kuning, Madrasah Diniyah, sorogan dan bandongan yang diikuti semua santri, kegiatan

\footnotetext{
${ }^{5}$ Ratna Hestiana, Manajemen Pengasuhan Santri Autis Di Pondok Pesantren Ainul Yakin Bantul D.I.Yogyakarta. Skripsi, Tidak Diterbitkan, (Yogayakarta: Perpustakaan UIN Sunan Kalijaga, 2016) hal. 7. http://digilib.uin-suka.ac.id/23209/. Diakses pada tanggal 20 Januari 2017.
} 
mujahadah yang dilaksanakan setiap hari Jum'at serta membantu memulihkan santri gangguan jiwa dan santri pecandu narkoba. Banyaknya santri yang mempunyai gangguan jiwa membuat penulis tertarik dalam penelitian tersebut. Pondok pesantren ini bertempat di Cangkringan, Sleman, D.I. Yogyakarta.

B. Rumusan Masalah

Berdasarkan latar belakang yang telah diuraikan di atas, maka peneliti merumuskan masalah sebagai berikut:

1. Bagaimana manajemen pendidikan dalam mengasuh santri gangguan jiwa di pondok pesantren Al Qodir Cangkringan Sleman?

2. Bagaimana hasil dari manajemen pendidikan pesantren dalam mengasuh santri ganguan jiwa di pondok pesantren Al-Qodir Cangkringan Sleman?

C. Tujuan dan Kegunaan Penelitian

1. Tujuan Penelitian

Dalam penelitian skripsi ini, tujuan yang akan dicapai adalah sebagi berikut:

a. Mengetahui manajemen pendidikan dalam mengasuh santri gangguan jiwa di pondok pesantren Al Qodir Cangkringan Sleman.

b. Mengetahui hasil dari manajemen pendidikan pesantren dalam pengasuhan santri gangguan jiwa di pondok pesantren Al-Qodir Cangkringan Sleman. 
2. Kegunaan Penelitian

a. Manfaat teoritis

1) Penelitian ini diharapkan dapat bermanfaat untuk menangani kasus anak yang mempunyai gangguan jiwa.

2) Hasil penelitian ini semoga bermanfaat bagi para pengasuh baik di pondok pesantren lain maupun di tempat rehabilitasi lainnya yang menerapkan metode pendidikan yang sangat baik oleh kiyai Masrur Ahmad dan pengasuh pembantunya.

b. Manfaat praktis

Hasil penelitian ini semoga bermanfaat bagi Pondok Pesantren Al-Qodir Cangkringan Sleman untuk lebih baik lagi manajemen penanganan santri gangguan jiwa baik dari pola asuh, pendidikan khususnya maupun yang lain.

D. Kajian Penelitian Terdahulu

Kajian penelitian terdahulu mempunyai tujuan yaitu melihat tematema yang sama dengan judul skripsi yang akan diteliti. Di antara tema yang sama antara lain:

“Manajemen Pengasuhan Santri Autis di Pondok Pesantren Ainul Yakin Bantul D.I.Yogyakarta" yang disusun oleh Ratna Hestiana Jurusan Manajemen Pendidikan Islam Fakultas Ilmu Tarbiayah dan Keguruan UIN 
Sunan Kalijaga Yogyakarta. ${ }^{6}$ Penelitian membahas tentang manajemen pengasuhan santri autis/gangguan jiwa sejak lahir. Penelitian ini membahas mengenai penanganan santri yang mengalami gangguan jiwa khususnya Autis. Dalam skripsinya dijelaskan bahwa pondok pesantren yang diteliti ini menggunakan manajemen pengasuhan khusus pada santri yang mengalami gangguan jiwa. Ratna Hestiana menjelaskan bahwa dalam penelitiannya pondok pesantren ini menggunakan fungsi manajemen (perencanaan, pengorganisasian, penggerakan dan pengawasan) dalam mengasuh santri autis. Pertama, perencanaan yang dilakukan adalah RPTS (Rencana Program Tretmen Santri) yaitu untuk mengasuh santri yang mempunyai kebiasaan yang berbeda-beda dan LPTS (Laporan Program Tretmen Santri) berfungsi sebagai bahan perkembangan santri yang mempunyai kebutuhan khsusus. Pengorganisasian sama seperti pondok pesantren pada umumnya, yaitu ada pengasuh, bendahara, ketua pondok, sekretaris dan lainnya namun sedikit perbedaan dalam mengatur jadwal khusus bagi santri autis. Sedangkan pelaksanaan dilakukan oleh pengasuh pondok, pembimbing dan guru. Pengawasan yang lakukan oleh pengasuh yaitu mengelilingi kelas dan asrama setiap hari, melihat proses pembelajaran, sedangkan untuk para santri diberikan tugas setiap hari untuk mengetahui proses perkembangan. Dan yang terakhir adalah dengan tes

${ }^{6}$ Ratna Hestiana, Manajemen Pengasuhan Santri Autis di Pondok Pesantren Ainul Yakin Bantul D.I.Yogyakarta. Skripsi, Tidak Diterbitkan, (Yogyakarta: Perpustakaan UIN, 2016). http://digilib.uin-suka.ac.id/23209/. Diakses pada tanggal 20 Januari 2017. 
akademik/tes tertulis yang dilakukan setiap semester untuk dilaporkan kepada wali santri untuk mengetahui perkembangan anaknya yang ada di pondok pesantren. Model pengasuhannya menggunakan model primitif yaitu proses bimbingan yang dilakukan oleh pengasuh, pembimbing, dan guru dalam rangka untuk memandirikan santri autis.

Perbedaan dengan penelitian ini adalah manjemen pendidikan di pesantren Al Qodir yang diterapkan yang lebih fokus pada penerapan pendidikan yang khusus diberikan pada santri gangguan jiwa dan santri pada umumnya. Kegiatan-kegiatan pembelajaran seperti ngaji sorogan dan setoran amalan (wirid) yang menjadi rutinitas menjadi objek penelitian penulis. Selain itu, pembelajaran yang berkenaan dengan alam juga termasuk dalam kegiatan pembelajaran santri ganguan jiwa.

Kedua, Terapi Gangguan Jiwa: Proses "Terapi Humanis" di Pondok Pesantren Al-Qodir Cangkringan Sleman-Yogyakarta" oleh Maesyaroh Nurohmah Jurusan Ilmu Kesejahteraan Sosial Fakultas Dakwah Kominukasi UIN Sunan Kalijaga Yogyakarta. ${ }^{7}$ Penelitian ini membahas tentang terapi humanis yang ditrapkan oleh Pondok Pesantren Al-Qorir Cangkringan Sleman dalam menangani santri gangguan jiwa. Adapun terapi yang dilakukan adalah tidak membedakan santri sehat dengan santri yang mengalami gangguan jiwa. Santri khusus ini diberi keleluasaan untuk

${ }^{7}$ Maesyaroh Nurohmah, Terapi Gangguan Jiwa: Proses "Terapi Humanis" di Pondok Pesantren Al-Qodir Cangkringan Sleman-Yogyakarta. Skripsi, Tidak Diterbitkan, (Yogyakarta: Perpustakaan UIN Sunan Kalijaga, 2015) 
menghirup udara segar dan keleluasaan dalam melakukan aktivitas yang ada di pondok pesantren.

Berbagai tahap dilakukan untuk menyembuhkan santri yang mempunyai gangguan jiwa sebagai berikut:

1. terapi rehabilitasi

2. terapi lingkungan

3. psikofarmokoterapi (terapi obat)

4. dan terapi somatic

Sedangkan hasil dari penyembuhan ini adalah santri dikembalikan ke keluarga masing-masing dan bekerja sesuai dengan keinginan santri.

Dari isi penelitian diatas lebih menekankan pada terapi humanis yang megedepankan penyembuhan pasien/santri sedangkan konsen penelitian ini lebih fokus pada manajemen pendidikannya yang menjadi objek penelitiannya. Penelitian ini lebih fokus pada manajemen pendidikan yang didalamnya dijabarkan perencanaan, pengorganisasian, penggerakan dan pengawasan dalam proses pendidikan yang ada di pesantren Al Qodir.

Ketiga, Skripsi yang berjudul "Implementasi Manajemen Pendidikan Di Pondok Pesantren Nurul Ummah Kotagede Yogyakarta" oleh Muhammad Asrori Jurusan Kependidikan Fakultas Tarbiyah dan Keguruan UIN Sunan Kalijaga Yogyakarta. ${ }^{8}$ Skripsi ini dibatasi dalam

${ }^{8}$ Muhammad Asrori, Implementasi Manajemen Pendidikan Di Pondok Pesantren Nurul Ummah Kotagede Yogyakarta. Skripsi, Tidak Diterbitkan, (Yogyakarta: perpustakaan UIN Sunan Kalijaga, 2009) 
penelitiannya fokus pada Manajemen Personalia dan Manajemen Pembiayaan. Dalam skripsinya dijelaskan bahwa dalam manajemen personalia sudah berjalan dengan baik dan sesuai dengan teori manajemen yaitu perencanaan, perekrutan pengurus, penempatan dan penugasan, cara memeliharanya, pembinaan dan evaluasi pengurus serta pemutusan hubungan kerja. Sedangkan Manajemen Pembiayaan sudah melakukan budgeting (penyusunan anggaran), accounting (pembukuan), dan auditing (pemeriksaan), anggaran rutin dan anggaran pembangunan dan dana penunjang pendidikan (DPP).

Perbedaan penelitian di atas dengan penelitian yang akan penulis lakukan dengan judul "Manajemen Pendidikan dalam Mengasuh Santri Gangguan Jiwa diPondok Pesantren Al-Qodir Cangkringan Sleman Yogyakarta" dengan skirpsi diatas penulis memfokuskan pada manajemen pendidikan dalam menuntaskan santri yang mempunyai gangguan jiwa dan lebih fokus pada perencanaan, pengorganisasian, penggerakan dan pengawasan kegiatan santri selama di pesantren.

Keempat, Skripsi yang berjudul "Manajemen Pondok Pesantren dalam Pengembangan Kepribadian Santri (Studi Kasus di Pondok Pesantren Al-Hikmah Sumberjo, Karangmojo, Gunung Kdiul, Yogyakarta)" oleh Supanta Jurusan Kependidikan Islam Fakultas Ilmu Tarbiyah dan 
Keguruan UIN Sunan Kalijaga Yogyakarta. ${ }^{9}$ Penelitian ini menjelaskan manajemen dari segi fungsi yaitu perencanaan, pengorganisasian, penggerakan, dan pengawasan serta membahas faktor-faktor penghambat dan pendukung dalam menerapkan manajemen pondok pesantren. Dalam skripsi diatas menjelaskan secara lengkap fungsi-fungsi manajemen yaitu: perencanan meliputi: what (apa), why (kenapa/mengapa), when (kapan), who (siapa), where (dimana), how (bagaimana). Fungsi kedua pengorganisasian ditandai dengan struktur organisasi. Fungsi ketiga penggerakan adalah pemimpin memberi suatu motivasi, bimbingan, musyawarah, menjalin hubungan dan komunikasi. Dan terakhir pengawasan dilakukan oleh pengasuh dan pengurus pondok dengan membuat tolak ukur yang dipakai untuk mencapai keberhasilan penerapan manajemen pondok tersebut.

Perbedaan penelitian diatas dengan penelitian yang akan penulis lakukan adalah peneliti lebih mendalam/mengerucut mengenai manajemen pendidikan yang menjadi fokus penelitian meliputi perencanaan, pengorganisasian, penggerakan dan pengawasan pesantren Al Qodir dalam mengasuh santri gangguan jiwa. Sedangkan kegiatan belajar mengajar, wirid, dan terapi merupakan kegiatan santri gangguan jiwa yang selalu diamalkan setiap hari.

\footnotetext{
${ }^{9}$ Supanta, Manajemen Pondok Pesantren dalam Pengembangan Kepribadian Santri (Studi Kasus di Pondok Pesantren Al-Hikmah Sumberjo, Karangmojo, Gunung Kdiul, Yogyakarta). Skripsi, Tidak Diterbitkan, (Yogyakarta: Perpustakaan UIN Sunan Kalijaga, 2011)
} 


\section{E. Sistematika Pembahasan}

Sistematika ini menjelaskan mengenai gambaran secara sistematis skripsi yang akan dibagi bab per bab, untuk memberikan gambaran yang jelas mengenai penelitian ini, maka peneliti membagi menjadi lima BAB sebagai berikut:

Bab Pertama adalah pendahuluan menjelaskan uraian permasalahan yang hendak diteliti. Pendahuluan ini berisi subbab yang ada di dalamnya yaitu latar belakang menjelaskan masalah yang sedang dialami pada saat ini, rumusan masalah berisi pertanyaan yang menjadi acuan dalam menjawab isi dari penelitian tersebut, tujuan penelitian yaitu berisi capaian-capaian yang ingin dicapai, dan sistematika pembahasan yaitu pembagian bab per bab agar mudah dipahami dan lebih sistematis.

Bab Kedua berisi Kajian Teori dan Metode Penelitian. Kajian Teori yang berisi tentang teori yang relevan sesuai dengan penjabaran dari judul penelitian. Metode Penelitian berisi tentang cara mengmbil data, pendekatan penelitian, sumber data penelitian, teknik pengumpulan data dan teknik analisis data.

Bab Ketiga berisi tentang Gambaran Umum yang berkaitan dengan Judul/Tema, dalam bab ini menjelaskan tentang obyek yang diteliti dan mencakup isi dari hasil peneltiain lapangan, yaitu tentang gambaran umum pondok pesantren Al-Qodir Cangkringan Sleman yakni. (a) Letak Geografis, (b) Sejarah Berdirinya, (c) Visi dan Misi (d) Tujuan (e) struktur Organisasi, (f) Kegiatan Pondok Pesantren Al Qodir (g) Program 
Pendidikan (h) Sarana dan Prasarana, (i) Data Pengajar, Pengurus dan Santri Pondok Pesantren Al Qodir.

Bab Keempat berisi tentang hasil lapangan yang sudah diteliti, hasil olah data dan analisis data tentang Manajemen Pendidikan dalam Mengasuh Santri Gangguan Jiwa di Pondok Pesantren Al-Qodir Cangkringan Sleman Yogyakarta, Tentang bagaimana manajemen penanganan santri gangguan jiwa dari segi pendidikan baik pendidikan keagamaan, rutinitas maupun terapi untuk menyembuhkan santri yang mempunyai gangguan khusus dan pola pengasuhan santri yang sama dengan santri biasa baik dari mengaji rutinitas maupun hal lain yang dilakukan santri lain.

Bab Kelima berisi tentang Kesimpulan dari hasil penelitian, saransaran peneliti terhadap pihak atau peneliti lain dari penulis dan kata penutup berupa ucapan syukur. 


\section{BAB V}

\section{PENUTUP}

\section{A. Simpulan}

Setelah penulis mengadakan penelitian serta menganalisis hasil penelitian terhadap manajemen pendidikan dalam mengasuh santri gangguan jiwa di pondok pesantren Al Qodir, maka penulis menyampaikan beberapa kesimpulan sebagai berikut:

1. Manajemen pendidikan santri gangguan jiwa dilaksanakan dengan menjalankan fungsi manajemen yaitu perencanaan, pengorganisasian, penggerakan dan pengawasan yang didalamnya berisi tentang terapi santri, kegiatan religius serta kegiatan yang berhubungan dengan alam. Sedangkan program kegiatan yang ada di pesantren, santri gangguan jiwa tetap wajib menjalankan didampingi oleh dua pengurus untuk menjalankan aktivitas serta mengontrol perkembangan santri tersebut. Manajemen pendidikan pesantren Al Qodir dalam mengasuh santri yang ada di pesantren Al Qodir yaitu mengunakan prinsip memanusiakan manusia.

a. Perencanaan

Perencanaan yang ada di pesantren Al Qodir belum berjalan dengan baik, melainkan melaksanakan rutinitas kegiatan setiap tahun baik rutinitas harian yaitu sholat jamaah, kegiatan belajar mengajar, serta kegiatan yang berhubungan dengan alam, kegitan muhajadah yang dilaksanakan setiap hari jum'at, pengajian umum 
dilaksanakan setiap bulan dan ditutup dengan akhirussanah. Sedangkan Madrasah Diniyah sudah melaksanakan perencanaan yang dilakukan tahunnya namun masih dalam tahap berkembang.

b. Pengorganisasian

Pengorganisasian manajemen pengasuhan santri gangguan jiwa di pondok pesantren Al Qodir yaitu apa pimpinan pesantren/pengasuh pesantren, lurah pondok/ketua, sekretaris, bendahara, dan manajer tingkat bawah yang membantu melancarkan kegiatan yang ada di pesantren khususnya dalam penanganan santri gangguan jiwa. Sedangkan untuk pembagian kerjanya yaitu setiap santri gangguan jiwa didampingi oleh dua pengurus.

c. Penggerakan

Penggerakan atau pelaksanaan yang dilakukan oleh pimpinan, pengasuh, pengurus dan pengajar pesantren Al Qodir untuk membantu santri khususnya santri gangguan jiwa dan santri pecandu narkoba yang mendapatkan kebutuhan khusus. Pelaksanaan harus dilakukan oleh setiap lembaga dan organisasi karena dengan adanya pengkoordinasian maka setiap kegiatan yang dilaksanakan dapat berjalan dengan baik. Dengan adanya perencanaan yang sudah baik dan pengkoordinasian yang terstruktur maka semua elemen yang ada di pesantren Al Qodir khususnya dengan mudah melaksanakan kegiatan yang sudah direncanakan. Oleh karena itu, peraturan yang dibuat harus ditaati dan dilaksanakan oleh pengasuh, pengurus 
maupun santri sehingga setiap elemen yang ada di pesantren menghormati aturan yang ada.

d. Pengawasan

Pengawasan yang dilakukan yaitu mengawasi kegiatan santri gangguan jiwa dengan melihat jadwal kegiatan sehari-hari baik ngaji, makan, mandi, sholat, wiirid dan kegiatan. Sedangkan pimpinan pondok mengontrol santri gangguan jiwa saat sholat jamaah dan saat mengaji dengan beliau. KH. Masrur Ahmad selaku pimpinan pesantren selalu mengamati perkembangan santri gangguan jiwa baik dari cara duduknya, cara bicara dan tingkah laku yang masih mencirikan orang gangguan jiwa atau sudah menjadi orang yang sehat.

2. Hasil dari manajemen dalam mengasuh santri gangguan jiwa

Santri gangguan jiwa yang diterapi menggunakan prinsip memanusiakan manusia dapat berjalan sesuai dengan waktu yang ditentukan bahkan lebih cepat dari yang direncanakan. Sebagai contoh santri pecandu narkoba bisa sembuh total dalam jangka waktu tiga bulan dan proses menghilangkan paranoid/halusinasi yaitu sampai 2 tahun. Adapaun yang menjadi kendala yaitu karakter santri tersebut yang manja sehingga menjadi sulit bagi pengurus dan pengasuh untuk menerapkan model terapi dan susah dalam mengaturnya. Jalan lain yang bisa dilakukan adalah membutuhkan peran orang tua sebagai faktor pendukung sekaligus menyalurkan ikatan emosional antara orang tua 
dengan anak. Maka dari itu, setiap tiga bulan sekali santri gangguan jiwa dan pecandu narkoba dipulangkan ke keluarga untuk mendapatkan perhatian dari orang tua.

Sedangkan persentase keberhasilan dalam penyembuhan santri gangguan jiwa yaitu $30 \%$ berasal dari kegiatan yang ada di pesantren 70 $\%$ berasal dari santri gangguan jiwa dan orang tua. Maka dari itu, pesantren sagat membutuhkan peran keluarga dalam menyembuhkan santri gangguan jiwa dan narkoba. Santri yang mendapatkan kebutuhan khusus ini sudah sembuh 16 santri diantaranya 6 santri sudah kembali ke keluarga sedangkan 10 santri yang sudah sembuh masih di pesantren Al Qodir untuk mendalami ilmu agama. Hingga saat ini santri yang sudah sembuh yaitu $80 \%$ atau 16 dari 20 santri yang mendapatkan proses penyembuhan. Sedangkan santri gangguan jiwa dan narkoba rata-rata masuk ke pesantren Al Qodir 2013-2015 dan pada tahun ini ditambah satu santri gangguan jiwa yang baru. Saat ini santri yang masih mendapatkan proses terapi di pesantren Al Qodir yaitu 4 santri.

B. Saran-saran

Saran-saran yang penulis sampaikan dalam skripsi ini ditujukan pada pondok pesantren Al Qodir dalam mengasuh santri gangguan jiwa yang ada di pesantren Al Qodir.

1. Pengasuh dan pengurus santri gangguan jiwa

Pengasuh dan pengurus santri gangguan jiwa tetap semangat dan sabar dalam mengasuh santri gangguan jiwa tertama menghadapi santri 
yang mempunyai karakter manja. Semoga dengan berjalannya waktu dan pergantian pengurus pada tahun ini, pesantren Al Qodir dapat memanaj lagi kegiatan yang diminati santri gangguan jiwa dan serta peraturan dari awal sampai akhir penyembuhan sudah dijelaskan kepada santri terutama pada orang tua santri tersebut apa saja kebutuhan yang menyangkut keberhasilan anaknya dapat dipenuhi.

2. Santri

Banyak santri gangguan jiwa yang ada di pesantren Al Qodir, berharap santri yang khusus menimba ilmu agama dan ilmu umum bisa mengambil pelajaran/ibroh mengenai gangguan-gangguan yang menimpa santri gangguan jiwa dan bisa menjauhi narkoba karena banyak santri yang dapat ke pesantren Al Qodir sebagai pecandu narkoba. Sedangkan bagi santri gangguan jiwa dan pecandu narkoba berharap setelah sembuh dapat berktifitas seperti orang pada umumnya dan menjalin kehidupan kedepan yang lebih baik lagi.

C. Kata penutup

Alhamdulillah segala puji bagi Allah tuhan semesta Alam yang telah melimpahkan rahmat, kekuatan serta kemudahan kepada diri penulis dalam menyelesaikan skripsi yang berjudul: Manajemen Pendidikan dalam Mengasuh Santri Gangguan Jiwa di Pondok Pesantren Al Qodir Cangkringan Sleman Yogyakarta.

Sholawat serta salam tetap tercurahkan kepada Nabi Muhammad SAW yang selalu menjadi suri tauladan bagi kita semua yang selalu kita tiru 
perbuatannya dalam kehidupan sehari-hari dan menuntun kita dari zaman penuh kegelapan menuju jalan yang terang yakni agama islam.

Dengan kesadaran yang tinggi, penilis sangat jauh dari kemampuan yang ada dan kesempurnaan dalam menyelesaikan skripsi ini. Penulis mengharap kritik dan saran yang membangun agar bisa memperbaiki kesalahan atau kekeliruan dalam menyelesaikan skripsi ini. Semoga skripsi ini berguna khususnya bagi penulis dan umumnya bagi pembaca sekalian serta dunia pondok pesantren yang didalamnya mengasuh santri gangguan jiwa dan pecandu narkoba. Dan selanjutnya penulis ucapkan terimakasih kepada semua pihak yang telah membantu penulis dalam mengerjakan skripsi ini hingga selesai. 


\section{DAFTAR PUSTAKA}

Arikunto, Suharsimi dan Yuliani, Lia, Manajemen Pendidikan, Yogyakarta: Aditya Media bekerjasama dengan Fakultas Ilmu Pendidikan UNY, 2008.

Asrori, Muhammad, "Implementasi Manajemen Pendidikan Di Pondok Pesantren Nurul Ummah Kotagede Yogyakarta”. Skripsi, Tidak Diterbitkan, Yogyakarta: perpustakaan UIN Sunan Kalijaga, 2009.

Bakran, Hamdan, Konseling dan Psikoterapi Islam, Yogyakarta: Fajar Pustaka Baru, 2004.

Burhanuddin, analisis administrasi manajemen dan kepemimpinan pendidikan, Jakarta, Bumi Aksara: 1994.

Daradjat, Zakiyah, kesehatan mental, Jakarta: Gunung Agung 1978.

Davison, Gelard C dkk, Psikologi Abnormal, Jakarta: PT Raja Garafindo Persada, 2012.

Departemen Agama RI, Al Qur'an dan terjemahnya, Bandung: CV Penerbit Diponegoro, 2007.

Departemen Agama RI, Pondok Pesantren dan Madrasah Diniyah pertumbuhan dan perkembangannya, Jakarta, Direktorat Jendral Kelembagaan Agama Islam: 2003.

Hanafi, Mamduh M., Manajemen, Yogyakarta: Unit Penerbit dan Percetakan Akademi Manajemen Perusahaan YKPN, 2003.

Haryanto, Sugeng, Persepsi Santri Terhadap Perilaku Kepemimpinan Kyai di Pondok Pesantren (Studi Interaksionalisme Simbolik di Pondok Pesantren Sidogiri-Pasuruan), Jakarta: Kementerian Agama RI, 2012. 
Hestiana, Ratna, "Manajemen Pengasuhan Santri Autis Di Pondok Pesantren Ainul Yakin Bantul D.I.Yogyakarta”. Skripsi, Tidak Diterbitkan, Yogayakarta: Perpustakaan UIN Sunan Kalijaga, 2016

Kementerian Agama RI, Al-Qur'anulkarim Terjemah Tafsir perkata, Bandung: CV Insan Kamil, 2011.

Kurniadin, Didin dan Machali, Imam, Manajamen Pendidikan Konsep \& Prinsip Pengelolaan Pendidikan, Yogyakarta: Ar-Ruzz Media, 2012.

Kusumawati, Farida dkk. Buku Ajar Keperawatan Jiwa, Jakarta: Salemba Medika, 2011.

Majid, Nur Cholis, Bilik-bilik Pesantren, Jakarta: Paramadina, 1997.

Masyhud, M. Sulthon dan Khusnurdilo, Moh., Manajemen Pondok Pesantren, Jakarta: Diva Pustaka, 2005.

Mulyono, Manajemen Administrasi \& Organisasi Pendidikan, Yogyakarta: ArRuzz Media, 2008.

Nasir, Abdul dkk, Dasar-dasar Keperawatan Jiwa, Jakarta: Salemba Merdeka, 2011.

Nasori, Fuad, Rumusan Hasil Seminar Spsikoterapi Islam Psikologi Umum Malang, Yogyakarta: Pustaka Pelajar, 1997.

Nevid, Jeffrey S. dkk. Psikologi Abnormal, Jakarta: Erlangga Edisi ke-5 jilid 2, 2003. 
Nurohmah, Maesyaroh, Terapi Gangguan Jiwa: Proses "Terapi Humanis" Di Pondok Pesantren Al-Qodir Cangkringan Sleman-Yogyakarta. Skripsi, Yogyakarta: Perpustakaan UIN Sunan Kalijaga 2015.

Putri A, Indriani, Gambaran Pola Asuh Penderita Skizofrenia. Skripsi, (Surakrta: fakultas Psikologi Universitas Muhammadiyah Surakarta, 2010) hal. 1. http://eprints.ums.ac.id/9279/. Diakses pada tanggal 25 Januari 2017.

Ratna, Nyoman Kutha, Metodologi Penelitian kajian budaya dan Ilmu Sosial Humaniora pada Umumnya, Yogyakarta: Pustaka Pelajar cet. Ke-1, 2010.

Staf Pengajar Departemen Farmokologi, Kumpulan Kuliah Farmokologi, Jakarta: Buku Kedokteran EGC, 2008.

Semiun, Yustiyunus, Kesehatan Mental 3, Yogyakarta: Kanisius, 2006.

Sukmadinata, Nana Saodih, Metode Penelitian Pendidikan, Bandung: PT Remaja Rosdakarya, 2011.

Sugiono, Metode Penelitian Pendidikan Pendekatan Kualitatif Kuantitatif dan $R \& D$, Bandung: Alfabeta, 2012.

Supanta, "Manajemen Pondok Pesantren dalam Pengembangan Kepribadian Santri (Studi Kasus di Pondok Pesantren Al-Hikmah Sumberjo, Karangmojo, Gunung Kdiul, Yogyakarta)". Skripsi, Tidak Diterbitkan, Yogyakarta: Perpustakaan UIN Sunan Kalijaga, 2011.

Supriana, Dadang dan Sylvana, Andi, Manajemen, Banten: Universitas Terbuka, 2014.

Susanti, Herni, "Defisit Keperawatan pada Klien Skizofrenia: Aplikasi Teori Keperawatan Orem". Jurnal Keperawatan Indonesia Vol.13, NO. 2 (Depok, Fakultas Keperawatan Universitas Indonesia: 2010), http://jki.ui.ac.id/index.php/jki/article/view/237. Diakses pada tanggal 26 Januari 2017.

Terry, Gerge R, Asas-asas Manajemen, Bandung: PT. Alumni, 2006. 
Terry, George R., Prinsip-prinsip Manajemen, Jakarta: Radar Jaya Offset, 1991.

TIM Revisi Kamus Umum Bahasa Indonesia edisi ke-3, Kamus Umum Bahasa Indonesia, Jakarta: Balai Pustaka, 2011. 
Nomor : : UIN.2/KJ.MPI/PP.00.9/291/2017

Lampiran : 1 (Satu) jilid proposal

Perihal : Penunjukan Pembimbing Skripsi

\section{Kepada Yth. :}

Dra. Wiji Hidayati, M. Ag

Dosen Jurusan MPI Fakultas Ilmu Tarbiyah dan Keguruan

UIN Sunan Kalijaga

Yogyakarta

Assalamu'alaikum $W r$. Wb.

Berdasarkan hasil rapat pimpinan Fakultas Ilmu Tarbiyah dan Keguruan UIN Sunan Kalijaga Yogyakarta pada tanggal 13 Januari 2017 perihal pengajuan Proposal Skripsi Mahasiswa Program Studi Manajemen Pendidikan Islam Tahun Akademik 2016/2017 setelah proposal tersebut dapat disetujui Fakultas, maka Bapak/lbu telah ditetapkan sebagai pembimbing Skripsi Saudara:
Nama
: ArifMusafa
NIM
: 13490032
Jurusan
: Manajemen Pendidikan Islam
Judul
: MANAJEMEN PENDIDIKAN PESANTREN AL-QODIR CANGKRINGAN SLEMAN DALAM MENANGANI SANTRI SCIZHPRENIA

Demikian agar menjadi maklum dan dapat dilaksanakan sebaik-baiknya.

Wassalamu'alaikum Wr.Wb.

Tembusan dikirim kepada yth :

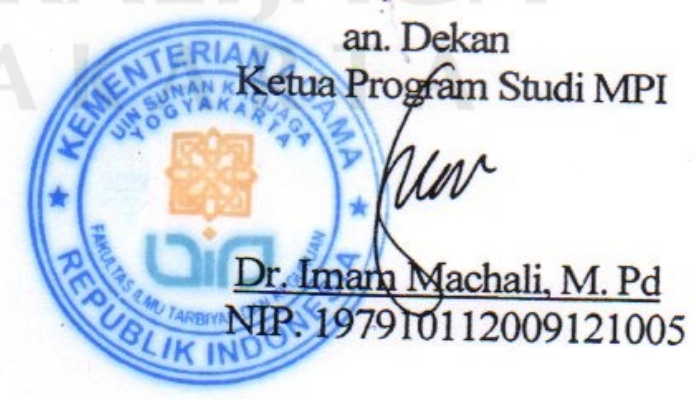

1. Ketua Prodi MPI

2. Mahasiswa ybs.

3. Arsip TU 


\section{KEMENTERIAN AGAMA REPUBLIK INDONESIA UNIVERSITAS ISLAM NEGERI SUNAN KALIJAGA FAKULTAS ILMU TARBIYAH DAN KEGURUAN}

Alamat: JI. Marsda Adisucipto, Telp. (0274) 513056, 7103871, Fax. (0274) 519734 http://tarbiyah.uin-suka.ac.id. Email: ftk@uin-suka.ac.id YOGYAKARTA 55281

\section{BUKTI SEMINAR PROPOSAL}

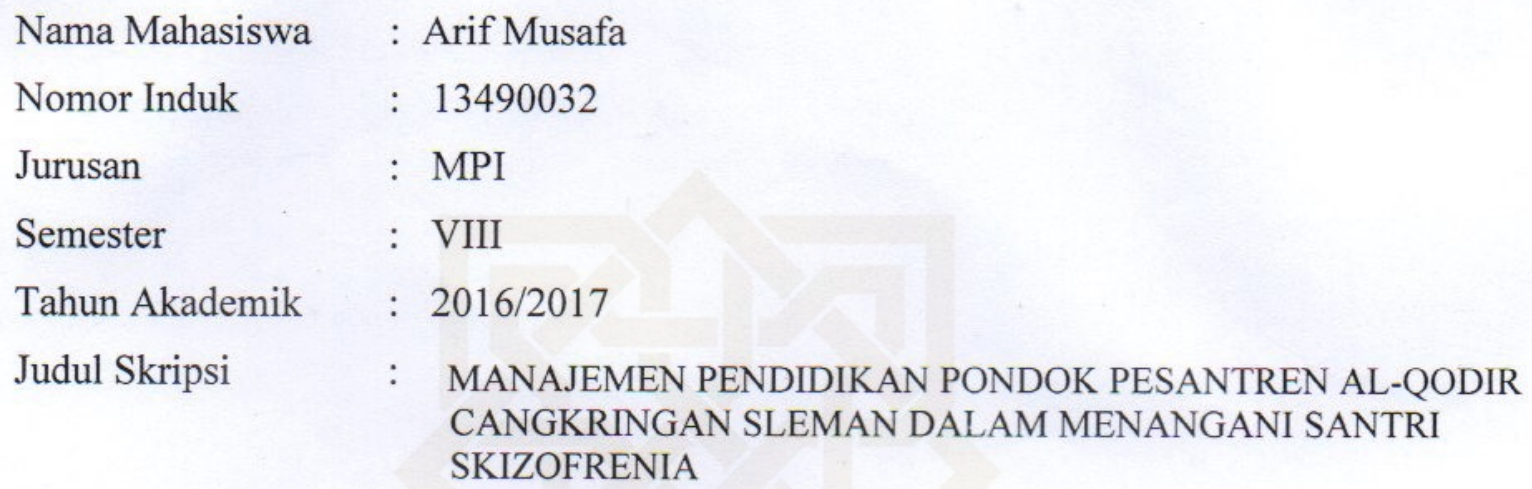

Telah mengikuti Seminar Proposal Skripsi tanggal : 9 Maret 2017

Selanjutnya, kepada Mahasiswa tersebut supaya berkonsultasi kepada pembimbing berdasarkan hasil-hasil seminar untuk penyempurnaan proposal lebih lanjut.

Yogyakarta, 9 Maret 2017

RERIAN Ketua Program Studi MPI 


\section{KEMENTERIAN AGAMA REPUBLIK INDONESIA UNIVERSITAS ISLAM NEGERI SUNAN KALIJAGA \\ FAKULTAS ILMU TARBIYAH DAN KEGURUAN}

Alamat : Jl. Marsda Adisucipto, Telp. (0274) 513056, 7103871, Fax. (0274) 519734 http://tarbiyah.uin-suka.ac.id. Email: ftk@uin-suka.ac.id YOGYAKARTA 55281

\section{BERITA ACARA SEMINAR PROPOSAL}

Pada Hari : : Kamis

Tanggal : 9 Maret 2017

Waktu $\quad: 11.00$

Materi : Seminar Proposal Skripsi

\begin{tabular}{|c|l|l|l|}
\hline NO. & PELAKSANA & TANDA TANGAN \\
\hline 1. & Pembimbing & Dra. Wiji Hidayati, M. Ag & \\
\hline
\end{tabular}

Mahasiswa Pembuat Proposal Skripsi

Nama Mahasiswa : Arif Musafa

Nomor Induk : 13490032

Jurusan : : MPI

Tanda. Tangan

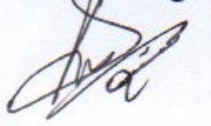

Tahun Akademik $\quad$ : 2016/2017

Judul Skripsi

: MANAJEMEN PENDIDIKAN PONDOK PESANTREN AL-QODIR CANGKRINGAN SLEMAN DALAM MENANGANI SANTRI SKIZOFRENIA

Pembahas

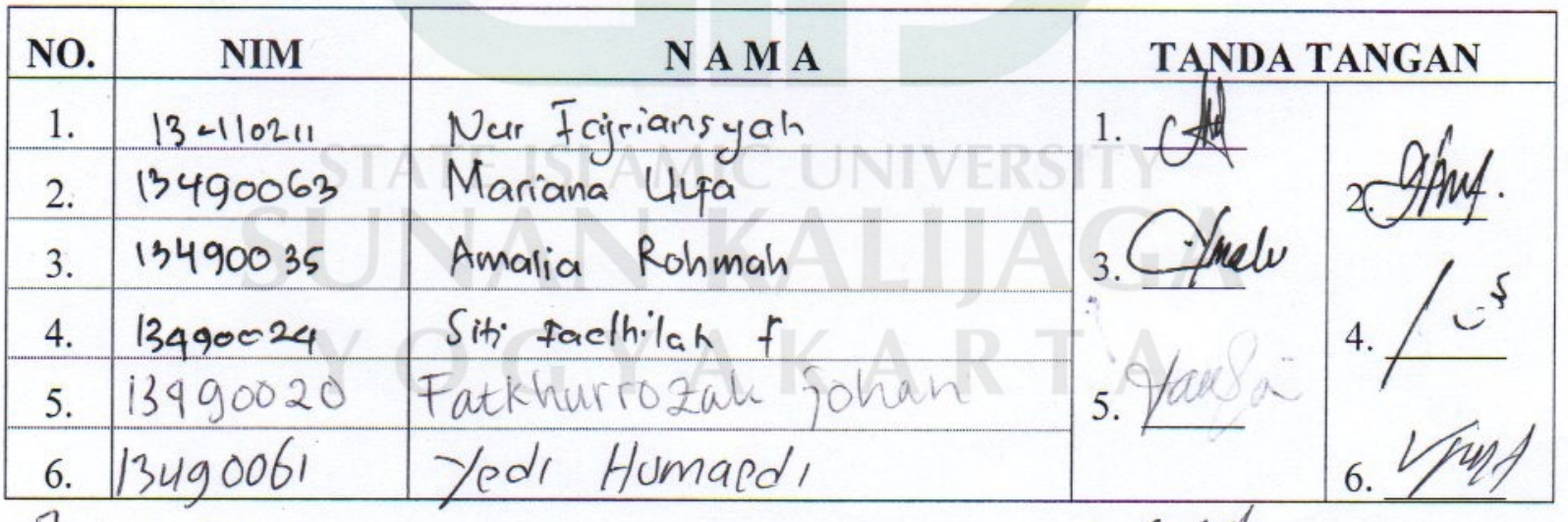

7. Bug0025 Basit Wuther $N \quad$ Yogyakarta, 9 Maret 2017

813490008 M. Latif basah

\%. 13490029 AF Rosyadi $<$

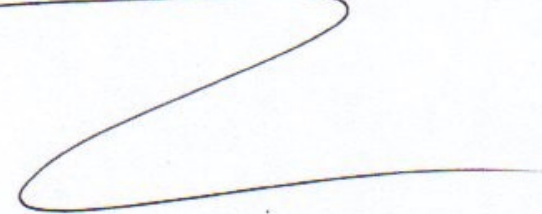

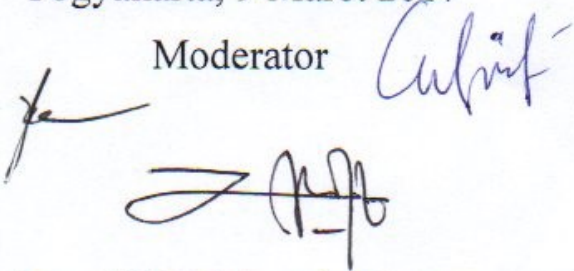

Dra. Wiji Hidayati, M. Ag NIP. 196505231991032010 


\section{KEMENTERIAN AGAMA REPUBLIK INDONESIA \\ UNIVERSITAS ISLAM NEGERI SUNAN KALIJAGA \\ FAKULTAS ILMU TARBIYAH DAN KEGURUAN}

Alamat :JI. Marsda Adisucipto Telp. 513056, 7103871, Fax. (0274) 519734 http:/ttarbiyah.uin-suka.ac.id/ E-mail : ftk@uin-suka.ac.id.YOGYAKARTA 55281

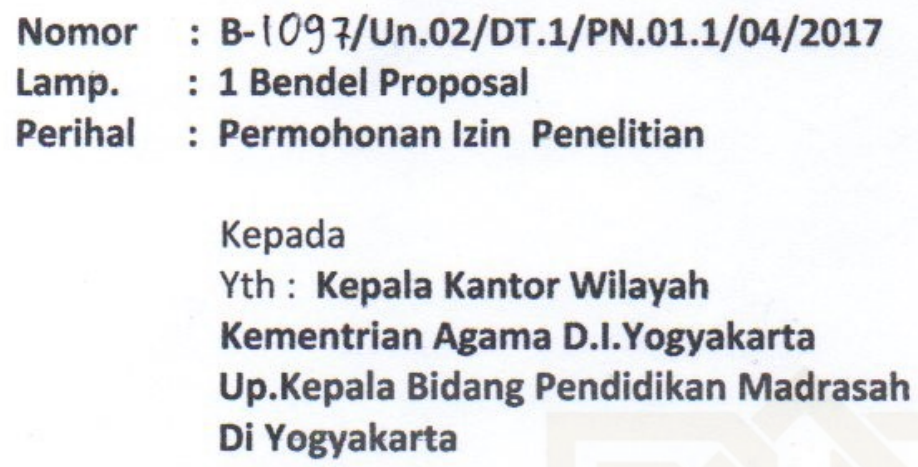

Assalamu'alaikum wr. wb.

Dengan hormat, kami beritahukan bahwa untuk kelengkapan penyusunan skripsi dengan judul :" MANAJEMEN PENDIDIKAN PONDOK PESANTREN AL-QODIR CANGKRINGAN SLEMAN DALAM MENANGANI SANTRI SKIZOFRENIA", diperlukan penelitian.

Oleh karena itu kami mengharap dapatlah kiranya Bapak/Ibu berkenan memberi izin kepada mahasiswa kami :

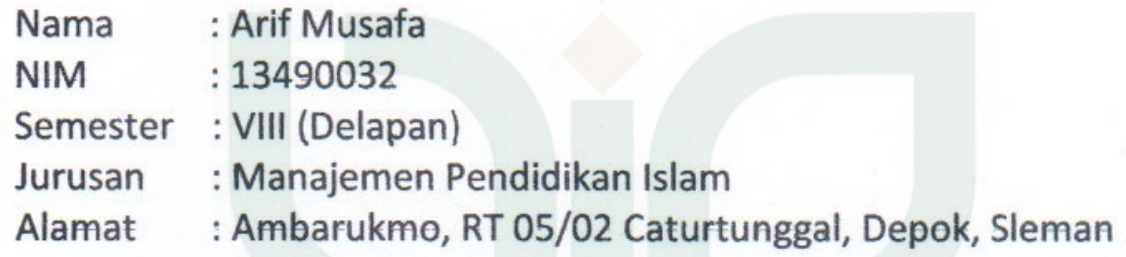

Tembusan :

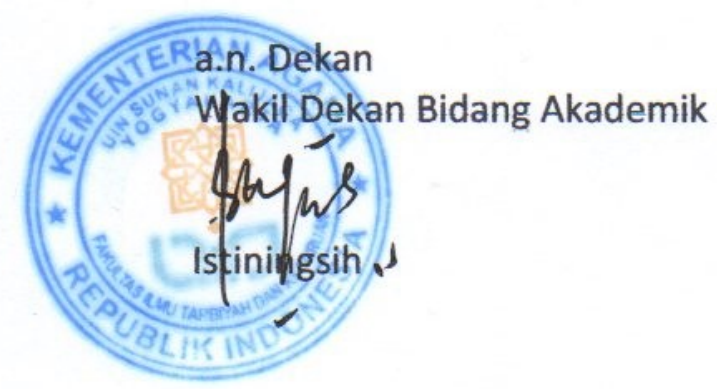

1. Dekan (sebagai laporan)

2. Kajur MPI

3. Mahasiswa yang bersangkutan ( untuk dilaksanakan )

4. Arsip 


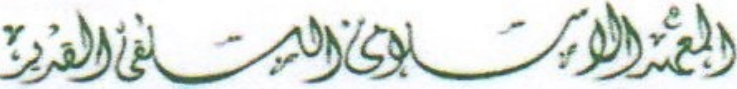

\section{SURAT KETERANGAN}

No : 07.I/SPb/PPAQN/2017

Yang bertanda tangan di bawah ini Pengasuh Pondok Pesantren Salafiyah Al Qodir menerangkan bahwa :

$\begin{array}{ll}\text { Nama } & : \text { Arif Musafa } \\ \text { NIM } & : 13490032 \\ \text { Prodi } & : \text { Manajemen Pendidikan Islam } \\ \text { Asal Perguruan Tinggi } & : \text { UIN Sunan Kalijaga Yogyakarta } \\ \text { Judul Skripsi } & : \text { Manajemen Pendidikan Pondok Pesantren Salafiyah Al-Qodir } \\ & \text { Dalam Mengasuh Santri Gangguan Jiwa }\end{array}$

Benar-benar telah melaksanakan penelitian di pondok pesantren Al-Qodir.

Demikianlah surat keterangan ini kami buat, semoga dapat dipergunakan sebagaimana mestinya.

Yogyakarta, 19 Oktober 2017

Mengetahui,

Pengasuh Pondok Pesantren Salafiyah

Al-Qodir
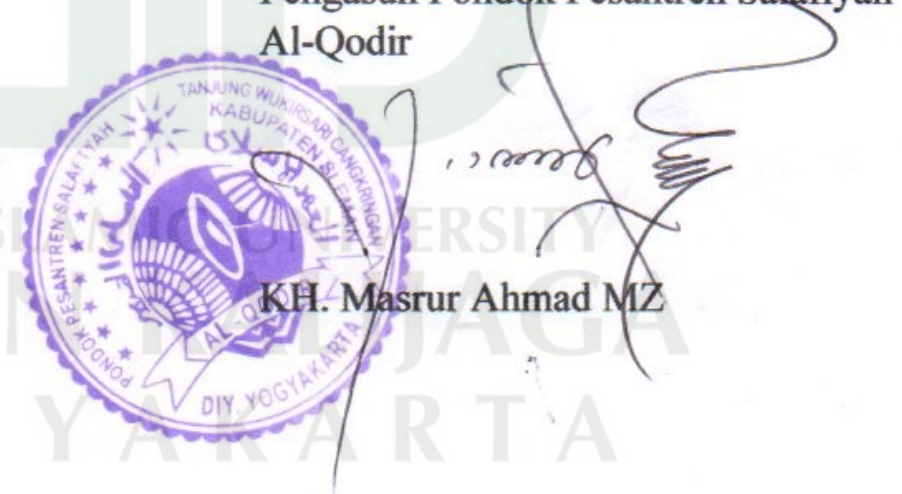


\section{Pedoman Wawancara di Pondok Pesantren Al-Qodir Cangkringan Sleman.}

1. Kapan PP Al-Qodir Cangkringan Sleman didirikan dan diresmikan?

2. Apa yang melatarbelakangi berdirinya pondok pesantren Al Qodir?

3. Bagaimana perkembangan pondok pesantren Al Qodir dari awal sampai sekarang?

4. Apa tujuan didirikannya pondok pesantren Al Qodir?

5. Ada berapa kamar di pesantren?

6. Apa saja kegiatan dan program pendidikan yang ada di pesantren Al Qodir?

7. Ada berapa santri yang di pesantren?

8. Bagiamana pendidikan yang ada di pesantren?

9. Kurikulum pesantren?

10. Bagiamana pembagian kelas untuk santri di pendidikan madrasah diniyah?

11. Apa saja materi yang di ajarkan di madrasah diniyah?

12. Ada berapa pengasuh di pesantren?

13. Bagaimana manajemen pengasuhannya?

14. Bagaimana perencanaan untuk mengasuh pondok pesantren $\mathrm{Al}$ Qodir?

15. Bagaimana pengorganisasian utnuk mengasuh pondok pesantren Al Qodir?

16. Bagaimana cara pelaksanaan pengasuh pondok pesantren Al Qodir?

17. Bagaimana cara pengawasan bapak terhadap bawahan?

18. Apa saja faktor pendukung dan penghambat untuk pengasuh?

19. Bagaimana manajemen pengasuhan santri gangguan jiwa di pondok pesantren Al Qodir?

20. Metode apa yang digunakan untuk mengasuh santri gangguan jiwa?

21. Bagaimana terapi untuk santri gangguan jiwa?

22. Adakah pantangan makanan untuk anak gangguan jiwa?

23. Apakah ada beberapa perkembangan dalam beberapa bulan?

24. Sudah ada berapa santri yang berhasil?

25. Bagaimana hasil pengasuhan tersebut, apa saja kriteria santri gangguan jiwa yang sudah sembuh dan bisa di pulangkan ke keluargannya.?

26. Berapa jumlah santri yang sudah sembuh dari gangguan jiwa dan pecandu narkoba? 


\section{HASIL WAWANCARA I}

Wawancara dengan Pengasuh Pesantren Al Qodir

$\begin{array}{ll}\text { Narasumber } & : \text { KH. Masrur Ahmad } \\ \text { Tanggal wawancara } & : 9 \text { Mei } 2017 \\ \text { Pukul } & : 15.30\end{array}$
A : Penulis
B : Pengasuh

A : bade tangled masalah pondok tentang gangguan jiwa?

B : kangge nopo?

A : tangled pondok niku tentang?

B : kangge nopo ko'!

A : ngge skripsi pak,

B : ohh

A : sing pertama niku sejarah berdiri pak, sejarah berdiri pondok.

B : lah niki mpun nopo dereng (sambil menyodorkan brosur pondok).

A : nggih mpun pak.

B : lah nopo judule sampean?

A : manjemen pendidikan pondok pesantren dalam menangani santri ganguan jiwa. Tentang pendidikan niku. Jadi teng nriki pendidikane seperti apa. Kan kulo tanya kang ibin kan tidak katanya kan tidak membedakan santri yang biasa santri yang gangguan jiwa. Dari segi pendidikan santri gangguan jiwa kaya hidup bareng, ngaji bareng kaya biasanae. Niku kaya kurikulumnya seperti apa. 
B : Pondok pesantren apa ada kurikulum. Pondok pesantren ndi sing enek kurikulum. Kurikulume nek nganggo kurikulum nek sekolahan. Nek pondok opo enten kurikulum.

A : nek materine enten nopo mbten?

B : nek materine yo materi agomo koyo pondok biasane yo enek ngaji.yo ngoten-ngoten niku.

A : nek penerimaan santri sing biasa kalih gangguan jiwa niku benten nopo sami?

B : podo mawon.

A : oooo nek syarat-syarate mlebet niku nopo mawon pak?

B : gelem. Nopo maleh?

A : nek metode kados penyembuhane niku kados pripun.

B : terapine nek butuh obat golek obat, nek ra butuh obat yo di dongake dongake. Nek butuh di dus.i yo di di dus.i, melihat keadaane pasien. Melihat penderita gangguan jiwa itu

A : nek narkotika niku nganggene nopo pak, obat sing ngangguan narkotika.

B : nek narkotika ora nganggo obat mas, malah leren. Ora diobati

A : nek narkotika nganggene nopo?

B : wiridan. Kegiatan sesuai kebutuhannya, gitu aja

A : sing lintune gangguan jiwa niku biasane nopo?

B : macem-macem yo neng sawah, kandang, nukang, ngingu bebek, bengkel, tergantung kesenenge oleh dia.

A : nek faktor-faktor penghambat dan pendukung niku nopo mawon pak biasane niku? 
B : nek sing penghambat nek sing bocah terkadang kalo orang gila pake obat orang gilanya males minum obat. Terus di kasih kegiatan tidak begitu belum begitu menemukan apa dia suka apa yang dia mau. Itu agak paling lama itu mencari kamu itu senangnya apa, itu loh. Dari kesenangannya itu dia. Itu yang paling itu

A : nek dukungan keluargane enten pak?

B : ya jelas. Orang gila orang narkotika itu kan banyak banyak unsur sembuh butuh dukungan. Disamping dirinya itu yang paling utama, dukungan keluarga dukungan lingkungan dukungan aturan-aturan. Disini aturan negara juga dibutuhkan.

A : Kalo misalnya mendet apa ya tahu udah sembuh atau enggaknya itu seperti apa pak?

B : kalo sudah tidak kaya orang edan ya berarti wes waras. Kalo saya yang jelas satu karena saya orang pesantren walaupun dikatakan orang oleh orang mungkin gila mungkin tapi kalo orang pesantren ya kalo sudah umum sama temen-temennya. Terus ngaji juga sudah umum sama tementemennya. Terus kegiatan-kegiatan makan, tidur tidak diajari. Ya sudah itu

A : kalo kontrol njenengan niku setiap dinten nopo setiap minggu pak?

B : kalo saya setiap hari, terutama kalo malam jum'at saya selalu ngontrol salaman tapi setiap hari kan ikut sorogan, gaya bicaranya lihat dia kan disitu gaya duduknya, wah ini duduknya masih kaya orang gila, kan itu memang gitu-gitu

A : biasane paling cepet niku pinten pak wekdale?

B : macem-macem ada yang 11 hari selesai 40 selesai ada yang bertahuntahun disini tidak tidak sembuh-sembuh gitu.

A : kulo kan pas tingali video yang diliput di Tans tv dan TV One niku kan kang Kbin sami, niku kenene nopo pak? 
B : kan dulu di rumah karena mungkin tidak nyaman di rumah akhirnya menggunakan obat obatan. Apa lagi.

A : kan biasane mpun mari di balek.e teng ndaleme apa tetap di sini pak?

B : enten sing teng mriki terus, eneten sing muleh. Yo macam-macam, Kaya kang Ibin sudah 10 tahun, terus dia sudah mau nikah. Sudah ngomong kalo nikah di rumah aja. Ya monggo masa gak boleh

A : kalo tak tingali niku sing dados pengurus kang Ibin kang Adi malah sing saking niku, nggih. Niku sing ngurus gangguan jiwa jumlahe pinten pak?

B : biasane tiap anak ada dua anak yang ngurusin. Apalagi nak?

A : nek teng mriki peraturane biasane pripun?

B : peraturane ya gak beda, gak peraturan-peraturan yang baru. Peraturane gusti Allah. Aturan-aturan itu sudah tidak bisa dirubah aturan yang paling baik saya gak pernah nambah aturan

A : kados pearaturan kados santri ijin kados nopo niku sing teknisnya?

B : oh santrine ijine arep mulih ngono ya, biasane ngomong pamitan sama saya katanya dia saya yang punya pondok katanya dia, dia menyampaikan mau pulang yo pulango. Saya gitu

A $\quad$ : sing biasne ngatur jadwal ngaji niku sinten pak?

B : nek ngaji yo kaya biasa, nek diniyah bocah-bocah pengurus kulo ra ngerti

A : nek pengasuhan saking bapake niku pripun pak?

B : maksude?

A : dados bapak ngontrol larene setiap minggune..

B : oh kui setiap hari ngaji, sorogan, satu Satu.

A : biasne niku sorogane nopo pak? 
B : Al Qur'an, sedapatnya mulai habis sholat ada yang baca Qur'an ada yang baca kitab ya macam-macam yang penting dia maju absen madep saya yang penting dia ngaji, kabeh kan gak podo ada yang satu halaman 


\section{HASIL WAWANCARA II}

Wawancara dengan Lurah Pondok Pesantren Al Qodir sekaligus terapis

Narasumber $\quad$ : Muhammad Muqorrobin

Tanggal wawancara : 19 April 2017

Pukul : $15.30 \mathrm{WIB}$
A : Penulis
B : Lurah Pondok

A : niku kan rencanane kan niki badhe penelitian tentang manejemen pengasuhane niku kang.

B : ohw manajemene.

A : nggih pengsuhane.

B : neng ken era enek manjaemen e, penagsuhane neng kene ki, yo enek neng kene ki pak yai ra njaluk bayaran. ep menajemen piye?

A : kalih kados perencanaane niku pripun kang, kados perencanaan penyembuhanane pripun? Kados sing ngasuh sinten mawon?

B : bedane neng kene karo rumah sakit jiwa karo rehabilitas mungkin itu beda sekali, nek khusus rehabilitas namanya khusus rehabilitas. Jadi harus tahu dulu pesantren salafi al Qodir ki opo menurut anda itu gimana?

Nek bapak mengartikan pondok salaf itu seperti toko klontong, toko klontong kan golek opo wae ono, lah disini di al qodir juga sama, ep golek cah sekolah enek, wong apal, ep ngaji kitab tok ya ono, ono wong narkoba. Wong edan juga,satu komplek. Trus manajemennya gimana? Mungkin bayangan anda bagian pengurus sing ngurusi ki orang gila narkoba sendiri, jadi kan nek sudah di skat-skat, lah di al qodir satu komplek, nek di skat skat pie, mangan bareng, kamar satu komplek, kegiatan podo. 
A : mboten enek sing khusus?

B : secara khusus tidak ada, pak yai menerangkan terapi kan memanusiakan manusia, dibaurkan-baurkan dengan orang waras yang okeh sing wong waras secara kehidupan riilnya. Ep manajemen secara pie manajemennya? Mungkin bayangkan anda ki harus dimanajemen khusus dewe ngene, makan sekian, opo ben sehari ki per anak kudu makan kudu kegiatan opo secara manajemen secara detail ya susah. Sampean urip neng di kampung, dengan heterogen opo karekter orang pegawe, swasta, opo dengan satu sistem berjalan?

A : tidak

B : tidak, opo menggunakan satu sistem untuk mengelola tersebut, sedangkan orang itu sangat multi heterogen, yang memgang tidak mungkin satu satu trus gimana caranya, ya ini al qodir kan. Saya itu santri ya saya di pasrahi momong, lah saya trus al qodir orang opo sing untuk rehabiltas harus mennagani satu karena saya tu menangani tu karena dapat mandat. Dan saya ngga pernah membikin iklan, engga pernak. Al qodir juga gx pernah bikin iklan. Lah mengatakan satu secara prosedurnya itu tetep yang punya pondok kan pak yai, pak yai yang momonga. Yang membikin aturan adalah pengurus untuk kegiatan itu berjalan. Pengurus membuat aturan-aturan itu secara prosedurnya itu gx mungkin prosedurnya anak sekolah dengan pasien itu sama.

A : prosedurnya pasien itu pripun?

B : satu, dia harus mau dulu, kalo gak mau gak kepaksa-kepaksa ngapain. keadaannya terbuka kaya gini. Pokoknya dia mau dulu, mau gak. Kalo gak mau ko’ dipaksa.

A : kalo ciri-ciri wes sembuh ki pie kang? Wes mari? 
B : ciri sembuh ki ya macam”, orang menafsirkan ki macem-macem. Umpamane wong wes sadar di anggep wes sembuh Karena namanya kesembuhan itu kan relatif kan orang orang menyembuhkan rehabiltas bilang itu udah sembuh. Makannya dikasih bahasa gini, mbok semua rehabilitas mbok bentuknya pondok, Rumas Sakit Cuma 30\%, 70\% itu dimana? Ya keluarga sama pasien itu sendiri. Saiki enek wong bingung trus ngelantur trus sadar gak harus halusinasi. Apakah itu dikatakan sembuh. Bisa iya bisa tidak. Bisa iya berarti tidak halusinaasi. Loh ko' di rumah tidak kambuh lagi? Ngono lo. Jadi penafisran sembuh ki macam-macem. Sembuh juga bisa. Tergantung orang yang menasirkan sendiri sembuh yang gini. Makannya koyo coro logikanya orang wong awam nek pengin ngerti iki nek koe ki iso ngerti carane mandi koyo awak e dewe ki q tak jamin kui wes mari. Ra sah adoh", koe ngindik dia mandi secara diri kita wes tak jamin wes sembuh. Yang adus awake dewe yo sikatan yo madi koyo awake dewe merata. Kalo bisa mandi seperti kita saya jamin sudah sembuh.

A : kalo secara mentalnya kang?

B : karena mental kan karena, dibalekan flesh back meneh, ki edan karena apa, asal muasalnya. Berarti ada kan memikir cabange ki ngebleng. Berarti gx tau kenapa bisa ngebleng. Anda harus menggolei kuine. Nek pengin meneliti ya harus mencari dulu kenapa sebab.e opo karena dia ngebleng karena halusinasi. Kenapa halusinasi karena gak tidur karena dia mikir, mikir opo? Itu kan, makannya yang sangat tau banyak tidak nya kan keluarga.

A : kalo kebanyakan disini karena apa kang,

B :ya itu semuanya kan saiki pengalamanku sampai 2005-sekarang itu gilanya Cuma setengah-setengah.

A : setengah-setengah berarti stres ya kang. 
B : stres ki edan ki ora tenanan. Di bilang gila ko ya nyambung tau, dibilang ko waras ko kan edan.

A : Kalo dulu tak lihat itu kang sering ngomong dewe ngono lo kang

B : ya kalo ngomong dewe, kalo di ajak interaksi kalo dikasih membedakan ini uang 5000 sama 10000 memilih mana tetep yang lebih besar. Hanya itu setengah-setengah kalo orang gila pa tau, dikasih telek sama ikan apa bisa mbedak.e. kei godong karo opo ya pangan kabeh. La itu bedane karo saiki. Kadang di kamar ketawa sendiri. Tapi rokok dikasih rokok yang enak dengan dengan gx enak milih yang mana, dikasih tahu apa ayam, pilih ayam. Yo karena td ngelantur karena dia gak tidur, kenapa gak tidur karena dia itu mikir. Apa yang dipikirkan yaitu kan, opo nek ra turu nek bisa ngono kui, dia gak tidur bukan trus ra turu 2 dino trus ngebleng ki ora. Biasanya dari rumah sudah parah. Setahun kadang 5 tahun, bearati yang susah itu tu gimana nek wes maune dia kalo kebentur masalah trus tidak ngebleng itulah mbene mari. La sek saiki nek genah orang gila ki ngebleng karena oh karena ki masalah dee mbojo bojone calon bojone ki wes dirabi wong, nah semacem itu. Kalo lainnya, lah saiki nek anda mensurvei ki tak omongke 5 tahun ki orang gila itu karena kasih asal muasalnya bukan karena satu, memang dinamiknya karena asmara, tapi karakternya yaitu terbentur karena dia tu kasih atau kurang perhatian. Dengan coro bahasana manja lah. Membikin kareakter manja tu bukan wes gede trus dimanja dari kecil itu dari keluarga, dia gak menyadari. Orag manja gx memandang orang tu kaya orang tu miskin. Tak kasih contohnya ngene ki. Waktu punya anak tu saking senenge opo-opo di di kaya kesenngannya opo wae orang batas sampe mau menginjak remaja. Trus lebih parah lagi kalo nyampe yang waktu kecil dia mantu manjanya melebihi orang tua. Itu kalo anda sebagai itu bedanya anak dimomong orang tua sama kakek tu manjanya gimana, lebih manja dari orang tua. Dan itu berjalan sampai remaja waktu SMA lah setelah itu dia mau mandiri tu dah gak bisa, semula biasa di dulang biasa di cukupi lainnya 
pada gak mampu dia bingung, akhirnya biasanya trus tertekan dia pengin ini kurang banyak macem-macem efeknya. Kaya mungkin ada depresi trus opo tekanan minta. Mungkin ada bayangane pas kui aku ya pernah asal muasale ngono kui, trus biasane trus ngeblenge ki pie, ya nek anda modal kuat cukup ono waras, lah permaslaahane kui lah sing susah kan ngono kui. Nek manja sudah tau oh karena asalnya manja maka mikir karakternya orang manja tu gimana? Orang manaja tu gimana? Orang manja tu rajin opo orang manja tu opo bisa opo o e orang manja opo jenengen memaksa diri opo orang manja tu orangnya fer, tergantung kalo anda tau pasti orang maanja tu satu, pemalas. Kedua gak mau di salahkan yang ketiga kalo punya keinginan harus. Lah karakter 3 itu yang membikin susah kalo memberikan akhirnya kalo udah akut bertahun-tahun kaya gitu akhirnya dia halusinasi ingin dadi dia harus minta di ajak ayo makannya mengatasinya dengan dokter, dengan kalo gx istirahat total tu tidur apa udah jaminan ya bener penyakitnya sudah sehat setelah sehat apakah dia mau sudah aktivitas, karena manja itu tadi. Kalo gak ada aktvitas gak ada obat dia ngalamun lagi, ngebleng lagi. Oke cara fisik, gimana caranya itu biar dia itu gx kalo halusinasi kita alihkan dengan kegiatan. Kalo dia tidak gak punya sifat pemalas gak over pasti gampang kalo malas pasti gak ada opo di suruh banyak alesan karena seperti itu susah. Jadi komplek kalo saut menyaut, lah anda tidak, penginnya langsung instan tak tanya dokter obat untuk pemalas itu apa? Borong semua obatnya?

Lah itu kalo kunci pokoknya kalo anda pengen meneliti obat pemalas itu apa. Kalo nanti anda pengin tau karena smbuh ini apa, ya oke karena sembuh ini satu, kalo menghilangkan halusinasi itu gampang. Tapi untuk untuk dia tidak terbentur masalah ya dengan halusinasi lagi. Itu tadi, penyakit malas, obatnya malas itu apa? Kalo sudah ketemu obat malas mari penyakite wong edan sing kui. Haa itu kalo menurut saya dari survey dari tahun sampe sekarang. Ya karena itu. 
A : biasane kegiatane opo kang? Kalo mengatasi itu semua?

B : lah iya obatnya malas. Kita juga punya penyakit malas ya aku tidak membeda-bedakan sama seperti saya, kan waktunya ngaji ngaji, secara terapi khusus terapi khusus apa wong dia sawah ada bengkel ada wong namanya malas di suruh gini kan makanya anda bayangannya langsung menjurus itu lo kegiatannya apa berarti obat pemalas. Cari dulu obatnya mala situ apa. Kan pada sama sampean. Kan itu. Tak balikin kan mengejar saya apa apa secara apa terapi apa biar dia itu sembuh dari aktivitas tadi kan tak balikin kepada anda bagaimana caranya mengatasi orang malas. Tanyakan aja beda, semuanya orang males. Ya harus bekerja harus banyak kegiatan, kegiatan apa tak tanya. Jadi terapinya itu fleksibel. Fleksibelnya itu secara kegiatan ya senengnya apa sampe digituin. Untuk dia memompa motivasi itu senengmu opo? Ndak punya kesenangan kegiatannya apa sawah ra tau kerja, lah penyakite ki pengine punya uang bisa ngopi ngrokok ngopi ngrokok ngantek apal. Lah kepiye carane ngono kui. Kerja gx mau banyak alesan capek, sakit lah itu gimana kalo gx ada kegiatan nanti gak tidur satu hari dua hari nanti ketawa, lah itu tak kasih gambaran kaya gitu. Gak Cuma anda yang lainnya penginnya instan. Obat terbaiknya apa, ya cari obat penyakit mala situ apa borong kabeh obate. Lah itulah yang sekarang terjadi kaya gitu

A : tapi kalo buat kaya ngaji trus dzikir itu mau kang?

B : loh kamu jangan salah orang yang setengah-setengah kenceng ngajinya.

A : iya to kang??

B : lohh tak suruh baca qur'an nyambung, faseh berarti kenapa kang ketawa, tidak lazimnya orang normal, kaya tidak tidur. Tapi kalo dipaksa baca qur'an, jangankan baca qur'an kasih hal yang riil saja, masalah makanan tadi itu loh, kasih tahu sama ayam, pilih ayam. Kadang makan tahu purapura gak mau, kasih yang enak baru makan. Ya itulah tak kasih gambaran 
mengenai karena asal muasal karakternya orang manja itu lo. Wes kamu gak usah mikir werno-werno nek iki wong manja ngatasi wong manja itu gimana? Itu orang manja. Padahal kalo udah gede itu bisa beraktivitas seperti diri kita. Tak usah dikasih yang berat-berat kalo bisa mandi seperti kita berarti wes sehat, njajal wong gitu susah loh wong manja hal sepele mandi bak byuk byak byuk kongkon wong manja mandinya susah keduanya kalo sudah mandi malah buat mainan lah trus mengatasi wong manja itu tak balikin mengatasi wong manja itu pake kegiatan. Kegiatannya apa? Wuhh banyak sekali anda maunya gimana gak bisa pake teori pake ini! Gx bisa karepe wong beda-beda.

A : berarti senenge wonge ya kang?

B : ya itu untuk memompa agar dia tidak males itu gimana ngono lo intinya gitu lo. Gak usah jauh-jauh diri kita sing waras wae pasti punya penyakit males kalo kita gak seneng pasti yo ogah-ogahan. Gimana awake dewe biar seneng itu gimana? Tadi dibalikin gimana mikir orang lain biar seneng itu gimana, kegiatan itu. Lah itulah carane tak kasih gampang nek anda meneliti kaya gitu. Terapi khususnya ya apa, ya secara alamiyah.

A : di daerahku kan ada kang di daerah ambarrukmo, satu orang opo kerja di AMPLAZ di moll, dia kredit motor trus kena masalah pelecehan seksual itu loh kang kadang nyolek atau apa trus dilaporin ke bosnya, trus dipecat kan tidak punya pekerjaan trus kredit motornya diambil sama delear. Trus stres kang stress, ya hidupnya gak karuan dan hidupnya kurang diterima sama masyarakat itu loh kang.

B : emang semuanya kaya gitu, dia punya keluarga?

A : punya, tapi tidak diterima sama keluarganya.

B : makanya tak bilang tadi itu loh namanya punya masalah kamu jangan mikir pas kejadian itu, semuanya. Aku mikir semuanya gagal tes, trus pas tes ngebleng jangan itu, terlalu simple. Makannya anda sarjana kalo mikir 
sampe segitu ya goblok sekali. Kenapa pondok pesantren hanya $30 \%$ dan $70 \%$ dari keluarga. Makanya tak bilang kalo Cuma masalah materi mungkin dia pengen kaya, pengen punya motor, pengen punya duit banyak, dia bisa menahan. Tapi secara apa ya tapi secara realita, dia pengen punya motor pengen pengen punya mobil pengen, dia pengen bekerja tidak berat di kantor pengen, kan bisa menahan, tapi bikin dinamit meletus ngebleng dia itu biasanya yang sampe dinamitnya meletus ngebleng itu karena suka lawan jenis. Lah asmara itu saking gak kuatnya ngebleng gak kuat. Dia mikir trus ketambahan asrama itu bleng ngebleng. Dia pengen pekerjaan, ngamuk pengen dibelikan motor. Nek anda pengen menelusur kenapa dia pengen pekerjaan, pengen punya motor ya satu untuk mendekati lawan jenis. Lah tak kasih bantuan itu,

A : emang tak lihat-lihat ya itu cuma satu pengen pendapatkan pekerjaan untuk mendekati lawan jenis.

K : lah iya makannya kamu jangan mikirnya sepotong-sepotong, iki habis di pecat ko gila lah itu anda harus tahu seluk beluk dari si A itu apa si A di tanya pasti gak tau kuat kadang-kadang gak mau terbuka. Lah dengan itu tahu itu asamara, lah kamu tahu ndak karakter orang itu. Karakternya orang itu pekerja ndak, oke dibikin pekerjaan kasar biar pagi siang sampe sore bekerja cape biar malam bisa tidur kan gitu. Kalo karakternya orang manja gak mau kerja yang berat, apa obatnya. Kerja disana ditolak kerja disana ditolak trus diapain? Ya itu kuncinya satu kalo pengen kaya gitu ya jangan merasa bosen. Yo seperti anak kecil baru mau jalan kaya gini duduknya kaya gitu gak boleh kalo gak boleh kan ngambek kalo ndak rewel ya enakenak wae. Lah saiki mikir positif dikasih obat ini bar langsung sembuh ya cari gusti Allah wae sana, udah selesai itu. Lah keluarganya udah menolak sudah gimana lagi wong asal muasalnya dari keluarga.

A : saya juga bingung bagiamana caranya masalahnya dia juga kepentok keluarga dan kerja disana kemari tidak diterima, soaudara juga ndak nerima. 
K : lah iya yo pasti. Yo makane secara teoritis dia setengah-setengah, diajak ngobrol dia nyambung. Makannya itu yang sudah itu ya opo ya memberi pengertian kepada kelauarga, lah di rehalbilitas Cuma 30\% di luar keluarga $30 \%$ mentok. Kalo sudah sadar ya hanya sampe situ nanti diluar area anda ya bleng lagi, nah gitu kan nek dilogika kan ngono logikane ki. Gak ada logikane psikiatri mana yang tidak membutuhkan keluarga pasti membutuhkan keluarga, mustahil. Kadang aku yo sampe bosen ditanya ginigini setiap fakultas apa ya sama-sama mungkin melihat orang lain kasian mau diapain. Wong kita sebatas menolongnya kan tidak utuh, nantinya lempar sana lempar sana iya kalo dia itu mau kalo gak mau. Saya apa kalo mikir mung cabange mung kui tok gak mikir asal muasalnya ya itu tadi kaya jamur ini ada jamur pangkas tes tumbuh lagi pangkas tes ya itu tadi kalo gak nyampe akarnya gak tau akar muasalnya di otak atik yo ngebleng. Ya kalo pengen menolong itu gimana, ya dikasih pengertian tapi juga ada perubahan si pasien, dia dituntun berubah keluarga dituntun untuk berubah bisa mengeklopkan. Itu bisa menolong kalo anda seperti ini sama seperti pihak rehabilitas sama lah itu gak usah rehabilitas keluargapun bisa asal yaitu tadi mau berubah semua tau cara akar asal muausal oh begini trus dimusyawarah bagiamana caranya manusia punya po ora, wong kewan punya filling kudu diperhatikan opo neh manusia ngko iki nek over perhatiannya malah manja step by step tidak secara instan. Makannya satu psikiater pasien jangan merasa bosen ko nyampe keluarga aja udah bosen ya repot akhirnya kan banyak modus taruh sana biar pinter ngaji tur gini-gini, aslinya udah bosen, gak satu dua kaya gitu. Jadi kalo secara opo ya mungkin anda penelitian mikirnya keluarga harusnya yang berusaha pengen menyembuhkan tapi sudah beda jalur. Tapi dia maksudnya pengen menerapi tapi bukan menerapi karena sudah bosen ya beda lagi masalahe itu sudah terbukti dari sekian tahun. Makannya mau di teliti si pasien udah ngebleng sama keluarganya malah sampe ajal ada juga disitu.

A : ada? 
B : ada, kalo di pondok itu kalo orangtuanya maunya gimana karena sudah bosen ya banyak dalilnya di rumah ngamuk-ngamuk gini gini-gini, trus apakah menurut anda sebagai peneliti itu sudah jalan terapi? Hihi makannya tak balikin seperti itu karena anda membahas penelitiannya secara teoritis yang notabene dari keluarga ikut tercampur, nah itu dari induknya aja gak ikut campur trus gimana trus penelitiannya gimana, tak balikin gitu, apa kita ikut modus-modusan penginnya gini, kalo secara manajemen gak pernah matok penginnya segini, itu pak yai gak pernah bilang kamu nginep sebulan bayarnya sekian-sekian malah aku sebagai pengurus yang bikin wong mau mengatakan apa, kalo mau ngaji silahkan, kasih pondok kasih ke pak yai, mau ngasih kebutuhan dapur kasih ke bu nyai, mau ngurus kegiatan seharihari oke dia belum bisa kasih ke pondok, gitu kan, nominalnya berapa ya gak tau, wong itu secara manajemen keuangan. Itu bahas gitu aja udah repot sudah melangkah kaya gitu melangkah secara terapinya udah kaya gitu, jadi kalo ketawa sendiri ya bingung, itu dijadikan terapi pondok karena sudah pada pusing. Durasinya dia ngebleng tidak hanya satu tahun dua tahun loh ya yang dibawa sudah akut semua, maksudnya akut sudah dibawa ke suralaya sudah bawa ke rumah sakit kalo ngomong sampe jadi jenuh aku ngomong ya karena satu kalo sudah kantongnya sudah tipis secara materi, kedua karena di keluarga sudah bosen ngadepin kaya gitu terus dia ngamuk terus, trus dia dibawa ke pesantren biar bisa ngaji trus dia seperti orang umunya bisa pekerja pulang bisa mandiri kan enak to, kamu jawabnya gimana kalo ditanya kaya gitu, lah kita sudah semampu kita kuatkan udah kita alihkan udah nyambung disambungkan ke keluarga keluarga tidak merespon. Udah bagus udah nyambung malah keluarga bikin ulah lagi, oh ini udah waras sekarang dibahas akar muasalnya di keluarga gimana, dia pengennya ya pengen kerja makannya nyambung gak udah kamu ngaji dulu ya repot lagi, ngebleng makannya enak-enak aja dirumah, jadi ibarat naruh orang kaya naruh motor dibengkel wah ini rusak naruh motor di bengkel wae tak pasrah bengkel tak otak atik udah selesai tinggal naikin karepe 
ngono, lah iki manusia dan penyakitnya iki 90\% penyakitnya dari keluarga, makane aku ngomong bukan karena teori dari tanya, anda kan orang teoritis orang jiwa itu opo gangguan jwia itu sampe tak tanya pengertian gangguan jiwa itu bagiamana secara teoritik?

A : Ya bisa dari lingkungan bisa misalnya dari kerja kan saya nemu dari kerja.

B : ndak pengertian secara teoritik gangguan wong stres atau jiwa iku pie umumnya apa? Orang jiwa adalah orang yang mengalami opo ngono lo nek secara teoritisnya gimana

A : ya nggak pada umumnya gak diterima oleh masyarakat.

B : lah patokannya tidak diterima oleh masyarakat itu apa bila dikategorikan orang itu gila.

A : gimana ya

B : makannya orang gila itu ketawa sendiri, pas jam-jam itu pas ada yang ngasih berbagi pilihan ko milih seperti orang waras, kita kasih lagi perbandingan yang beda lagi pilihan itu ko seperti orang waras, apakah itu kategori orang gila? Jadi anda tak katakan tanya teori anda lihat orang katawa sendiri pas tidak ngalamun dia sukannya ngrokok kasih rokok 76 sama djisamsoe pilih mana oh pilih djisamsoe dikasih makanan dikasih makanan yang paling gak enak sama makanan yang sedeng sama makanan yang paling enak pilih mana atau dimakan semua nah itu nah sekarang kamu survey orang gila yang dipinggir jalan itu dikasih semuanya apakah dia milih lah itu makannya kategori teori anda nek orang gangguan jiwa itu yang mana dulu kalo gangguan jiwa seperti di jalan itu gak bisa mikir apa-apa ditertawakan itu orang gila original.

A : Kalo yang di teori kan ini kang skizofrenia nah jadi lebih kepada tekanan keluarga, hubungan kerja gitu kang spesifik disitu. 
B : lah iya makannya itu tadi sudah bilang, sebelum meletusnya ngebleng sebelumyna dia masih normal lihatlah karakter anak itu seperti dia manja atau tidak. Orang melihat manja itu macem-macem loh dia gak manja madiri gini gini gini. Kan lihat dulu karakter anak itu kalo dia itu mau bekerja kasar itu lebih gampang, kalo dia belum pernah bekerja berat itu ya gitu, contoh simple gini kerja kasar bukan berarti macul, tapi punya aktivitas misal di kantor punya disiplin ada, trus penyakit kanker itu keadaan tubuh pemaksaan diri dipaksanakan mandi trus kena kanker kan ada keras. Kalo aktivitas manja disuruh sebelum dia ngebleng loh, mau makan disiapin lah terpupuk dengan kebiasaan itu lah nanti kalo ngebleng itu merubah kebiasaan dicukupin, biasa siapin itu merbuah itu juga. Ya itu yang berat padahal itu kuncinya untuk mengaplikasikan halusinasinya pada kehidupan. Sebelum nanti anda membahas nanti itu tadi apa psiko apa?

A : skizofrenia.

B : nah skizofrenia itu kan itu kan cenderungkan ke pasien dan keluarga. Lah untuk mendorong selesainya masalah itu dengan keluarga itu loh. Aku ki sifat karakternya kalo manja sih. Pada sih gambaran yang gampang itu mau bekerja keras sambil menyambungkan dengan keluarga itu aktivitas keluarga itu sudah capek mesti masa kalo kerja juga gak nerimo. Lah bagaimana aktivitas yang gak capek itu gimana habis sampe sore, jalanjalan juga dia kerja, dia bersih-bersih nyapu, lah karo orang manja nyapu 10 m udah nyapu aku udah cape kalo secara lazimnya menyapu apakah itu sudah cape lah gitu lo makannya tak tanya kegiatan itu aktivitas yang dia kerjakan itu lazim apa tidak itu yang jadi persoalan sekarang lasimnya orang bersih-berish itu gimana, lazimnyadia beraktivitas itu gimana kalo dia sudah lazim semuanya kegiatan aktivitas aku jamin kan gampang sembuh secara fisiknya. Lah psikisnya tadi yang jadi masalahnya adi itu loh trus ujungujungnya masalahnya asmara tadi. Lah itu loh jangan langsung ke atas dulu, yang dasar aja belum, anda mikirnya gitu iki pasien biar sadar gimana gitu 
yaitu cari aja obat pemalas itu apa, kalo kamu bisa mencukupi kebutuhan dia saya yakin dia waras, itu gak usah kerja butuhmu opo cepak.i, waras pengen coba coba wae. Siapa yang mau nyukupi materi semuanya gak mau wong aku bukan keluarganya ko. Lah itulah hal-hal yang kono kui wong dibahas sing kepie nek ngono kui, tapi masalah keluarga juga. Kalo penelitian yang semua yang umum seperti anda kan seperti keluarga tidak masalah ah itu kan keluarga juga ikut andil iki diterapi gimana enaknya kasih terapi ini kan jelas ko buru-buru ngomong terapi wong keluarganya tidak ikut andil lagi ko ngomong nerapi, nerapiya gimana? Nyampe tak omongke kaya gitu se detail kaya gitu semianya Cuma 30\%. Nek saya berbicara angka opo yo $30 \%$ po bisa kan logikanya seperti itu $70 \%$ kan keluarga sama pasien itu. Disini kan Cuma sarana sebagai motivator penghubung wadah bukan penyembuhan jadi yang malah itu keluarga sendiri.

A : kalo misalnya ada yang lepas keluarga trus ada yang berhasil itu ada gak kang misalnya kaya disini?

B : ya ada antar 100 orang paling 1 orang mbuh-buhan nek logika

A : gak maksude yang udah pernah disini?

B : ya disini malah gak pernah, akhirnya malah lempar tangan lempar tangan bawa sana nanti kalo sudah akut pindah sana, lah itu apakah namanya penyelesaian namanya. Makanya kita ya enak-enak wae kita juga gak promo juga gak promosi buka iklan kalo dia mau silahkan trus keluarga yang tau masalahnya kita omongi keluarga masalahnya gini kalo gak mau ya udah kita juga gak maksa. Kalo sudah semampu kita kaya giniin trus keluarga tidak koopertif ya udah. Makannya tak bilang mentok-mentok cuman segitu ko pie, kalo kita bisa ketemu gusti Allah ki haaa ora iso ora iso wong kita satu wong aku gambare secara logis apa cara bahasane gak cuman di pondok sini, tak omongke semua rehabilitas cuman $30 \%$ kalo ada rehabilitas ada 
aku jamin bisa dibuktikan. Cuma sembuh sembuh menghilangkan halusinasi mbok anda itu bisa membuka plakat sendiri modal obat tidur, penenang sama vitamin. Obatnya Cuma tiga itu, penenang, obat tidur sama vitamin. Itu tiga hari saja sadar.

A : 3 hari tidur terus kang?

B : maksudnya malam mbuh opo ditidurkan lagi, siang aktivitas lagi. Tidur dua hari atau tiga hari sudah sadar total. Berarti blaho aja waras sudah waras nih, tapi gak tau seminggu dirumah ngebleng lagi. Apa itu kategorinya sembuh, smbuh kalo gitu, dengan cara lain dia dicapekkan dari pagi sampe sore dipaksa capek macul nanti kan sadar tidur kan capek tidur kaya gitu. Ya intinya kan melazimkan ya kalo malam istiraat kalo pagi untuk beraktivitas paling yang dbahas mungkin itu gak cuma mikir sampe gitu tok gak nyampe akalnya lah kan sing tak omongke dampak.e yo ra popo mung ngona ngono wae pie jangan mengeluh jangan trus akhire opo sudah disini aja di rumah nyusahin kan gitu. Trus tak paksain pa gak saya bisa katakan kaya tempat pembuangan kalo saya bisa mengatakan seperti itu. Ada yang sempet tak gituin dah kalo gitu gampang biar cepet gak nyusahin orang tua belikan baigon aja cepet selesai ya udah kan dari pada basa basi berikan baygon sudah tidak ada beban lagi secara kehidupan duniawinya. Nah kadang gak cuma sampean ada tesis S2.

A : hehe masalahe baca referensi mung ngono-ngono wae kang, lah ngene ko beda..

B : lah iya makane tak omongke mbok sing peneliti disini garis besarnya sama, karena sudah memikirkan dampak.e kui, cara mengatasinya gini-gini, akhirnya itu gak keotak-atik asal muasalnya itu. Nek semua terapi ke gangguan jiwa itu garis pokoknya sama, mau pak yai sudah memberikan terapi yang sudah bagus banget sudah manusia ke manusia itu tadi berarti cara menspesifikasikan lagi opo yo kalo dia seperti diri kita itu waras. Lah 
kita memandang diri kita bagaimana wong kita iso kerjo makane kita lebih yang kebawah lagi kebawah lagi yang paling dasar itu mana, makane carane dia andi di kamar mandi seperti kita aku bisa jamin dia bisa waras makane sampe dasarnya gitu to memanusiakan manusia itu seperti apa ya kaya gitugitu dulu jangan buru-buru mikir apa, nanti gambaran kita jadi sempit, kalo dari dasar itu kan bersambungan nanti kan normal otak kita juga akan normal, biar normal itu bagaimana kita mengarahkan ke tindakan positif, biar nanti kebentuk masalah yang dia alami tidak ngebleng itu gimana nah ituada otak atik itu itu pasti tidak lepas dari keluarga. Lah pengine di otak atik mbok sampe rambute ke wolak walik ora mungkin nek coro logikanya kan gitu. Ya pengalaman gitu menggunakan bahasa logika, logis karena anda anak sekolahan gak mungkin supranatural kan kita gak tau wong yang menyambungkan kan yang diatas tapi secara ikhtiarnya sebagai manusia ya seperti itu kan udah jelas dan kita sudah kepatok dengan ikhtiar itu dengan diluar keluarga cuman 30\%. Anda sudah sekuat tenaga sudah begitu baik kan begitu sudah bagus ko mentek lagi lah kemampuannya cuman segitu ngono loh yang $70 \%$ itu siapa ya keluarga sama pasien. Ya jangan salahkan rehabilitas setengah tahun sudah sembuh ko kambung lagi, tiga bulan bawa pulang ko kambuh lagi jangan salahkan kalo keluarga tidak berubah koopertif keluarga, lah ngono loh. Ya itu yang jadi kuncinya disitu, jadi kan mikirnya sana wah sudah sembuh kasih apa kan pulang ngebleng lagi pindah sana sembuh kesek-kesek sembuh kan yang dicari apa gitu kan yang dicari nek koyo ngono aku iso sulap-sulapan. Tak kasih sulap-sulapan gampang banget dan itu kan karena anda sekolah oh dosennya oh udah bagus dengan cara ini acc, tapi kalo anda secara riil ya kaya tadi.

A : kalo keluarganya mendukung kang, kan otomatis anaknya disini ditearpi, dari keluarga mendukung dari sini mendukung itu hasil akhirnya itu?

B : bagus.

A : bagusnya tetep disini apa dibawa pulang. 
B : orang yang sudah sadar dia tidak ngebleng lagi semuanya manusiawi pasti pengen pulang pengen kerja cari duit kya gitu, itu manusiawi sekali. Jarang, sampean ngene ki koe neng pondok wae, wah aku bar rampung kuliah aku arep kerjo itu manusiawi sekali jangan berfikiran, disini kalo gak mau gak papa dia keluar pengen cari kerja ko ditahan-tahan. Lah gitu loh itu umum sekali. Dari yang ngebleng total itu dia pengen pulang pengen kerja nah itu. Makanya keluarga kalo mau mendukung itu modus apa benar. Wah paling kalo gak diterima paling bisa ngaji nah repot lagi. Saya sering ngalamin kaya gitu makane aku nerangke sampean bayangane keluarga mendukung secara original apa tidak, tak bilang sudah bosen itu tadi. Satu durasinya sudah bertahun-tahun sampe 5 tahun. Jarang yang ngebleng setengah bulan bawa kesini, tapi rata-rata rasa sakit dulu nanti tiga bulan kambuh opnamke lagi pindah tempat pindah tempat nah repot dia sudah kena obat psikotropika yang serba obat sarafnya juga kena akut, gemeter gini jadi masalah baru lagi kita memulihkan fisiknya apakah bisa instan? Kan lama, lah makanya dobel-dobel lah anda kaya gitu tadi sedangkan dia kalo tidak kasih obat sedangkan sudah pake obat gak tidur. Makanya ini kunci tak kasih gambaran bagaimana cara nerapi model anak-anak asal muasal karena manja karena over atau bisa dikatakan kasih orang tua yang over akhrinya menjadikan anak manja trus terapinya apa, buatlah PAUD untuk anak yang seperti itu, seperti anak PAUD kan bermain diarahkan modelnya kaya gitu setiap kegiatan yang happy mbok kasih kegiatan apa yang gak lazimnya orang itu, yo karena menurut dia iseng-iseng kalo sudah jenuh gak mau gitu to, lah susahnya disitu, kalo dia pekerja yang tidak anak manja cepet kasih kegiatan capek tidur dan membuat aktivitas kegiatan yang bangun malam capek aktivitas istirahat itu lebih gampang kalo yang susahnya itu loh kadang tadi dia gak mau kerja, tak kasih yag simpel wae nyapu nyuci bajunya sendiri itu aja ndak bisa ko iya pa ndak,nek coro logikane sampean ki kepie, kerja opo kerja bengkel ayo tak ajak ke bengkel kalo gak pas mesti di pecat gak beres, Cuma pernah masuk di bengkel sana, dimasukan 
mungkin karena dimasukan kalo kerjanya ngungkuli mandor ya di pecat sampai dasarnya lagi, saya mikirnya hal yang riil, jadi kelihatan anak manja apa dia anak yang tidak manja, sifatnya anak manja itu apa kalo keyakinan harus, kalo salah gak mau disalahkan trus apa namnya gak mau diatur lah bahasanya. Akhirnya apa yaitu ngotak ngatiknya gimana ngatasi wong manja itu, padahal orang manja tidak menyerang koyo ngono kui orang biasa wae di serang pemalas. Ya kita aja kalo ngaji malas, semuanya lah kalo over malesnya kan bisa ngebleng jadinya. Lah itu yang terjadi saat ini kang, lah anda mencari sing gila-gila original sekarang sudah gak ada. Ya itu anda belum menemuin gangguan jiwa bukan karena anak manja bukan karena secara psikis tetapi secara penyakit, ada!

A : contohnya apa kang?

B : orang yang terkena epilepsy atau ayan.

A : ayan, ooo.

B : itu otaknya udah ngebleng. Jadi kalo orang ayan itu kan secara logikanya gini waktu dia ambuk dia kan kejang-kejang gini otak dia kan gak sadar nanti saat dia sadar kadang dia mukul orang kadang dia gak inget trus kehidupannya sekarang ketawa sendiri, haa. Aku pernah ngalami kaya gitu, apakah itu termasuk secara psikis kan secara penyakit penyakit apa namanya secara medis to, lah ngatasinnya gimana kalo koyo ngono kui padahal keluarganya gak fer-feran gak tau wah ini ayan.

A : trus gimana kang?

B : ya disuruh bawa pulang, dari pada disini pernah dikamar temene dihajar buk buk buk dia tidak ngerasa mukul tidak merasa bersalah ya kaya gitu kalo orang ayan itu, dia itu gak berani kalo saat ngobol sadar jadi ya repot, itu baru mikir penyakitnya loh belum mikir karakternya dari kecil kaya gimana loh apakah manja atau bekerja ya saya repot lagi satu mikir kita itu tau penyakitnya trus tau dulu karakter anaknya itu gimana. Kadang tadi loh 
apakah dia manja atau tidak ya gitu loh kalau anda pengen menerapi itu harus tahu dulu, kalo sudah manja ya sudah, berat. Padahal kuncinya bisa menerapi kalau dia tidak manja. Kunci yang paling untuk memudahkan terapi disitu.

A : kalo kira-kira manja itu berapa lama kang terapinya disini yang manja itu kalo misal dari keluarga mendukung itu loh?

B : rata-rata keluarga gak ndukung ko' trus pie hehehe, nek ngene kan angel anda mbahas secara teoritis lah sini bahasnya secara riil tidak mendukung. Yang dibawa sini sudah akut semua trus pie, bawa sana sana sana. Ya sudah tak bilang tadi sudah kehabisan materi buka google oh tanya sini sana Al Qodir sama materi tidak dipentingkan kan gitu, ada wadah bahkan tidak keganggu lagi, trus gimana kalo bahas kaya gitu, nyampe keluarga tak telpon tak terangin kaya gini kadang yo mung acuh makane saya berani ngomong kasih baygon wae saya bisa ngomong gitu. Sampe setahun dua tahun, pengennya keluarga ya itu dia tidak pemalas, rajin, biar pinter ngaji ya keluarga pengen gitu semua, jadi kaya menaroh breg gitu, makannya kalau bahasnya sama peneliti disini tak putus dulu omongane anda mikirnya ada yang kooperatif, sini mikirnya hal yang riil itu gimana cara ngatasinnya ya percuma aku ngomong sama keluargane gak nyambung, makane saya kalo sulap-sulapan juga bisa itu halusinasinya jadi sadar udah gak nyampe sebulan ndak ada seminggu kalo cuman menghilangkan halusinasi punya dee loh oh sudah sadar ini udah to bawa pulang sana wae, makane dia datang ke sini bukan karena kita, datang minta tolong oke tak jlentrehke apa adanya kalo dia mau keluarga yo bersama-sama si anak berubah keluarga juga berubah itu ngomong opo enenge wong kita cuman penengah ya nyatanya waktu ngomong hanya ya ya ya kita kan ngomongnya secara riil. Ya susahnya disitu, trus anda mau meneliti terapinya gimana secara spesifiknya gimana tak omongke dulu, tau masa terapinya sama kaya orang lain saya makan dia makan saya mandi dia mandi lah bahasanya mung koyo ngono 
kui nek secoro, bayangane anda terapine secara sing khusus ki di adusi banyu kembang po ini pake di strum kan ngono, makane anda perlu di cuci otak.e juga mungkin anda mikir ra rampung-rampung skripsine ki akhire iso ngebleng ra iso turu, anda itu rasane orang kita itu bisa melihat rasane halusinasi ra sah pake amalan ra sah pake yang lain, udah tidak tidur tiga hari wae mau ngopi ngrokok silahkan nanti nek anda akan merasakan apa halusinasi itu. Hari pertama ya awake panas, hari kedua kalau jalan sudah benteor kadang-kadang kaya ngombak-ngombak, hari ketiga sudah mulai kaya bayangan lewat kadang ada suara itu loh itu dalam keadaan kita sadar loh, lah sedangkan kaya gitu udah bertahun-tahunan dah bulan-bulanan, kejadian itu mau subuh, mau subuh ngantuk tidur baru bangun siang nanti setelah itu terus sampe sebelum subuh baru tidur lagi. Jadi selama halusinasinya orang itu biar bisa tidur dia malah bingung berfikir timbul halusinasi itu lah kita memulihkan hal yang lazim ya turune iki seumume diri kita, lah carane kepie? yo okeh dalane iki, nek coro ngene pusing yo coro kegiatan, kadang kegiatan wae, yo kita tahu apa tidak karakter kegiatan itu terpaksa ndak, yo akibat karena dia itu manja gitu loh, yo kita bahas kegiatan harus imbang dengan karakter pengaruh sifate, itu belum nyampe keluarganya loh baru nyampe terapinya untuk si pasien itu sendiri belum masalah yang bikin dia meletus itu belum di otak atik belum masalah fisiknya juga. Sampean njupuk tarbiyah ngambil jurusan apa?
A : manajemen pedidikan. Judul skripsi kang?
B : heeh
A : manajemen pendidikan pondok pesantren dalam menangani santri skizofrenia (gangguan jiwa).
B : manajemen iku secara opo, secara? 
A : secara umum. Jadi kan kalo manajemen kaya perencanaan, pengorganisasiannya apa kegiatannya apa ah trus strukturnya, kaya pengawasan kaya dari segi njenengan itu bagaimana.

B : yo kui nek koyo sing nggon sekolahan. Manajemennya kan dia masuk kesini tidak dianggap gila, jadi kegiatannya sampean itu apa, yaitu waktunya ngaji ngaji waktunya sholat sholat, kegiatan yang diluar itu apa yang bisanya santri itu yang suka bangunan bangunan yang suka masak ya ke dapur ya kaya itu tadi, manajemennya ya itu tadi. Ya sukanya opo sukanya dapur ya dapur bawa kayu opo bawain masakin sayuran, pengawasannya sini ya kaya bapak angkat kaya orang tua, hubungannya anak dengan orang tau itu gimana ya itu harus ada seperti orang tua, kalo kita mempunyai makane ki tak bilangin kita punya sikap kaya momong anak kecil persis seperti itu jadi opo kasih sayang. Anak kecil itu gimana, waktu dikala itu kita harus tegas dikala itu kita harus merangkul nah itu kan salah satunya gitu, kaya kaya gitu tadi pengawasannya kita iut harus momong anak kecil. Jadi gak bisa digambarkan kaya secara kaya manajemen belum tentu si A ini sama dengan si B wong ngomong cuman saya sendiri. Coba sing tak omongin wong rolas (12) tentang manajemen koyo ngene-ngene. Tak kasih gambaran nek ngomong anak 12 karakter kan genah tahu, ahirnya 12 orang karakternya bedo kabeh arep manajamen gimana secara teoritisnya, makane tak kasih gambaran tadi momongnya itu seperti anak kecil dimana yang satu itu harus di tegasin oh ini butuh pendekatan opo kasih sayang yang lebih kesed nah itulah peran orang tua. Makane saya katakan disini saya sebagai santri kenapa saya ngomong karena berhadapan dengan orang lain sebelum melangkah kan kaya tadi ketemu keluarga tak kasih bla bla gini belum saya nanti saya kecil lah kaya gitu, ya sampe baju yang nyuci saya sendiri

A : oh ini? 
B : ya sing arep nyuci siapa tak omongke mau. Iki nyuci tak ajari nyuci orang banyak orang 5 ngajari nyuci ki pernah tak kasih ember 4, bajumu ki loro eh telu katok kaos sarung, dieling-eling sing di enggo iki cemplungke ember kene di kum sek sing kae podo di eling-eling ki tak tungguni nyuci set set wes nek wes di jemur tak kasih au tempate wong dia tau yang naroh dia sendiri dieling-eling bajumu sing iki, ngko nek wes garing ke.ne aku neng kamar. Gak jalan! Ya aku makane manut opo berani ko boro-boro wong mandinya aja gak bener. Dari pada saya kehabisan barang di pakai abis saya juga gak ngurusi ngono doang saya juga ngurusin ya nyopir, kadang, ndak cuman mikir ini aja ngono loh. Makane ya itu tak gae sistem tak roling. Oke tak cuciin kabeh, yang penting waktunya mandi mandi waktunya sholat sholat, trus kesukaannya apa, kalo mandiin waktu itu kalo yari orang 7 itu udah makan berapa jam, caranya gimana makanya gimana caranya dia bisa ngumpul ke saya biar saya gak usah nyari, tak ritme kamu sukanya ngopi ngrokok, nyetok di kamar neng lemari, rokok kopi snack dan mie pagi dan sore tak kasih nah pagi dan sore dia kan nyariin saya, kang minta roti tinggal di kasih, butuh timeing juga butuh waktu ya membiasan itu terapinya makane saya bilang knapa karena latar belakangnya 90\% karena anak manja, tak suruh nyapu sebentar aja sudah hilang orangnya. Kaya gitu to repotnya disitu.

A : itu tak lihat banyak yang dewasa kang?

B : ya rata-rata mulai lulus SMA bleng.

A : oh berarti setelah SMA ya kang.

B : heeh sudah mulai kaya menginjak masa dewasa. Lah nek akan kecil sudah ngebleng ki pikirane mengendi, wong lagi hobi-hobinya. Makannya tak bilang tadi faktor dia ngebleng karena anak manja 


\section{HASIL WAWANCARA III}

Wawancara dengan Sekretaris Pondok Pesantren Al Qodir sekaligus Mantan Pecandu Narkoba

Narasumber : : Prhady Hastary

Tanggal wawancara : 9 Mei 2017

Pukul : $13.30 \mathrm{WIB}$
A : Penulis
B : Sekretaris Pondok Pesantren Al Qodir
C : Bendahara Pondok Pesantren Al Qodir

A : Nek kurikulum pondok ki sing gawe sopo mas?

B : kan kalo kurikulum pondok kan ada Diniyah kan mas jadi semuanya ya trus habis maghrib khataman Qur' an, trus subuh sama ba'da isya ngaji sama pak Kyai.

C : tenane? Tolong di kroscek yo mas, mending sampean nginep neng kene 2 hari atau tiga hari kan keto kabeh.

A : aku bien pernah neng kene selama 4 hari diklat organisasi internal kampus.

A : lah nek sing gangguan jiwa ki yo tetap ngaji meng abah po pie? Koyo meng kang Ibin.

B : yo santri gangguan jiwa tetap ngaji, ba'da maghrib tetep meng Abah. tapi kalo bisa yo sorogan sama pak Kyai walau baca bismillah rampung salam gitu kan ada juga yang baca terus sampai yang sampingnya gak kebagian itu ada terutama santri yang baru gangguan jiwa.

A : nek aturan pondok ki tertulis opo aturan lisan mas? Misale aturan sing nggo anak sekolah aturan sing nggo anak khusus mondok tok. Kan tak tangled kang Ibin kalih pak Kyai kan beda, 
B : mmmmm ada yang tertulis ada yang gak, jadi kalo rapat-rapat saja dirapatkan, tapi anak pondok sama anak itu beda. Kalo yang tertulis lebih ke tata tertib. Ada sih 13 tata tertib contone tata tertib bawa handpone contone.

A : sing gak entuk gowo HP ki SMA kebawah?

B : SMA kebawah.

A : bang, treatmen yang dilakukan setiap hari dulu pas sampean masih awalawal disini?

B : treatmennya paling ya dzikir malam, sholat. Tapi yang betul kata bapak timbul kesadaran diri untuk stop tidak make, seperti itu.

A : kang, selama di pesantren aktivitas apa yang dilakukan sampean pas dulu terkena narkoba selain beribadah?

B : yang mungkin sebisa saya gitu ya, saya bantu-bantu di dapar yah, nyapu bersih-bersih yah yang bisa saya lakukan apa yang menurut saya baik. Sedangkan yang di treatmen dengan alam mungkin lebih menyatu dengan alam ya, mungkin kegiatan sawah menatap keindahan alam ya, mungkin gitu aja. Yo ngadain kegiatan atau apa diajak. Supaya ga terlalu dinikmati rasa takut, perasaan halusinasi itu kan. Tapi kan kalau Kang Ibin punya latar belakang kaya itu juga kan. Orang lagi kek gini dan pengalaman dia selama ngurusin orang kek gini kan. Ga bisa diapain. Dia pun tau toh. misal, perlu dicapekin orang ini atau misal perlu kerja keras. Tapi satu sisi jangan dilihatin atau apa. Tapi disuruh dulu ini kek gini, kek gini. Jangan misalnya ngomong terlalu tinggi atau keras nadanya. Terkejut atau apa. Gampang mutung kitanya. Bisa gampang mutung, bisa gampang down. Dia tu cuma punya dua pilihan narkoba itu. Bisa ditegur dia itu marah, mutung. Bisa juga dia drop. Contohnya aku keluar mau nganter makanan. Aku keluar, kambuh, posisi jeglek otak aku. jeglek otak aku kambuh kan. Nah aku nganter aja. Nganter ini kan. Orang rame pinggir jalan tuh. Waduh gimana ya aku pulang 
ke pondok rame banget. Wah di depan aku ga bisa gini toh. Abah keluar. Ga tau mungkin yo ikatan pasien ada perhatian khusus yo. Dulu awal-awal yo. Walaupun pasien diperhatikan semua yo. Jadi Abah keluar. Mungkin maksudnya supaya anak-anak itukan biasanya kalau liat Abah kan pada nyingkir semua kan. Anak-anak pada masuk semua, langsung sepi. Langsung ku tengok, Alhamdulillah langsung jalan aku. langsung munggah ke kamar. Awal-awal dulu kek gitu. Ketika apa yang kurasain menurutku benar, nurutku benar tapi orang itu menghambat gitukan. Emosi naik. Langsung naik biasanya. Misalnya kaya dulu itu naik yang aku nganter nasi aja. Itu sepele lo. Aku pikir ini untuk kepentingan pondok, kok ga ada yang mau nemenin aku. Aku marah yo saat itu. Asu kabeh. Itu keluar. Hahah. Kata-kata dari kotak sampah keluar. Yo aku ngomong kek gitukan sangking emosinya. Kurang ajarnya ngancani sampe ga mau. Masa aku ngusung ini sendiri. Ga bisa aku ki. Ada satu orang ku ajak ga mau. "Asem iki," kata ku kan. Emosi memuncak, jeglek. Bawa motor, sudah ada yang nemenin. Motor aga sebegini sedikit, aga sandung sedikit lah, langsung jeglek aku. aduh kambuh iki aku. Liat orang di depan banyak aduh kambuh aku. Pas kambuh, halusinasi, paranoid atau apa. Kena aku. Aku dulu itu kek gini lho. Latar belakang parno aku timbul. Ini mungkin karena aku masih menjadi pemakai kuat, fasilitas ku dicabut mungkin. Mungkin bisa seperti itu. Ketika liat orang rame, gitukan. Misalnya orang rame duduk-duduk pinggir jalan, gitukan. Satu komunitas kelompok gitukan. Orang yang ga kenal sama ku ga masalah. Tapi ini kenal. Ini kenal dan ketika di depan mereka itu, kewo, sungkan atau gimana. Perkewo. Duh, orang rame ki mundur aja. Mutermuter lewat mana itu kan. Bedanya kasus aku ki kan, aku makek, mukaku pucet, putih, mata mendelok gini gitu kan nah. Lewat di depan orang kenal. “kira-kira aku ki ketahuan ga ya."sebisa-bisanya matanya diginiin, gitukan. Ini dilap, biar ga putih gitu kan. Nutup-nutupin gitu ini kan. Karena kita nutup-nutupin itu jadinya kan, satu timbul paranoid kan takut ketahuan. Mungkin awal-awalnya tahap itu terbawa kek gitu. Jadi paranoid juga. 
A : sudah kambuh berapa kali kang dari awal disini sampai sembuh?

B : Lupa. Lupa. Aku tu kebanyakan tu lupa sebagai pasien. Maksdunya tu nerima. Aku tu nerima saat-saat kambuh atau apa. Kalau aku tu pasien. Kondisinya kan aku ga makek lagi atau apa. Kambuh tu maunya yang wajarwajar aja. Yang penting bukan kambuh makek atau apa. Pikiran aku tu kek gitu. Jadi aku berusaha untuk sedikit lebih tenang. Karena kemarin itu aku ada sedikit perlawanan. Perlawanan dalam diriku kok kambuh aku kok kek gini. Aku nerimo menurutku ya kalau aku ini kambuh. Setiap aku kambuh kalau lagi pusing pulang aja. Kalau lagi pusing itu. Makin ga ngaji makin ga apa. Aku lagi pusing. Mohon pengertian aja. Kira-kira itu. Tapi kita ga bisa toh kalau lagi pusing ayo keluar aja. Di sini secara tidak langsung diajari mental. Contohnya kaya aku belanja ke mana. Walau lagi kambuh tangan gemeteran tetep tak adepin. Salah satunya mungkin di saat orang rame atau apa, di depan orang pembesar, biasanya di belakang panggung. Ini kok tiba-tiba didudukin. Oh setelah dipikir-pikir fungsinya ini untuk ini. udah ketemu orang yang lagi kek gini-kek gini, tujuan bukan untuk itu, untuk diriku. Podo kata-kata aku butuh otakku yang waras. Supaya aku bermanfaat buat ini. kalau aku kek gini ga bermanfaat. Ga bermanfaat itu buat aku butuh pengorbanan buat jadi yang bermanfaat itu. Aku pernah satu minggu-dua minggu di sini kan. Makan-tidur. Timbul pemikiran kok aku kek gini. Makan-tidur makan-tidur. Mungkin pola hidupnya dulukan udah ga kerja atau apa. Aku kok kek gini. Keknya jadi orang yang ga berguna. Padahal kondisi saat itu ya kalau bisa pekerjaan itu ya yang simple-simple wae. Lagi proses kestabilan. Berapa seringnya aku ga tau lupa. Tapi biasanya, pas kapan-kapan itu, pasti ono suatu benturan lah. Berbenturan. Pernah aku ngeblank suatu kali. Ngeblank-ngebalnk itu berapa kali ya. Mungkin kek kambuh. Ribut sama teman. Nahan emosi yang berlebihan sampe badan dredek-dredek semua. Itu masih timbul ngeblank atau apa. Suntuk mungkin untuk orang luar itu sering orang-orang luar itu mungkin. Seringkan. 
A : rencana disini mau berapa lama lagi kang, kan sudah lama to. Apa cari pendamping juga? Hehehhe

B : ahh mungkin kalo secara fisik udah ya baik lah, tapi kalo secara ee kembali ke lingkungan butuh bekal agama gitu yah. Ya

A : Oke kang, sekarang tak tanya sarana kang, kalo kamar tidur dan kamar mandi disini ada berapa kang?

B : $12131415161718,2021222324252626.2727$ tambah 8 berapa mas?

A $\quad: 27$ tambah? 35

B $\quad: 35$, pondok putri ada 5 bearti lima sama pondok putri.

A : nggo BAB II tapi kurang, waahhh isi data iki

B : tapi banyak ini kan skripsi orang kan bab II.ne kan podo.

A : wes tak delo gx enek mas.

B : ooh berarti gx ono o.

A : karena kalo beda fakultas atau beda jurusan kan beda BAB IInya beda dikit.

A : nek kamar mandi piro?

B : $\mathrm{mmm}$

A : kamar mandi?

B : kamar mandi? Berapa jumlahnya?

A : hooh

B : : 123456789101112131415161718 . Depalan belas

A : delapan belas. 
B : itu untuk putra.

A : putra!!! Hehe

C : apane mas? kamar mandi karo kamar tidure akeh kamar mandine. Hehe

B : itung lagi mas. Lantai 2 ada 4 mas, di lantai 1 ada 12345678910,1 2345678 . Berapa mas?

A $: 18$ mas?

B : hmm 18 tambhan atas ya. Itu ditambah 10 .

A : kan yang atas 4 bawah 10 tambah 8.22 berarti.

B : kamar mandine ada 22 mas. Itu yang putra ya mas, kalo putri saya gx tahu. Mas masuk kamar mandi, lah iyo to masa masuk ke sana. Dikira-kira aja mas. Trus yang di depan sana ada kamar mandi juga,

A : sini..

B : bukan, itu sebelah sana yang deket sama kolam. Itu kamar mandi umum ya yang deket sama kandang kambing.

C : kamar mandinya kambing.

B : kamar mandinya kambing aja baik banget. Lah itu sanding motor loh. Ada 8 , itu deket tempat wudu mas. Itu yang kaya tat surya opo sih mas

C : tata surya opo to?

B : ini pembangkit tata surya,

C : ooh yaya

S : pak ady?

B : dalem febrian.

B : mongo mba, digolek.i loh mba 

A : nek gax salah kang Ady dadi sekteratis. Lah sampean dadi apa?
C : dadi wong. Hehehe
A : iki opo jabatane?
C : q ki ra duwe jabatan. Aku ki koncone bang Adi.
B : konco bercanaan saya. Hahaha
C : iki loh mba saldone. Ini ya
S : ko okeh tenan e.
C : loh ko okeh tenan saldone
B : iki bendahara yayasan mas.
A : ooh
P : : saya ya administrasi, nek kerjaane diidialke.
A : pantesan kerjane sering bareng.
C : duet maut mas, hehe
B : sering bareng mergo sampean ngertine neng kene, hehe
C : nemarik kesimpulan berdasarkan pengalaman
A : karena sering bareng, hehe
C : iki mbusek gambare pie, ko ra iso e

A : nek data-data koyo lembaga pendidikane kin due ra mas?diniyahan trus TK trus.

B : tiap ini beda. Itu ada yang ngurusi sendiri mas kalo yang diniyah
A : mm materine ya disana?
B : iya 

A : sama siapa mas?
B : sama pak Toriq.

A : kalo biasanya kan pertahun kana ada program mas, kan biasane kaya pengurus punya program apa itu? Punya data-datanya gx mas. Kan kalo yang di akhir akhirussanah. Kalo yang lainnya itu ada lagi gak

B : lainnya itu... kalo itu agenda tahunan. Bentar lagi mas, kalo bisa datang ya datang. Tanggal 20 penceramahnya dari PBNU dari Jakarta.
A : : tgl 20 sesuk kang?
B : heem. 20 mei, ehem
C : kalo namanya bapak sopo namane.

A : emang akhirussanah ki menjelang puasa po pie mas? Rutinane.

B : mmmm ki filosofine dowo banget

C : sampean gek bien akhirussanahe bulane opo mas?

A : nek nggonku tergantung iki sih mas. Dadi q kan MAN kan.

C : ohh dadi melu aturan lulusan

A : iya, dadi ngepasi pas lulusan 


\section{HASIL WAWANCARA IV}

Wawancara Ketua Madrasah Diniyah Pondok Pesantren Al Qodir

Narasumber $\quad$ : M Thoriq Aufar

Tanggal wawancara $\quad$ : 9 Mei 2017

Pukul : $\quad: 16.30 \mathrm{WIB}$
A : Penulis
B : Ketua Madrasah Diniyah
A : biasanae nek madin iku pinten kelas mas?
B : sekawan.

A : kelas setunggal ngengge nopo mawon.

B : tingkatane sami, bedanipun kemampuan.
A $\quad$ : sami
B : nggih

A : nek sing gangguan jiwa niku melebet mboten?

B : mboten.

A : oh gangguan jiwa berarti. Berarti sing nopo sing ngaji sing wong sing wong biasa.

B : nek sing sekolah. Nek sing sekolah teng mriki mboten ngaji nggih angsal.
A : nek mboten sekolah niku ngajine pripun kang.
B : nek mboten sekolah nggih ngajine langsung, sorogan niko. Onten sing subuh onten sing
A $\quad$ : nek sing madin kpn?
B : nek ba'da asyar namung ngaji. 
A : biasane sing Madin niku SMP nopo SMA?

B : ngggih campur, SMP SMA. Onten sing... werna werni onten setunggal. SD

A : Nek sing kuliahan onten kang?

B : mboten. Eh onten sing S2 nggih onten, sing ngajar ngaji nggih onten.

A : kulo kan ningali mba-mba kalih mas teng kantor niku kuliah.

B : nek madin kan mboten dibagi berdasarkan umur, dibagi berdasarkan kemampuan.

A : biasane masuk kelas utama, kriterianya apa?

B : nek kemaren tes. Tes kemaren baru baca. Pada sama apalan terus kalo tahun ini itu ada yang naik itu ada yang turun ada yang tetep.

A : nek madin kitab kuning opo,?

B : :kalo baca Al Quran pegon juga. Kalo mata pelajaraanya baca qur'an tajwid serta yang pegon nanti pelajaran Imlaq. Tentang bab Sholat, itu berapa yang masih.

A : biasane nek madin enek opo ilmu alat niku kang.

B : ada tapi itu masuk kelas 4. Awalnya to nanti masuk kelas 1 Tsanawi.

A : berarti kelas 123 belum ya kang. Dulu aku diniyah kan gak kelas temenku 3 kelas kan menurut SMA jadi yang SMP ya ngikut. Yang kelas pertama jurmiyah, yang 23 imriti. Kalo Alfiyah gak pada nyampe gak pada kuat.

B : kalo yang kelas 5 itu belum ke isi, baru sampe kelas 3. Sesuai standar kurikulumnya aja. Kalo kenaikan kami tidak memaksakan kalo diniyah. Ya kalo semuanya kelas 1 ya kelas 1 .

A : Kang Ibin? 
B : bukan. Kang Ifa'i.

A : turene kang Ibin arep nikah.

B : nggih

A : oh sing ngganti ki sopo.

B : berarati sampean sing....

A : heeh. Yo orang sing pasiene sing mas, dadi ki neng pengasuhane. Dadi pak Kyai ro kang Ibin. tak kiro kan kene yo terlibat makane rene juga.

A : sampean skripsi kang.

B : iyo. Sampean asline ndi kang?

A : Cilacap.

B : bien kuliah ndaftare ketompo UIN KI. Lah kui malah neng UNY ketompo neng jurusan Bahasa.

A : Aku bien njukuk opo Pendidikan Sosiologi ro Geografi gak ketrimo. Malah sing tes sing UIN malah ketrimo y owes. Bien PAI tapi pilihan ke 2, MPI pilihan pertama. Biasane wong kuliah kan dadi guru.

B : biasane nggo pengkaderan.

A : oh PMII, oh q gx aq melu kang kwatir idiologine mbok, masalahe neng kono terlalu iki banget. Kan saiki di pegang dewe. Dadi saiki arang demo, tiap dino geger.

B : ono KMNU.

A : q mung awal-awale wae, lagi di gawe. Peresmian. Nek sampean melu neng UNY KMNUne.

B : mau sampean mlaku?

A : ora. 
B : oh mbok sampean mlaku motore tinggal pondok.

A : biasane sing diniyah ki cuma cah pondok opo ono sing kalong.

B : ono sing kalong.

A : biasane sing tetap sing lewih okeh.

B : ora. Sing pondok sing lewih okeh. Yo koyo sekolahe. Nek sekolahe SMA yo neng pondok kae, neng cedak pondok putri.

A : oh neng nduwur masjid.

B : ono neng kulon 2 kelas neng lor 2 kelas neng lantai 2 kabeh.

A $\quad$ : ruang guru neng latai 2.

B : TK ro SD neng kidul. Neng lapangan ono gapuro neng mburi dalan. Tapi nek lewat ngarep yo gapuro sik lurus enek pertigaan kanan.

A : dadi TK-ma MI ono yo.

B : tapi rung lengkap, sing MI sampe kelas 4, sing SMA lagi kelas 1. Sing SMP sampe kelas 2.

A : awale sempet kapan pas dzuhuran rame neng jero. Malah gede pondoke

B : sekolah mau lumayan okeh mulai sekoah rame kalongan.

B : sampean mbien neng ndi?

A : neng Cilacap, tapi sebelah kulon neng Majenang neng Cigaru kan neng kono ono MANe juga, dadi neng kene enek pondok neng sebelahe sekolahe.

B : tapi sekolahe nggone pondok juga.

A :dudu. Maune niki melu pondok trus dadi MAN trus misah pindah dadi adoh sitik. Trus ponodk.e nggawe MA dewe. Pas awal-awal malah iki ujiane neng MA ndompleng, kan dibawah piro kan gak entuk ujian makane ndompleng. 

A : nek sampean neng ndi?
B : neng Kediri.
A : mondok juga?
B : neng ploso.

A : nek neng Kediri gede ndi mas karo Lirboyo?

B : yo gede lirboyo mas, ploso lagi generasi k-2 mas. Lirboyo pondok tuo.

A : mbien koncoku enek pindah soko ploso mbien cah mbadung pindah ke mas. Namane cah mbadung yo terap mbadung pindah ke MAN.

A : nek sing soko lirboyo penyebaran santri sing wis

B : model koyo nggone dewe PPL.

A : yo

B : kilatan.

A : traweh yo ngisi fiqih, biasane koyo KKN lah, jadi sedesa mung 2.

B : dadi model koyo Tegalrejo. Tegarejo yo model.e koyo ngono yo Wonogiri Wonosasi Gunungkidul.

A : lah saiki gak enek meneh,

B : sampean asli Cilacap?

A : nggih, kulo wes rodo ngulon e mas, kecamatan kulo kan perbatesan kalih jawa barat, Cipari trus Majenang kui kan wes perbatesan kabeh ,makane kan sing daerah Majenang kan separo sunda. Yo kasar, hehe jawane kasar sundane kasar.

B : tapi adat.e adat jawa apa sunda? 
A : neng konone. yo jawa mas. Tetep jawa nek sunda mung biasane neng daerah gunung.

B : nek Cirebon daerah sunda malah bahasane jawa ya.

A : heeh mergo enek wali paling.

B : neng ngone aku neng perbatesane yo jowo mas, sedesa kakange sing mabahku yo neng kene, oh sih jowo to.

B : bedo-bedo.

A : tapi apike yo iso 2 bahasane

B : kulono 2.

A : nek sing perbatesan malah iso jawane yo iso sundane tur alus. Nek q gx iso sunda.

B : nggih

A : nek mbelek.e ora iso.

B : dadi nek burjo roto-roto dodol.

A : ciri khas.e 


\section{Catatan Lapangan}

1. Santri gangguan jiwa dan narkoba yang masih dalam tahap penyembuhan di pesantren Al Qodir saat ini ada 4 santri.

2. Menghilangkan efek santri pecandu narkoba yang sudah akut butuh waktu 2 tahun untuk menghilangkan paranoid atau halusinasi. Sedangkan untuk mempersiapkan hidup di masyarakat butuh waktu 3 tahun yaitu baik berupa bekal agama maupun skill yang ditbutuhkan untuk menunjang kehidupan sehari-hari. Jadi santri pecandu narkoba bisa dikatakan sembuh total selama 5 tahun.

3. Sedangkan peraturan pesantren Al Qodir yaitu tidak boleh bawa HP bagi santri SD-SMA, pulang minimal satu bulan satu kali dan harus izin ke pengasuh pesantren Al Qodir, keluar pondok harus izin, tidur tidak boleh lebih dari jam 11 malam, piket sesuai dengan jadwal piket yang ada.

4. Kegiatan belajar mengajar bandongan dilaksanakan setiap ba'da sholat maghrib, kitab yang diajarkan Tafsir Jalalain yang langsung dibacakan oleh KH. Masrur Ahmad, sedangkan ba'da subuh, isya dan dzuhur sorogan hafalan Al Qur'an bagi santri biasa dan ba'da isya sorogan bagi santri gangguan jiwa dan narkoba. Kitab yang di sorog oleh santri gangguan jiwa dan santri pecandu narkoba yaitu Iqra', Jus Amma, Al Qur'an serta kitab dasar sesuai dengan kemampuannya. Kegiatan madrasah diniyah dilaksanakan pada hari senin, selasa, rabu dan sabtu setelah sholat asyar. Sedangkan untuk biasa operasional belajar mengajar, santri dikenakan biaya Rp. 10.000 per bulan. Sedangkan kegiatan mingguan yaitu pada malam jum'at setelah sholat isya diadakan mujahadah di masjid Al Qodir yang diikuti oleh semua santri. Sedangkan kegiatan bulanan diadakan pengajian umum dari PCNU Cangkringan dan siang hari diisi semaan Al Qur'an oleh santri Al Qodir dan di akhir pembelajaran diadakan akhirussanah yaitu kegiatan tahunan pesantren $\mathrm{Al}$ Qodir dalam rangka penutupan proses pembelajaran selama satu tahun. 


\section{KARTU BIMBINGAN SKRIPSI}

1. Nama Mahasiswa : Arif Musafa

2. NIM

: 13490032

3. Pembimbing

: Dra. Wiji Hidayati, M.Ag

4. Mulai Bimbingan

: 19 Januari 2017

5. Judul Skripsi

: Manajemen Pendidikan Pondok Pesantren Al Qodir Cangkringan Sleman Yogyakarta Dalam Mengasuh Santri

6. Fakultas

Gangguan Jiwa

7. Program Studi

: Ilmu Tarbiyah dan Keguruan

: Manajemen Pendidikan Islam

\begin{tabular}{|c|l|c|l|l|}
\hline No & \multicolumn{1}{|c|}{ Tanggal } & $\begin{array}{c}\text { Bimbingan } \\
\text { ke }\end{array}$ & \multicolumn{1}{|c|}{ Materi Bimbingan } & Tanda Tangan \\
\hline 1 & 25 Januari 2017 & I & Penyusunan Proposal \\
\hline 2 & 8 Februari 2017 & II & Bimbingan Proposal \\
\hline 3 & 22 Februari 2017 & III & ACC Proposal Skripsi \\
\hline 4 & 9 Maret 2017 & IV & Seminar Proposal \\
\hline 5 & 7 Juni 2017 & V & Bab I, II dan Bab III \\
\hline 6 & 2 Oktober 2017 & VI & Koreksi Bab I-V \\
\hline 7 & 9 Oktober 2017 & VII & Koreksi Bab I-V \\
\hline 8 & 16 Oktober 2017 & VIII & Koreksi Bab I-V \\
\hline 9 & 23 Oktober 2017 & IX & Koreksi Bab I-V \\
\hline 10 & 25 Oktober 2017 & X & Koreksi seluruh Skripsi \\
\hline 11 & 26 Oktober 2017 & XI & ACC Skripsi \\
\hline
\end{tabular}

Yogyakarta, 26 Oktober 2017

Pembimbing

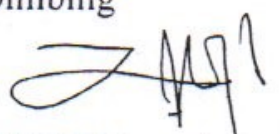

Dra. Wiji Hidayati, M.Ag

NIP. 196505231991032010 


\section{SURAT KETERANGAN \\ NOMOR :B. 527 UIN.02/TT/PP.09/10/2017}

Yang bertanda tangan di bawah ini, menerangkan dengan sesungguhnya bahwa :
Nama
NIM
: Arif Musafa
: 13490032
Fakultas
: Ilmu Tarbiyah dan Keguruan
Jurusan
: Manajemen Pendidikan Islam
Semester
: IX ( Sembilan )

Telah menyelesaikan semua beban SKS dengan :

Nilai C- sebanyak - ( Nihil) tanpa nilai E dan telah menyelesaikan tugas Praktek PPL I dan ( PPL- KKN Terintegrasi ).

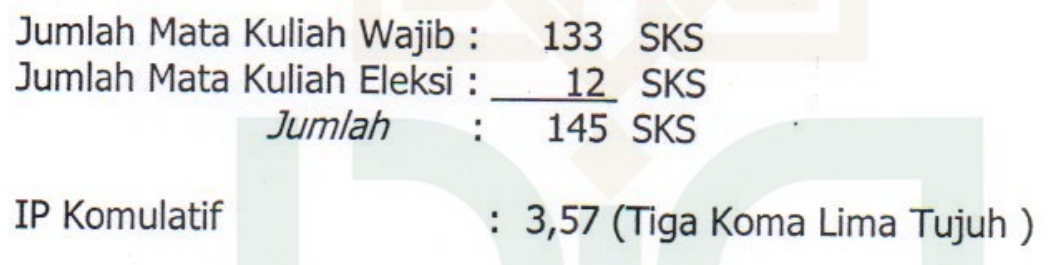

IP Komulatif

$$
\text { : 3,57 (Tiga Koma Lima Tujuh ) }
$$

Dan memenuhi persyaratan untuk mengikuti sidang munaqasyah.

Demikian agar dipergunakan sebagaimana mestinya.

Yogyakarta, 26 Oktober 2017

Kepala Bagian Tata Usaha

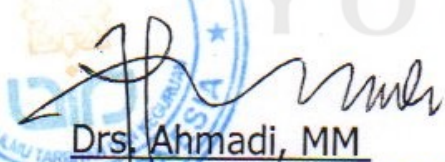

Drs Anmadi, MM

PLIK NIP. 196211121987031002
Petugas Pengecek Nilai

Jurusan Kependidikan Islam

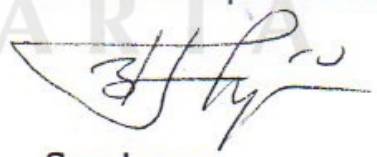

Supriyono

NIP. : 196002181992031001 


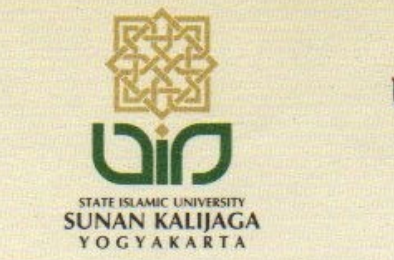

\section{KEMENTERIAN AGAMA \\ UNIVERSITAS ISLAM NEGERI SUNAN KALIJAGA FAKULTAS ILMU TARBIYAH DAN KEGURUAN}

Alamat: Jl. Marsda Adisucipto Telp. (0274) 513056 Fax. (0274) 519734 Website: http://tarbiyah.uin-suka.ac.id YOGYAKARTA 55281

\section{SERTIFIKAT}

Nomor : B.2065.b/Un.02/WD.T/PP.02/05/2016

Diberikan kepada

Nama

: ARIF MUSAFA

NIM

: 13490032

Jurusan/Prodi : Manajemen Pendidikan Islam

Nama DPL ～： Dr. Erni Munastiwi, M.Pd.

yang telah melaksanakan kegiatan Program Latihan Profesi I (PLP I)

di Kantor Lembaga Penjaminan Mutu Pendidikan Y̌ogyakarta dengan nilai:

\section{$97.00(\mathrm{~A})$}

Sertifikat ini diberikan sebagai bukti lulus PLP I sekaligus sebagai syarat untuk mengikuti Program Latihan Profesi II (PLP II).

Yogyakarta, 27 Mei 2016

a.n Wakil Dekan Fiuang Akademik

Ketua,

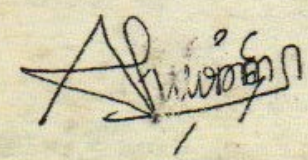

Adhi S tivawan, M.Pd. NIP. 198009012008011011 


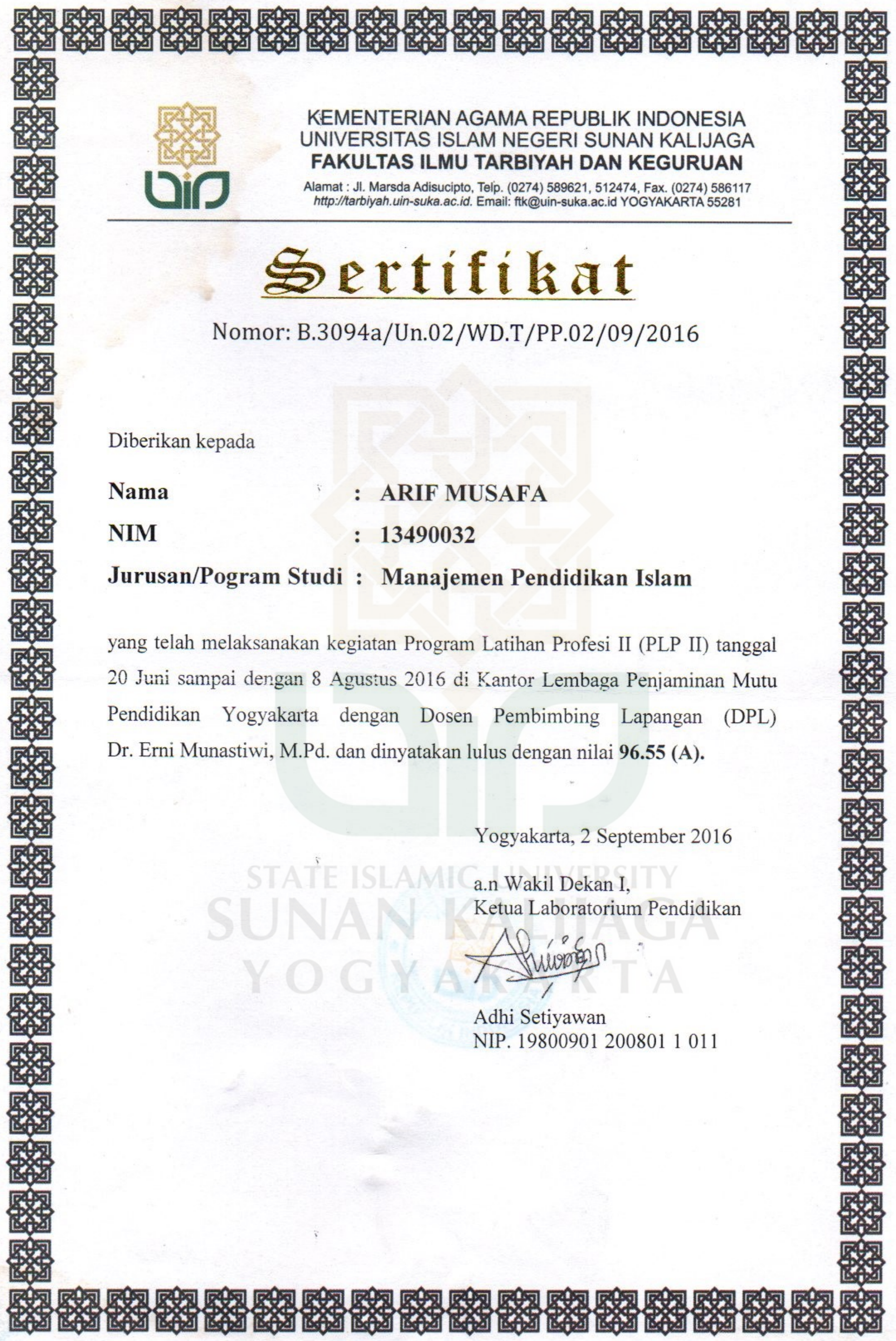




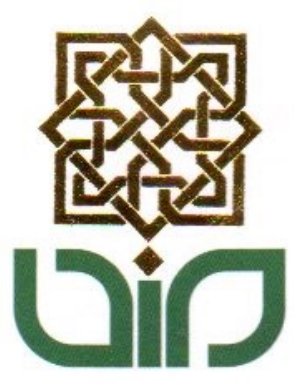

\section{KEMENTERIAN AGAMA \\ UNIVERSITAS ISLAM NEGERI SUNAN KALIJAGA \\ LEMBAGA PENELITIAN DAN \\ PENGABDIAN KEPADA MASYARAKAT (LP2M)}

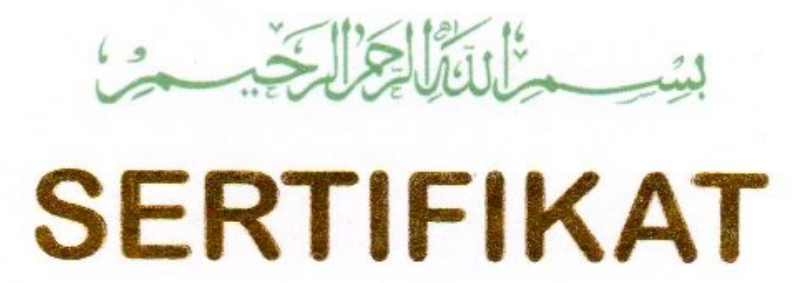

Nomor: B-420.1/UIN.02/L.3/PM.03.2/P5.470/12/2016

Lembaga Penelitian dan Pengabdian Kepada Masyarakat (LPPM) UIN Sunan Kalijaga memberikan sertifikat kepada:

$\begin{array}{ll}\text { Nama } & : \text { Arif Musafa } \\ \text { Tempat, dan Tanggal Lahir } & : \text { Cilacap, 02 Juni } 1995 \\ \text { Nomor Induk Mahasiswa } & : 13490032 \\ \text { Fakultas } & : \text { Ilmu Tarbiyah dan Keguruan }\end{array}$

yang telah melaksanakan Kuliah Kerja Nyata (KKN) Integrasi-Interkoneksi Semester Gasal, Tahun Akademik 2016/2017 (Angkatan ke-91), di:

$\begin{array}{ll}\text { Lokasi } & : \text { Putat Wetan, Putat } \\ \text { Kecamatan } & : \text { Patuk } \\ \text { Kabupaten/Kota } & : \text { Kab. Gunungkidul } \\ \text { Propinsi } & : \text { D.I. Yogyakarta }\end{array}$

dari tanggal 05 Juni s.d. 30 November 2016 dan dinyatakan LULUS dengan nilai 96,62 (A). Sertifikat ini diberikan sebagai bukti yang bersangkutan telah melaksanakan Kuliah Kerja Nyata (KKN) dengan status matakuliah intrakurikuler dan sebagai syarat untuk dapat mengikuti ujian Munaqasyah Skripsi.

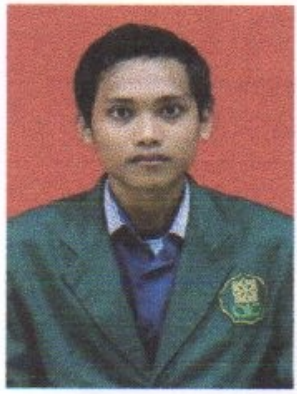

Yogyakarta, 05 Desember 2016

Ketua,

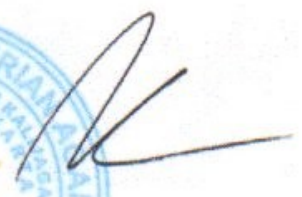

Dr. Phil. Al Makin, S.Ag., M.A.

NIP : 197209122001121002 

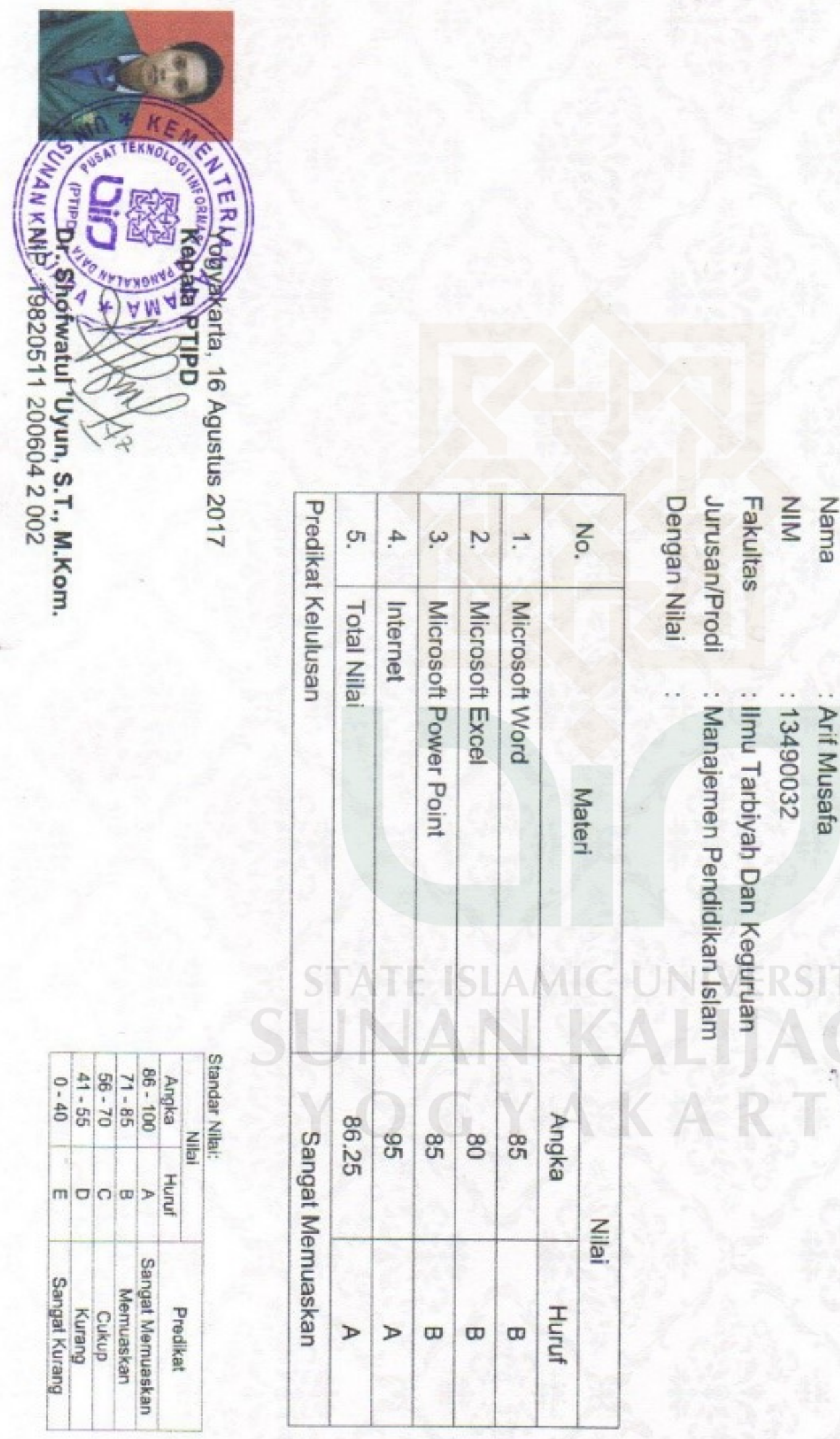


\section{سُّهادة

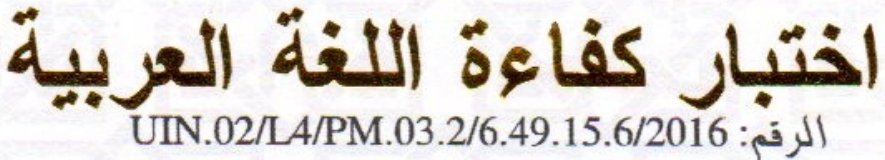

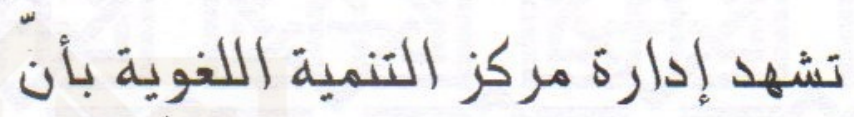

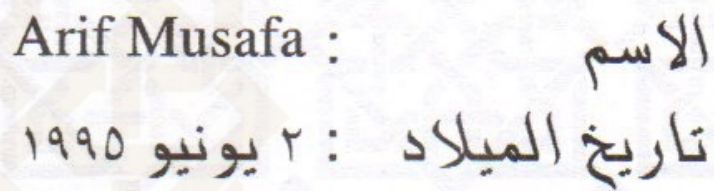

قد شارك في اختبار كفاءة اللغة العربية في با دبسمبر 17.r, وحصل

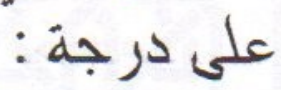

\begin{tabular}{|c|c|}
\hline $0 \varepsilon$ & فهم المسموع \\
\hline$\varepsilon \wedge$ & التراكيب النحوية و التعبيرات الكتابية \\
\hline 19 & فهم المقزوء \\
\hline EV & مجموع الدرجات \\
\hline
\end{tabular}

هذه الشهادة صالحة لمدة سنتين من تاريخ الإصدار

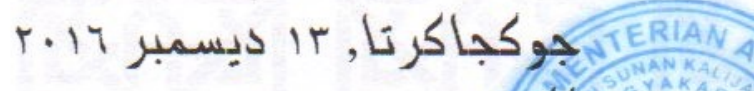

Dr. Sembodo Ardi Widodo, S.Ag., M.Ág.

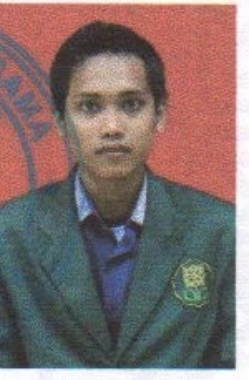

$$
\text { رقم التوظيف :01..0197101991.41 }
$$




\title{
TEST OF ENGLISH COMPETENCE CERTIFICATE
}

\author{
No: UIN.02/L4/PM.03.2/2.49.9.44/2016
}

Herewith the undersigned certifies that:

$\begin{array}{ll}\text { Name } & : \text { Arif Musafa } \\ \text { Date of Birth } & : \text { June 02,1995 } \\ \text { Sex } & : \text { Male }\end{array}$

took Test of English Competence (TOEC) held on November 04, 2016 by Center for Language Development of State Islamic University Sunan Kalijaga and got the following result:

\begin{tabular}{|l|c|}
\hline \multicolumn{2}{|c|}{ CONVERTED SCORE } \\
\hline Listening Comprehension & 41 \\
\hline Structure \& Written Expression & 44 \\
\hline Reading Comprehension & 43 \\
\hline Total Score & 427 \\
\hline
\end{tabular}

Validity: 2 years since the certificate's issued

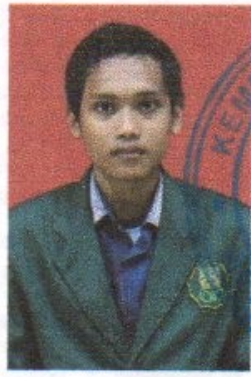
Yogyakarta, November 04,2016 Director,

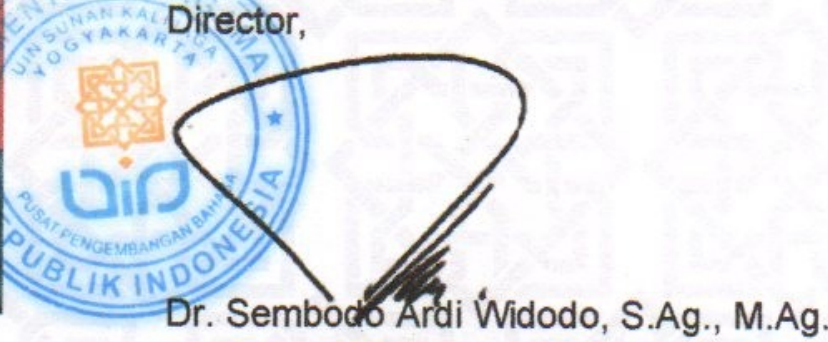

NIP. 196809151998031005 

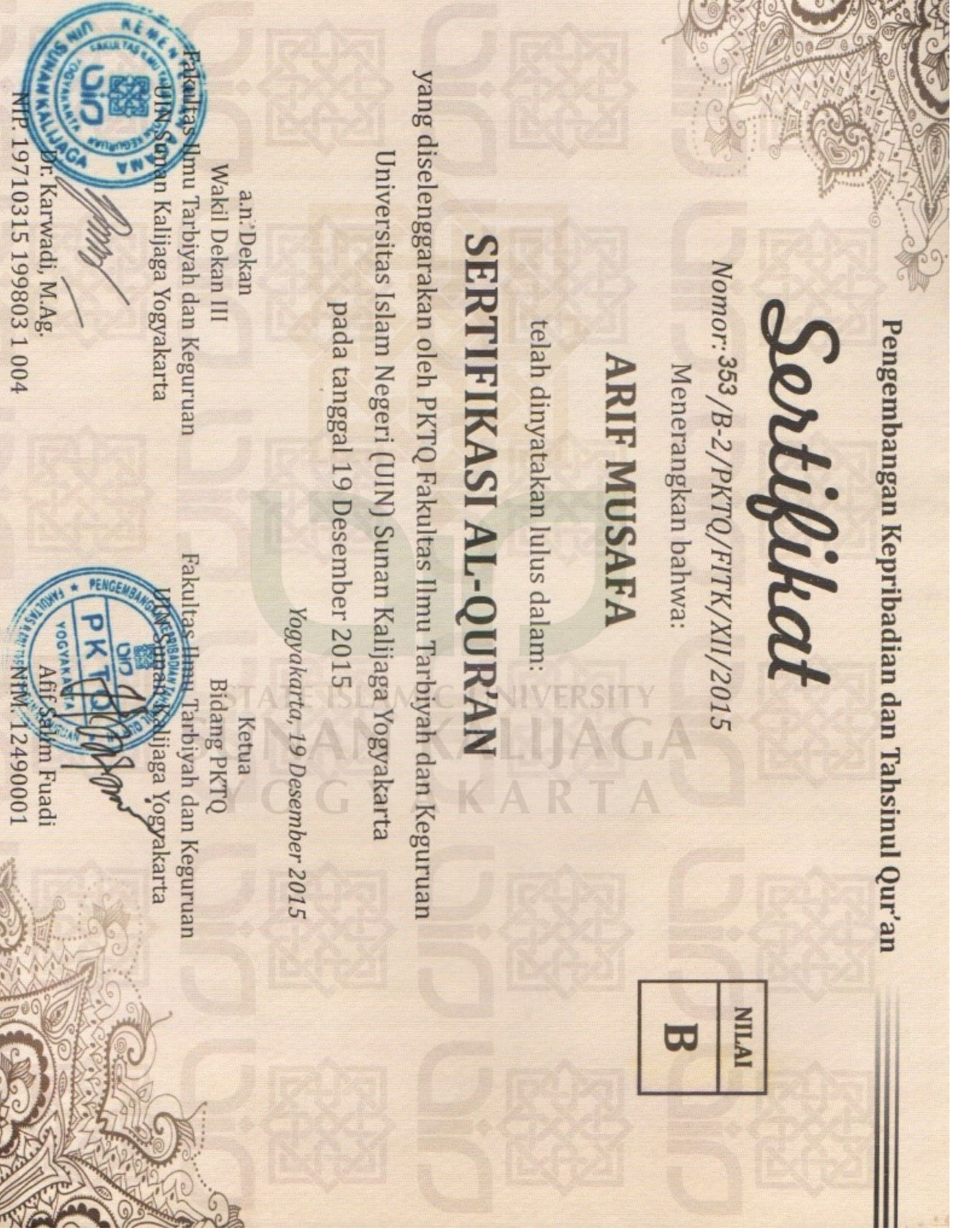

104. 0.9 .

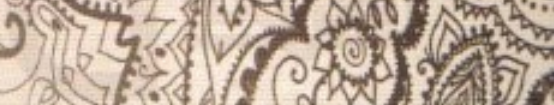

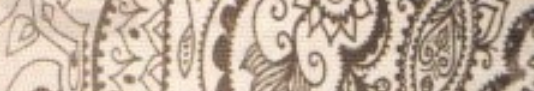

(1)
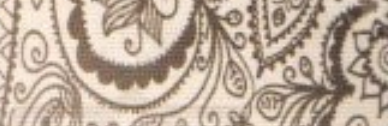


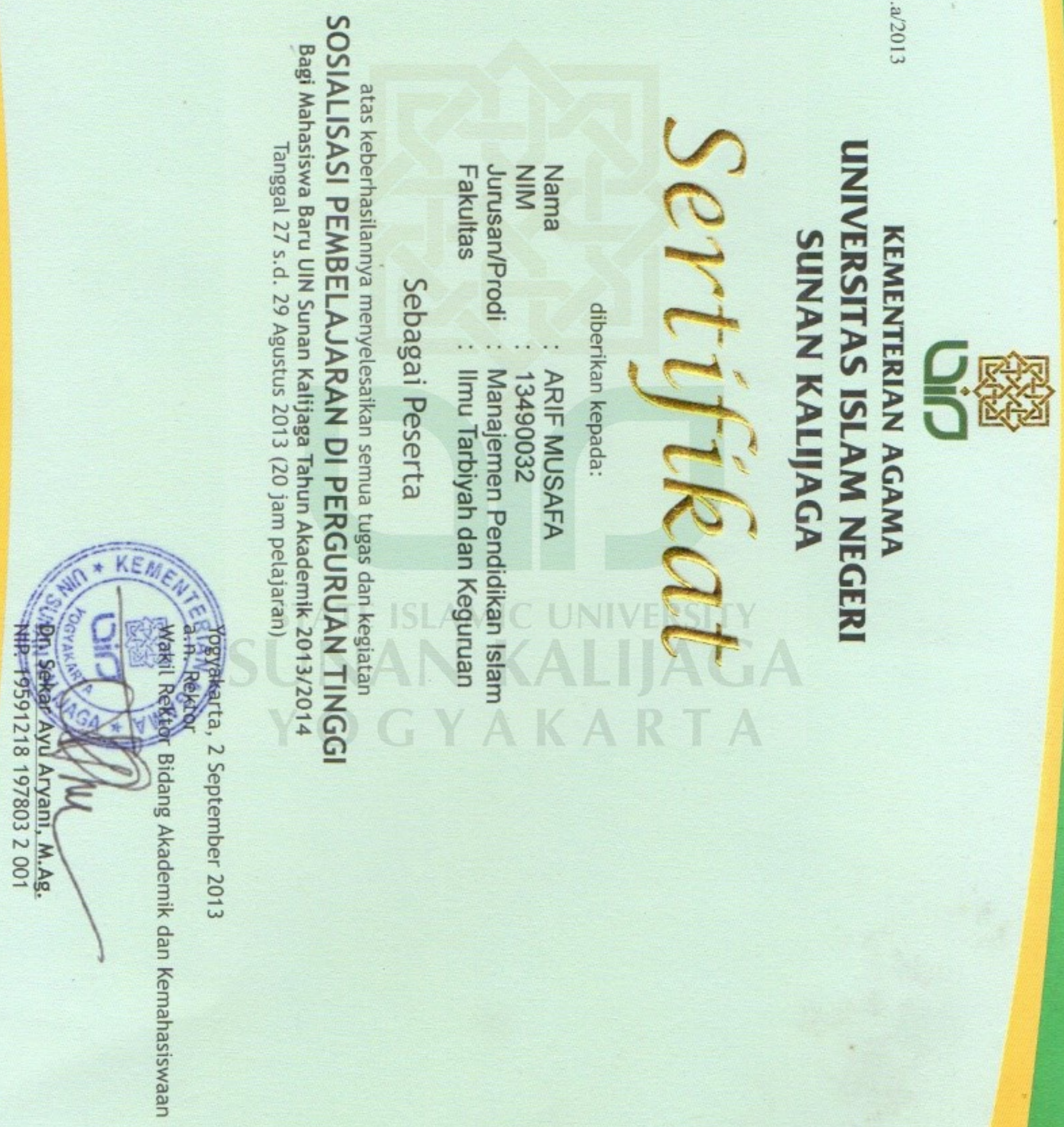




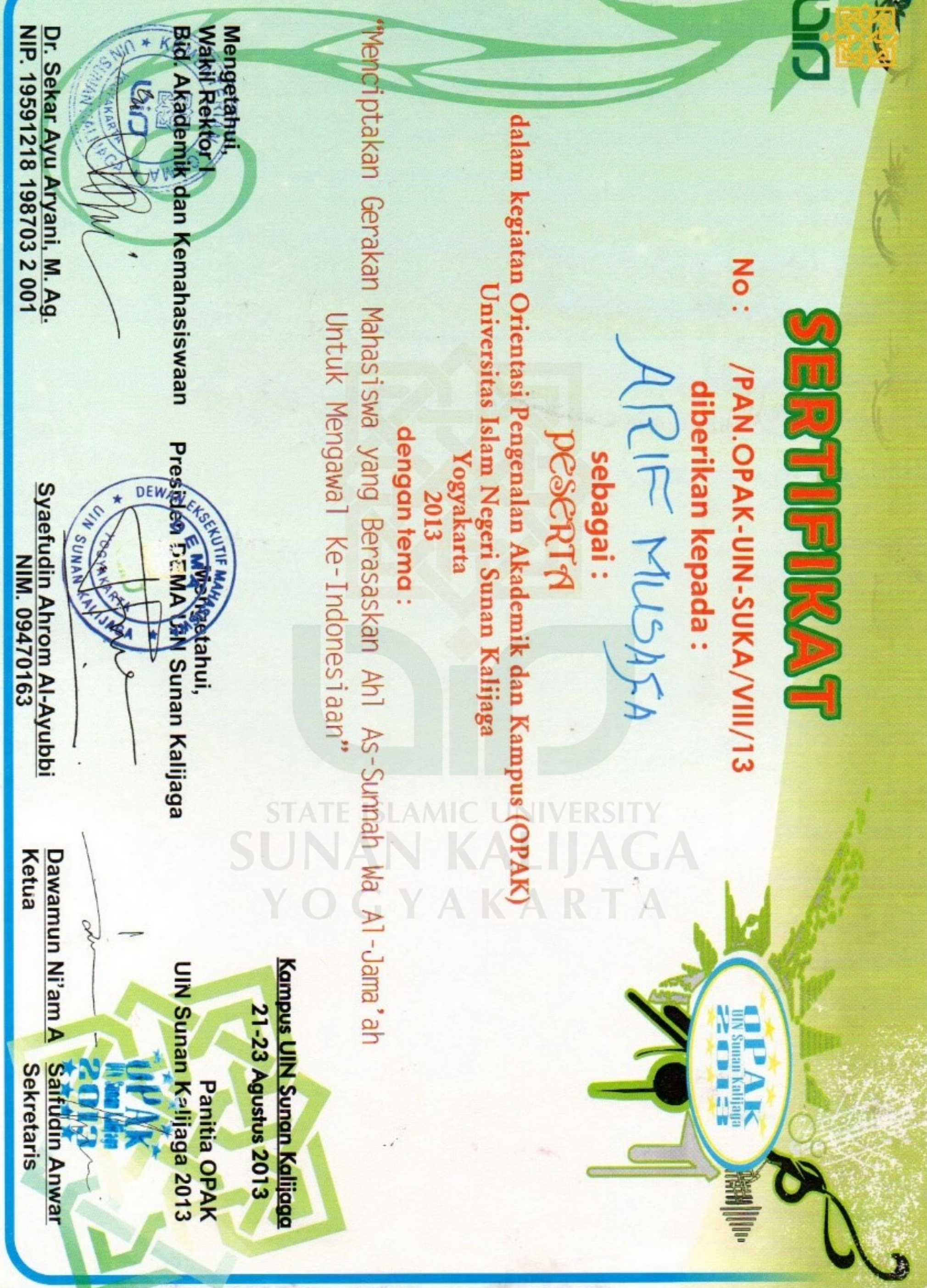


Foto Lokasi dan Kegiatan Santri Pesantren Al Qodir
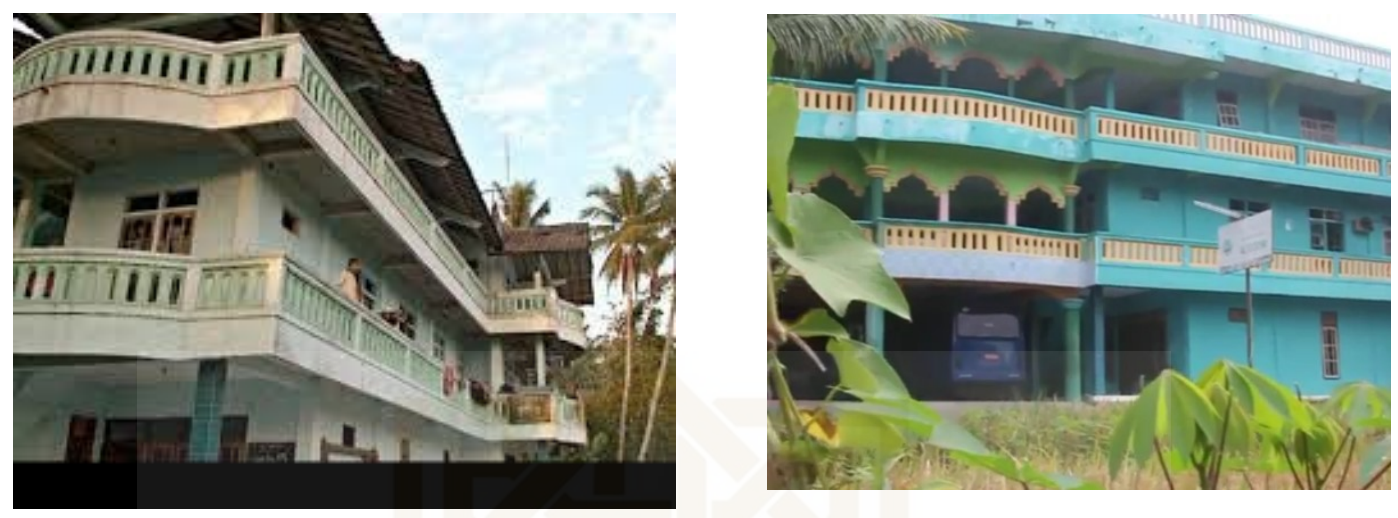

Gedung Pondok Pesantren Al Qodir
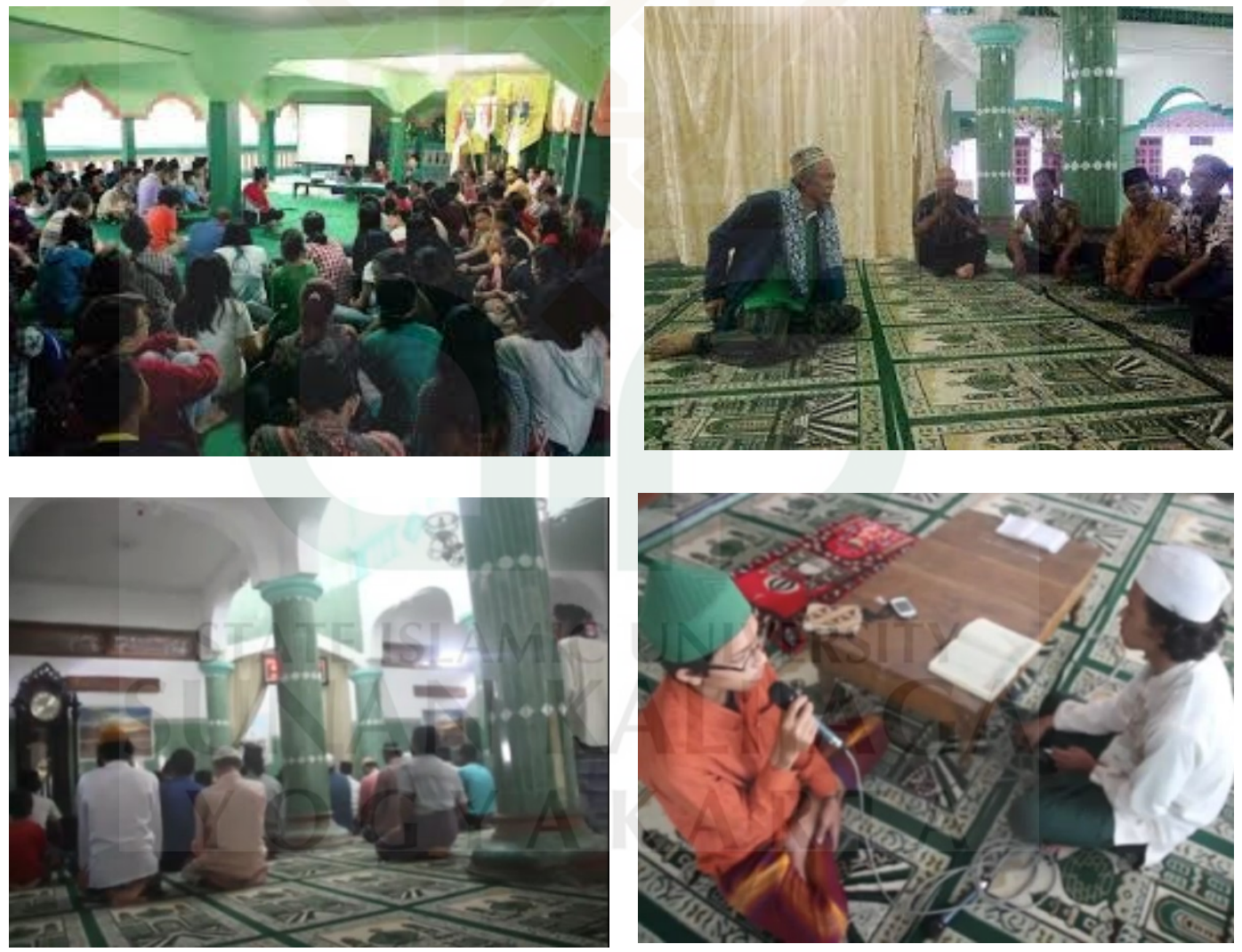

Kegiatan belajar mengajar pesantren Al Qodir 
Kegiatan santri pesantren Al Qodir
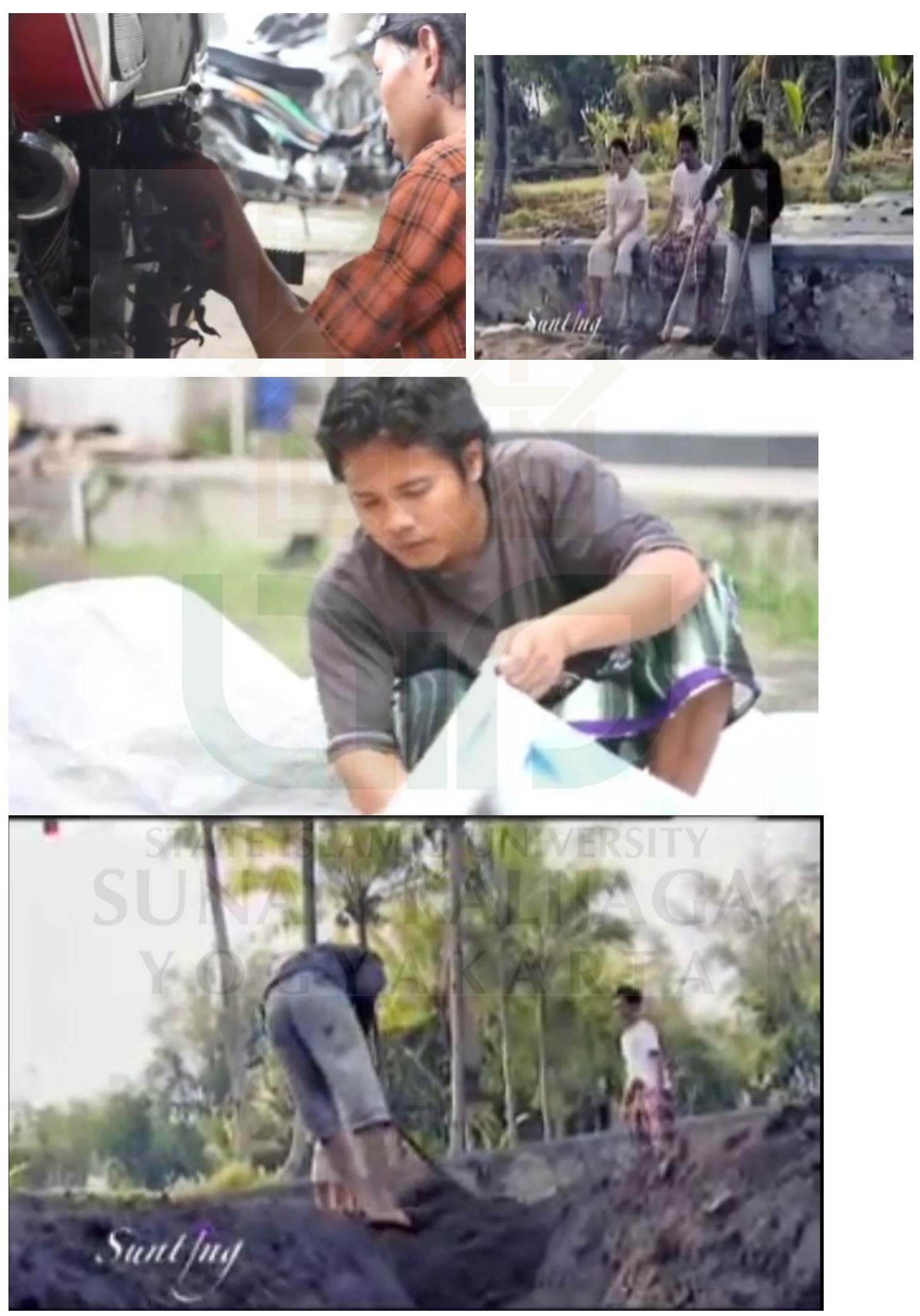
DATA PASIEN PUTRA TAHUN 2015-2017

\begin{tabular}{|l|l|l|l|l|l|l|}
\hline No & \multicolumn{1}{|c|}{ Nama Lengkap } & Tempat Lahir & Tanggal Lahir & \multicolumn{1}{|c|}{ Usia } & Mulai Mondok & \multicolumn{1}{|c|}{ Kelainan Psikis } \\
\hline 1 & Agus Hermawan & Bandung & & 44 Tahun & $9 / 24 / 2013$ & Gangguan Jiwa \\
\hline 2 & Muhammad Nur Ismail & Kulon Progo & $7 / 13 / 1977$ & 40 Tahun & $2 / 9 / 2014$ & Stress \\
\hline 3 & Agung Sulistiyanto & Boyolali & $1 / 21 / 1979$ & 38 Tahun & $3 / 23 / 2014$ & Stress \\
\hline 4 & M. Isa Ansari & Surabaya & $9 / 10 / 1974$ & 43 Tahun & $5 / 15 / 2014$ & Depresi \\
\hline 5 & Sutarman & Sleman & $1 / 1 / 1969$ & 48 Tahun & $5 / 17 / 2014$ & Depresi \\
\hline 6 & Bowo Laksono & Sleman & $1 / 31 / 1987$ & 30 Tahun & $7 / 22 / 2014$ & Narkoba \\
\hline 7 & Wagiyo & Wonosobo & $8 / 5 / 1976$ & 41 Tahun & $8 / 5 / 2014$ & Furqoh \\
\hline 8 & Duto Pratomo & Manado & $12 / 1 / 1979$ & 38 Tahun & $11 / 16 / 2014$ & Depresi \\
\hline 9 & Satya Wahyu R. & Klaten & $9 / 15 / 1976$ & 41 Tahun & $12 / 8 / 2014$ & Ketergantungan \\
\hline 10 & M. Bassam Reza Pahlevi & Pekalongan & $5 / 22 / 1992$ & 25 Tahun & $12 / 21 / 2014$ & Narkoba \\
\hline 11 & Firman Jufri & Jakarta & $10 / 30 / 1976$ & 41 Tahun & $1 / 1 / 2015$ & Narkoba \\
\hline 12 & Dariyanto & Semarang & $12 / 28 / 1962$ & 55 Tahun & $1 / 2 / 2015$ & Stress \\
\hline 13 & Sidik Pramono & Gunung Kidul & $1 / 1 / 1962$ & 55 Tahun & $3 / 24 / 2013$ & Stress \\
\hline 14 & Mahmud Faidzin & & & 17 tahun & $1 / 2 / 2015$ & Gangguan Jiwa \\
\hline 15 & Iwan & & & 17 tahun & $1 / 2 / 2015$ & Gangguan Jiwa \\
\hline 16 & Ahmad Hamidi Gufron & Kalianda & $2 / 5 / 1985$ & 32 Tahun & $4 / 4 / 2015$ & Stress \\
\hline 17 & Rizky Akbar & & & 17 tahun & $9 / 4 / 2015$ & Depresi \\
\hline 18 & Lukman Prayogi & Jakarta & $8 / 19 / 1988$ & 29 Tahun & $8 / 1 / 2015$ & Narkoba \\
\hline 19 & Baga Putra Pratama & Garut & $6 / 1 / 1991$ & 26 Tahun & $7 / 23 / 2015$ & Mondok \\
\hline 20 & Prihady Hastary & Palembang & & 17 tahun & $7 / 23 / 2005$ & Narkoba \\
\hline
\end{tabular}




\section{Curriculum Vitae}

1. Nama : Arif Musafa

2. No. Telp/HP : 0895362228636

3. Alamat Email : arifmusyaffa@gmail.Com

4. Tempat, Tgl Lahir : Cilacap, 02 Juni 2995

5. Program Studi : Manajemen Pendidikan Islam

6. Fakultas : Ilmu Tarbiyah Dan Keguruan

7. Agama : Islam

8. Alamat di Yogyakarta: Ambarrukmo, RT 05/02 Caturtunggal, Depok, Sleman.

9. Pendidikan : a. SD N Kutasari 04, Cipari, Cilacap

b. SMP Islam Caruy, Cipari, Cilacap

c. MAN Majenang, Cilacap

d. UIN Sunan Kalijaga Yogyakarta

10. Orang Tua
a. Ayah
: Poniman
b. Ibu
: Wahidah

11. Alamat Orang Tua : Jl. Moh. Hatta No. 41, Kutasari, Cipari, Cilacap

12. No Telp/Hp E IS : :089699856949

Yogyakarta, 7 Oktober 2017

Yang membuat

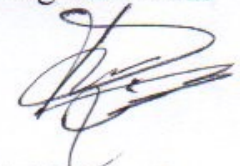

Arif Musafa 